DOE/EIA-0585(96)

Distribution Category UC-950

\title{
Alternatives to Traditional Transportation Fuels 1996
}

\author{
December 1997
}

Energy Information Administration

Office of Coal, Nuclear, Electric and Alternate Fuels

U.S. Department of Energy

Washington, DC 20585

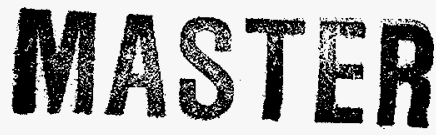

This report was prepared by the Energy Information Administration, the independent statistical and analytical agency within the U.S. Department of Energy. The information contained herein should be attributed to the Energy Information Administration and should not be construed as advocating or reflecting any policy position of the Department of Energy or of any other organization. 


\section{Contacts}

This report was prepared by the Energy Information Administration (EIA), Office of Coal, Nuclear, Electric and Alternate Fuels. General information about this document may be obtained from the National Energy Information Center (202/586-8800). Further information about the report may be obtained from Fred Mayes (202/426-1166), Chief of the Renewable Energy Branch. Questions concerning alternative-fueled vehicles in use and fuel consumption may be referred to Mary Joyce (202/426-1168) or Jorge Luna-Camara (202/426-1170). Questions concerning the EIA-886 survey, "Alternative Fuel Vehicle Suppliers' Annual Report," may be directed to Chris Buckner (202/426-1167). 


\section{DISCLAIMER}

This report was prepared as an account of work sponsored by an agency of the United States Government. Neither the United States Government nor any agency thereof, nor any of their employees, make any warranty, express or implied, or assumes any legal liability or responsibility for the accuracy, completeness, or usefulness of any information, apparatus, product, or process disclosed, or represents that its use would not infringe privately owned rights. Reference herein to any specific commercial product, process, or service by trade name, trademark, manufacturer, or otherwise does not necessarily constitute or imply its endorsement, recommendation, or favoring by the United States Government or any agency thereof. The views and opinions of authors expressed herein do not necessarily state or reflect those of the United States Government or any agency thereof. 


\section{DISClatmiex}

Portions of this doement may be illegible in electronic insage produets. Images are produced from the best available original document. 


\section{Contents}

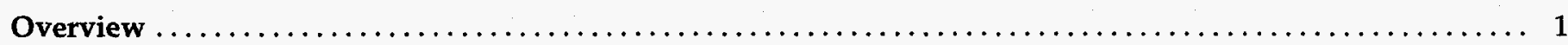

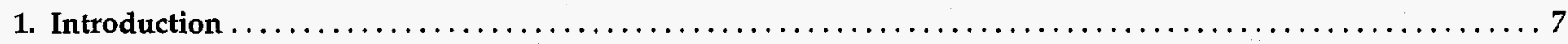

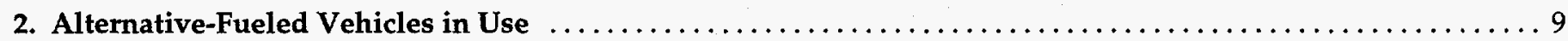

Trends in Alternative-Fueled Vehicles, by Fuel Type $\ldots \ldots \ldots \ldots \ldots \ldots \ldots \ldots \ldots \ldots \ldots \ldots \ldots \ldots \ldots$

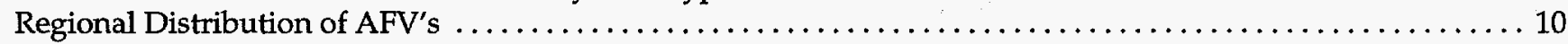

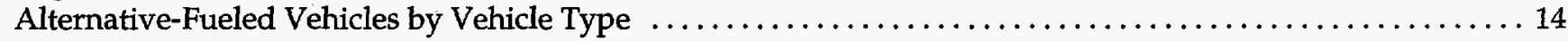

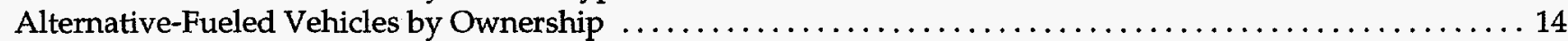

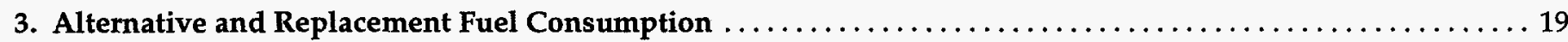

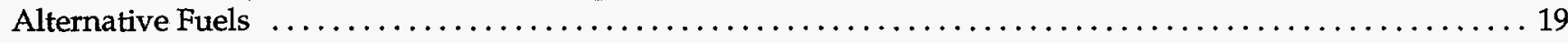

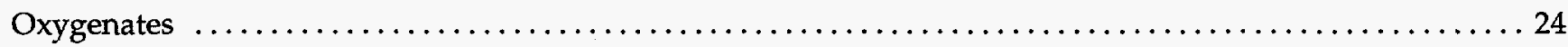

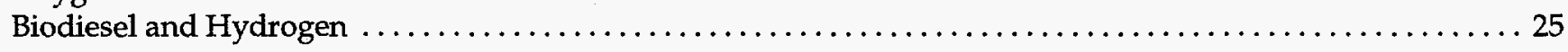

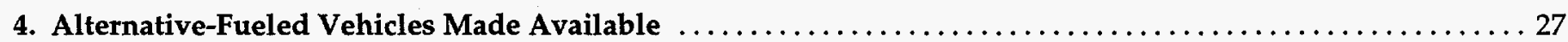

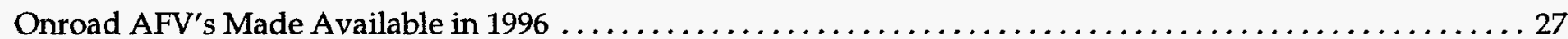

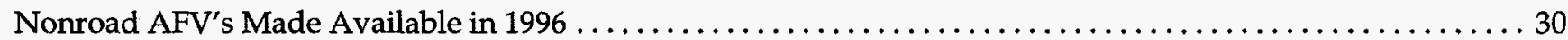

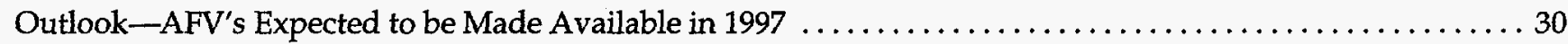

\section{Appendices}

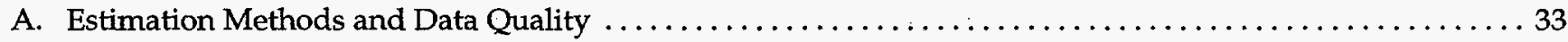

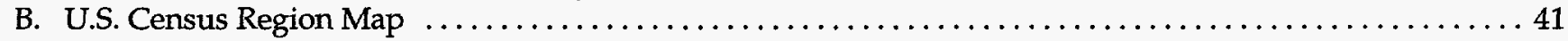

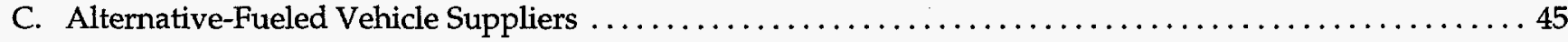

D. Alternative-Fueled Vehicles Made Available in 1995, Revised ........................ 59

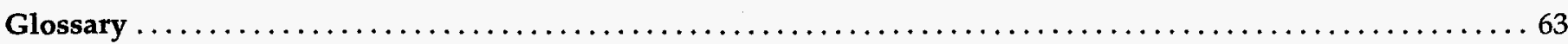


1. Estimated Number of Alternative-Fueled Vehicles in Use in the United States, by Fuel, 1992-1998 . . ...... 9

2. Estimated Number of Alternative-Fueled Vehicles in Use in the United States, by Fuel and Census Region, 1996-1998

3. Estimated Number of Alternative-Fueled Vehicles in Use, by State, 1996-1998 $\ldots$

4. Estimated Number of Alternative-Fueled Vehicles in Use, by State and Fuel Type, $1996 \ldots \ldots \ldots \ldots \ldots \ldots 13$

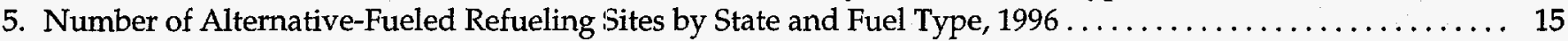

6. Estimated Number of Alternative-Fueled Vehicles in Use in the United States, by Fuel and Weight Category,

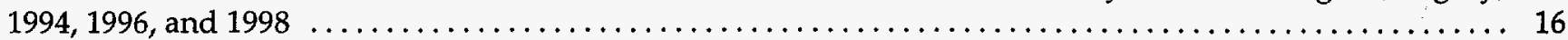

7. Estimated Number of Alternative-Fueled Vehicles in Use by U.S. Private Entities, by Fuel and Weight Category, 1994, 1996, and 1998

8. Estimated Number of Alternative-Fueled Vehicles in Use by State and Local Governments, by Fuel and

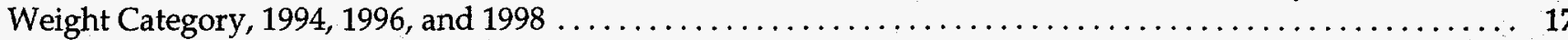

9. Estimated Number of Alternative-Fueled Vehicles in Use by the U.S. Federal Government, by Fuel and

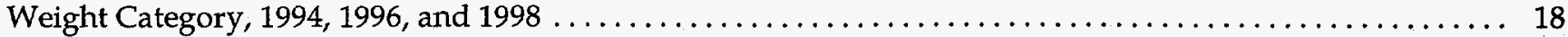

10. Estimated Consumption of Vehicle Fuels in the United States, $1992-1998 \ldots \ldots \ldots \ldots \ldots \ldots \ldots \ldots \ldots \ldots . \ldots \ldots$

11. Estimated Share of Alternative Transportation Fuel Consumption, by Region, 1996-1998 ............ 21

12. Estimated Consumption of Alternative Transportation Fuels in the United States, by Fuel and Vehicle Weight, 1994, 1996, and 1998

13. Estimated Consumption of Alternative Transportation Fuels in the United States, by Vehicle Ownership, 1994, 1996, and 1998

14. Number of Onroad Alternative-Fueled Vehicles Made Available, by Fuel Type and Vehicle Configuration, 1996

15. Number of Nonroad Alternative-Fueled Vehicles Made Available in 1996, and Planned to Made Available

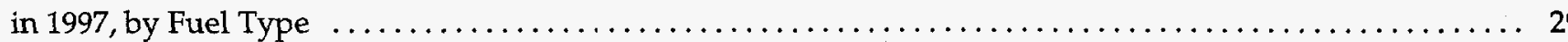

16. Number of Onroad Alternative-Fueled Vehicles Made Available, by Fuel Type, 1994-1996 . . .......... 29

17. Number of Onroad Alternative-Fueled Vehicles Planned to be Made Available, by Fuel Type and Vehicle

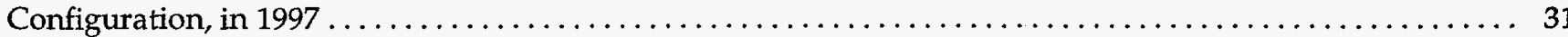

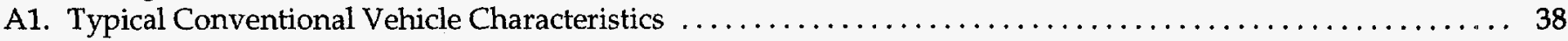

A2. Original and Adjusted Lower Heating Values of Conventional and Replacement Fuels . . . . . . . . . . . 39

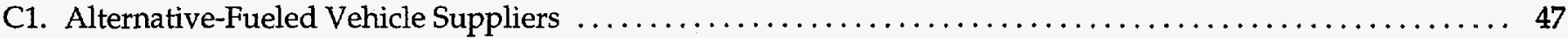

D1. Number of Onroad Alternative-Fueled Vehicles Made Available, by Fuel Type and Vehicle Configuration in

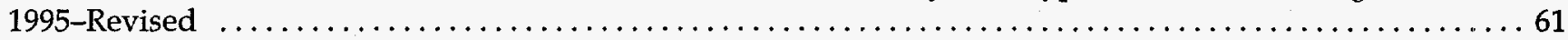

D2. Number of Nonroad Alternative-Fueled Vehicles Made Available in 1995, by Fuel Type-Revised . ......62 62

\section{Figures}

1. Estimated Number of Alternative-Fueled Vehicles in Use in the United States, 1992-1998 . . . . . . . . ... 1

2. States with the Largest Number of Alternative-Fueled Vehicles in Use, $1996 \ldots \ldots \ldots \ldots \ldots \ldots \ldots \ldots \ldots \ldots$

3. Estimated Shares of Alternative-Fueled Vehicles in Use in the United States by Fuel Type, 1992-1996 ... ... 2

4. Alternative-Fueled Vehicle Types in Use by Ownership Classification, $1996 \ldots \ldots \ldots \ldots \ldots \ldots \ldots \ldots \ldots \ldots 2$

5. Estimated Consumption of Vehicle Fuels in the United States by Fuel Type, 1992-1998 . . . . . . . . . . . 3

6. Estimated Consumption of Oxygenates and Alternative Fuels in the United States by Fuel Type, 1992-1998 .. 3

7. Census Region Shares of Estimated Total U.S. Consumption of Alternative Fuels by Fuel Type, 1996 . . . . . . 4 4

8. Estimated Consumption of Alternative Fuels in the United States by Vehicle Type, 1994, 1996, and 1998 .... 4

9. Onroad Alternative-Fueled Vehicles Made Available in the United States by Fuel Type, $1996 \ldots \ldots \ldots . \ldots 5$

10. Onroad Alternative-Fueled Vehicles Made Available in the United States by Fuel Type and Vehicle

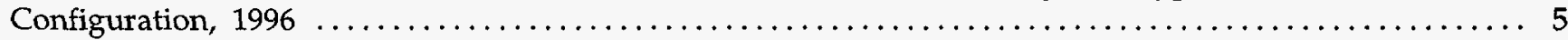

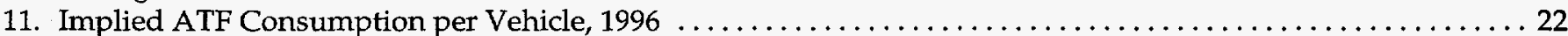

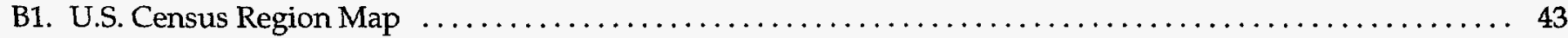




\section{Overview}

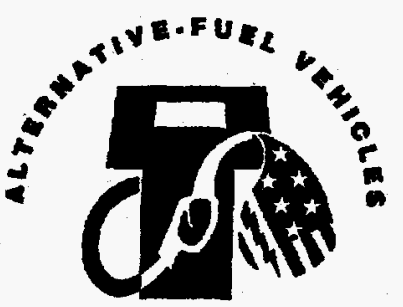

This report presents data on U.S. alternative-fueled vehicles ( $A F V^{\prime}$ 's). The alternative transportation fuels $\left(A T F^{\prime}\right.$ 's) considered are compressed natural gas (CNG), liquefied natural gas (LNG), liquefied petroleum gas (LPG-i.e., propane), methanol and ethanol blends (e.g., M85, E85), electricity, and neat biodiesel.

\section{Alternative-Fueled Vehicles in Use}

Figure 1. Estimated Number of Alternative-Fueled Vehicles in Use in the United States, 1992-1998

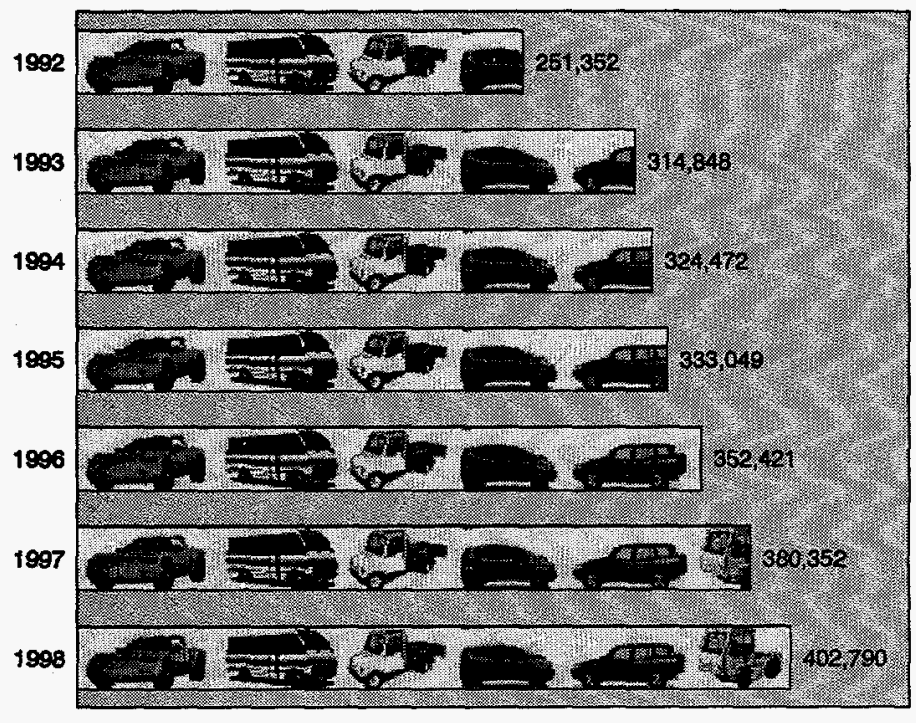

More than 352,000 AFV's were in use in the United States in 1996, a 40-percent increase since 1992.

Another 50,000 AFV's are expected to be in use in the United States by the end of 1998.

Source: Table 1, page 9.

Figure 2. States with the Largest Number of Alternative-Fueled Vehicles in Use, 1996

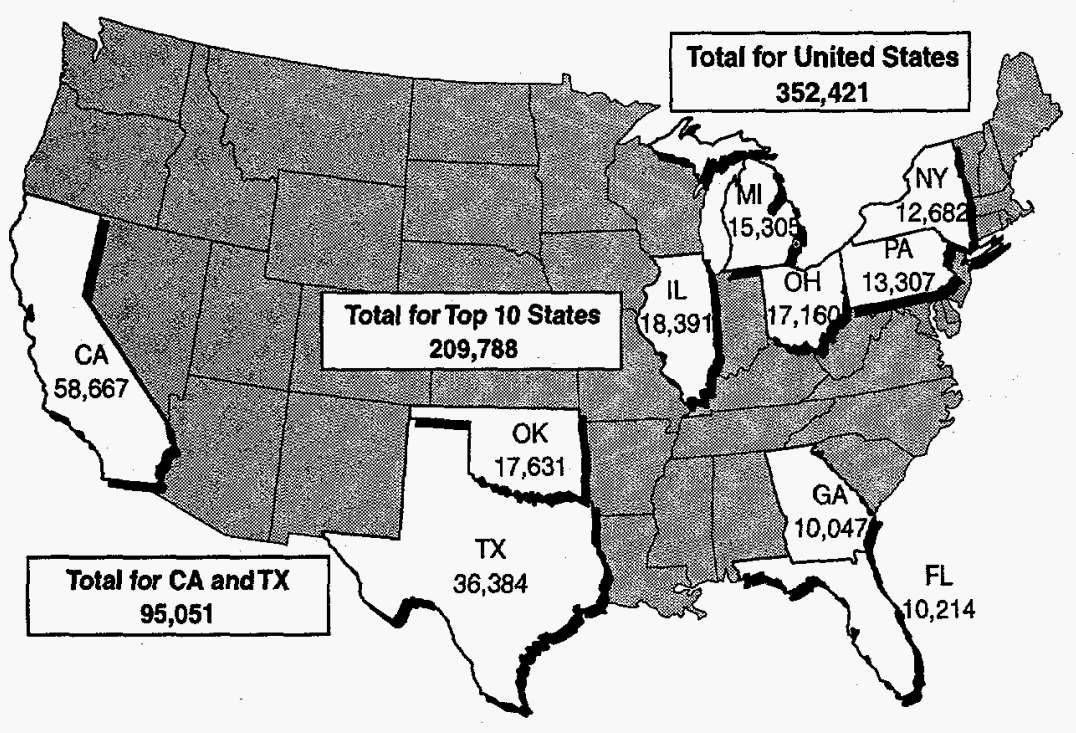

In 1996, 10 States had more than 10,000 AFV's in use.

More than one-fourth of the AFV's in use are in California and Texas. 


\section{Alternative-Fueled Vehicles in Use}

Figure 3. Estimated Shares of Alternative-Fueled Vehicles in Use in the United States by Fuel Type, 1992-1996

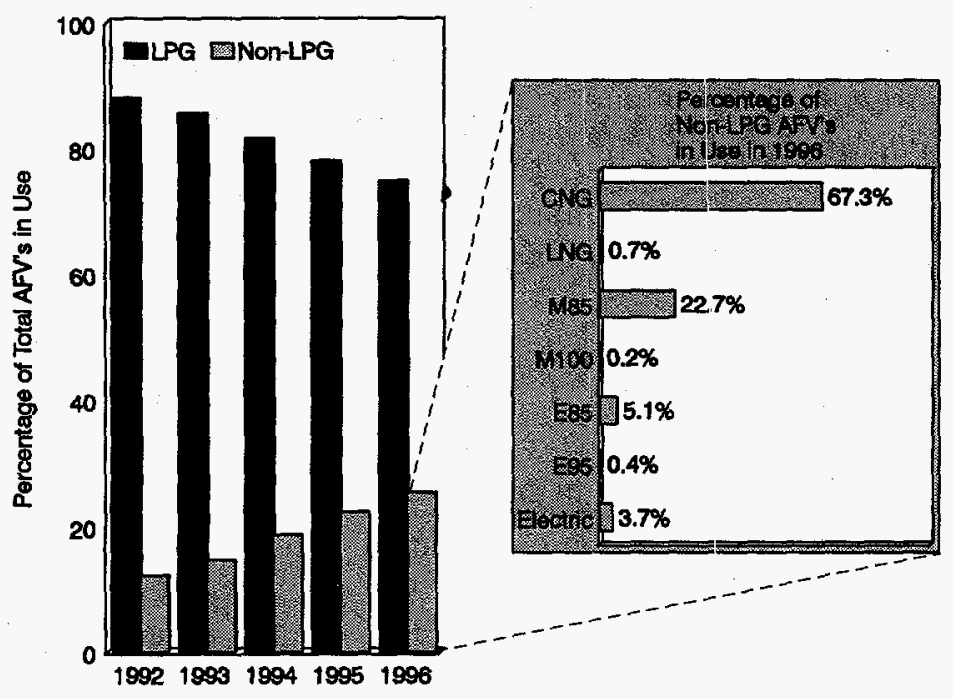

- Three-fourths of the AFV's in use in 1996 were designed to operate on liquefied petroleum gas (LPG), primarily propane.

- Of the non-LPG AFV's in use in 1996, two-thirds were fueled by natural gas-primarily by compressed natural gas (CNG) and a smaller number by liquefied natural gas (LNG).

Source: Table 1, page 9.

Figure 4. Alternative-Fueled Vehicle Types in Use by Ownership Classification, 1996

More than two-thirds of the AFV's in use in the United

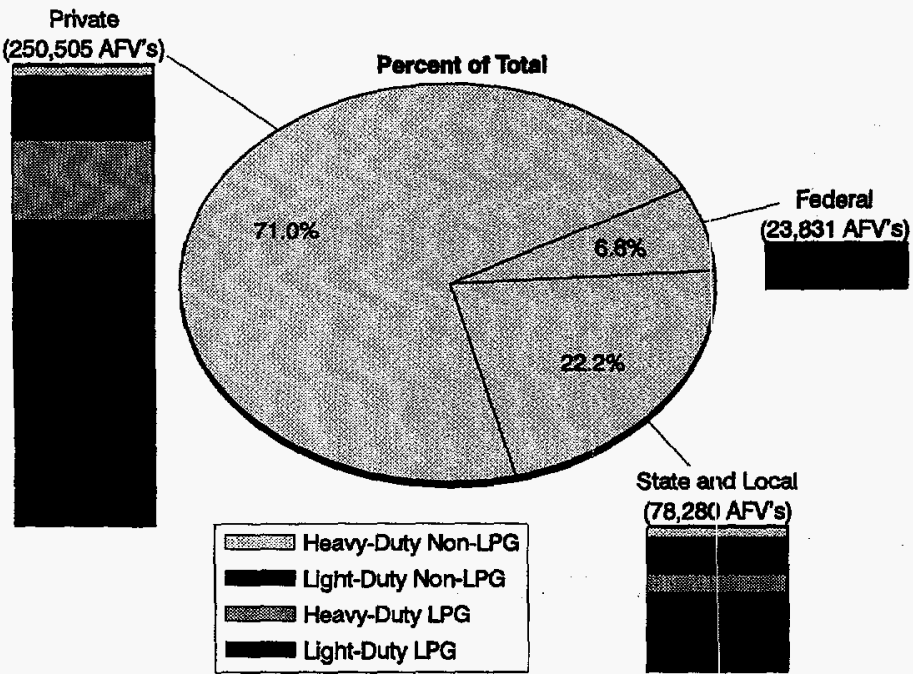

States in 1996 were privately owned.

wore than 80 percent of privately owned AFV's are light-duty vehicles fueled with LPG.

* Nearly all federally owned AFV's are light-duty non-LPG vehicles. 
Consumption of Alternative and Replacement Fuels

Figure 5. Estimated Consumption of Vehicle Fuels in the United States by Fuel Type, 1992-1998

* Although traditional fuels continue to dominate U.S.

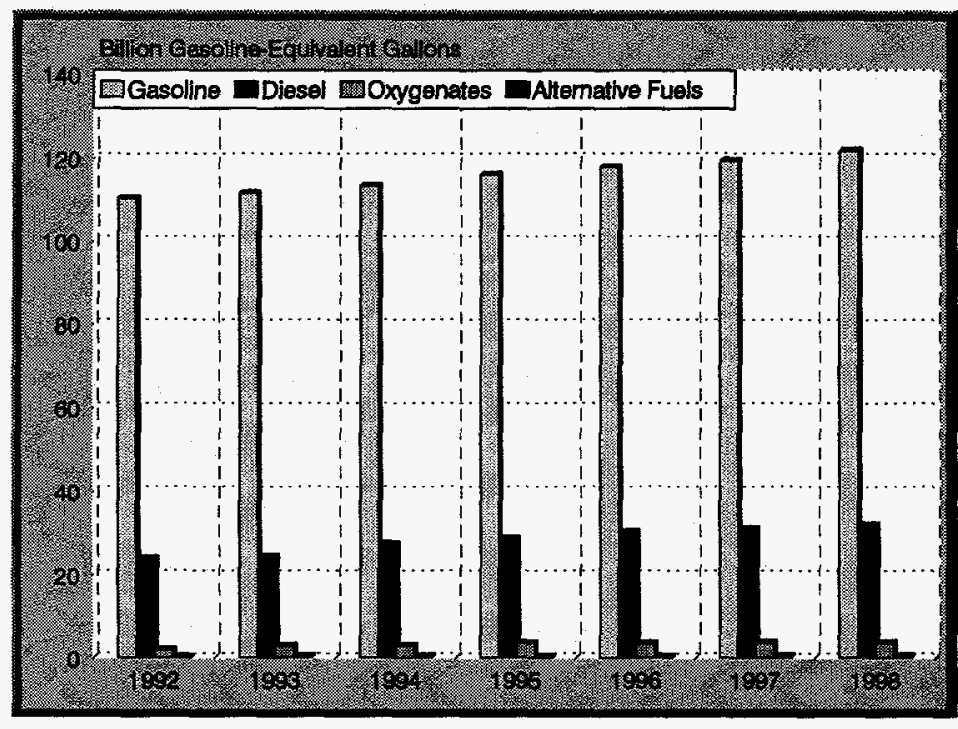
vehicle fuel use, consumption of alternative and replacement fuels (including oxygenates) is growing rapidly.

- From 1992 to 1996, consumption of alternative and replacement fuels (measured in gasolineequivalent gallons) increased by 76 percent.

- From 1996 to 1998, consumption of replacement and alternative fuels is expected to increase by about 9 percent.

Source: Table 10, page 20.

Figure 6. Estimated Consumption of Oxygenates and Alternative Fuels in the United States by Fuel Type, 1992-1998

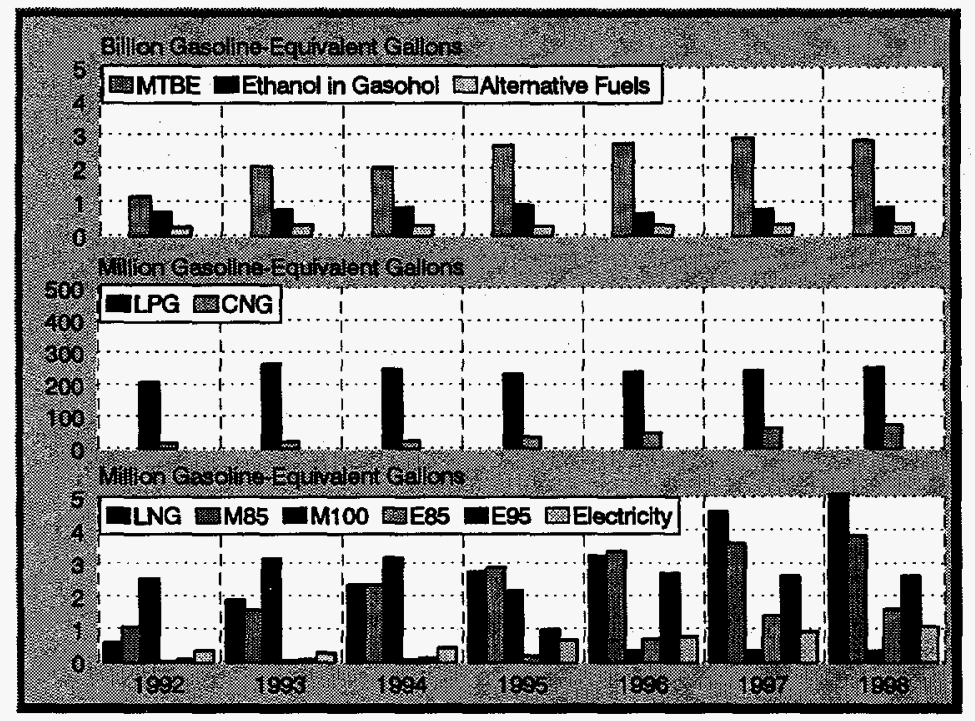

Consumption of the oxygenates methyl tertiary butyl ether (MTBE) and ethanol in gasoline blends accounted for more than 90 percent of the total use of alternative and replacement fuels in 1996.

- Continued rapid growth is expected for consumption of alternative fuels. 
Figure 7. Census Region Shares of Estimated Total U.S. Consumption of Alternative Fuels by Fuel Type, 1996

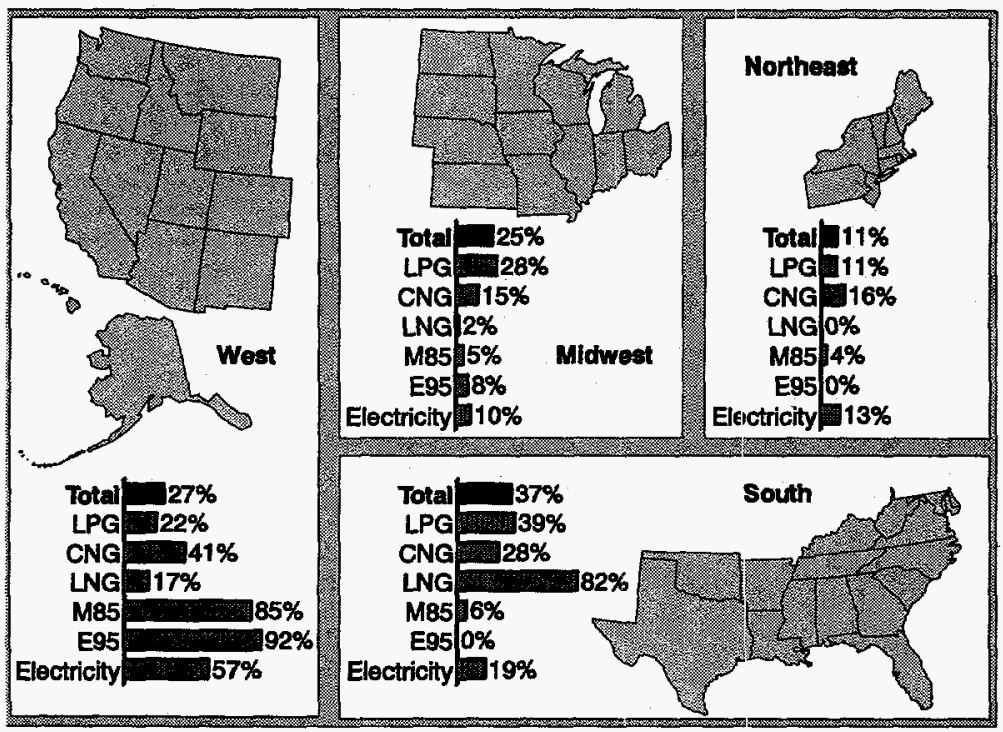

- Of the four U.S. Census regions, the South-which includes the State of Texas-was the largest consumer of alternative fuels in 1996.

- Consumption shares for individual alternative fuel types vary among the regions, with the West using the most M85 and electricity and the South using the most LNG.

Source: Table 11, page 21.

Figure 8. Estimated Consumption of Alternative Fuels in the United States by Vehicle Type, 1994, 1996, and 1998

- U.S. consumption of alternative

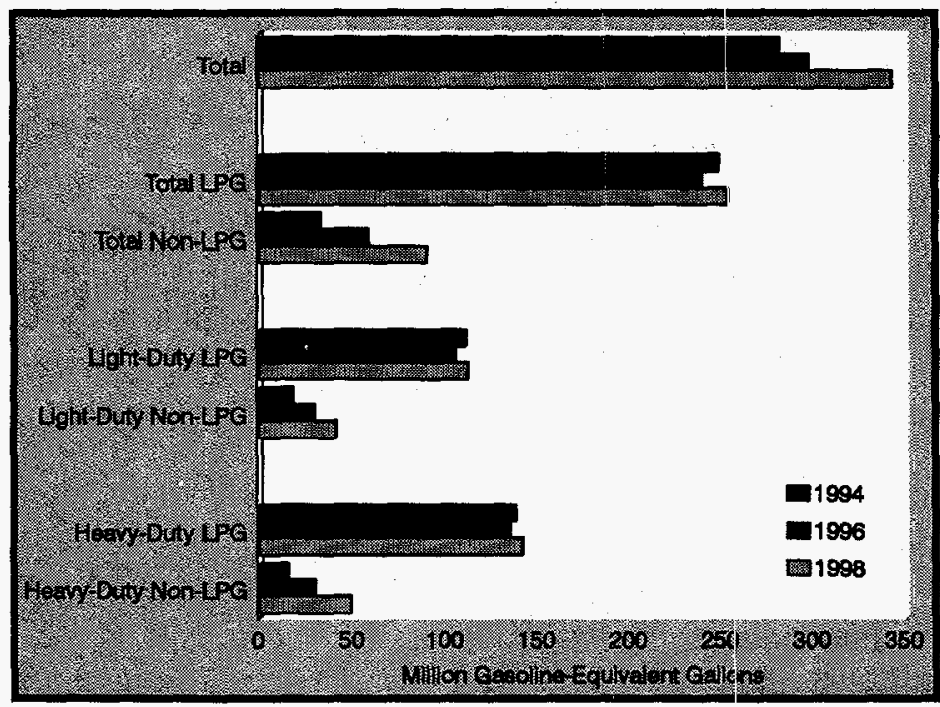
fuels is expected to grow by more than 45 million gasolineequivalent gallons between 1996 and 1998, compared with an increase of about 16 million gallons from 1994 to 1996.

* The fastest growth in alternative fuel consumption from 1994 to 1998 is expected for heavy-duty non-LPG vehicles. 
Alternative-Fueled Vehicles Made Available

Figure 9. Onroad Alternative-Fueled Vehicles Made Available in the United States by Fuel Type, 1996

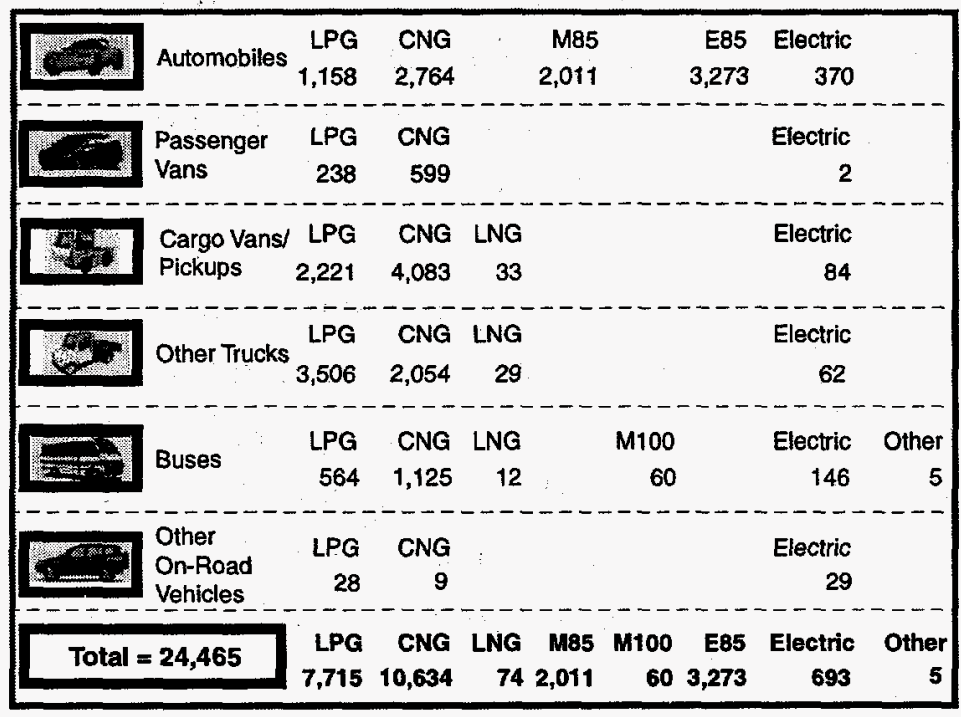

An estimated total of 24,465 onroad alternative-fueled vehicles were made available in the United States during 1996.

- About 40 percent of the onroad AFV's made available were automobiles, and nearly half were cargo vans, pickups, or other trucks.

- More than half the onroad AFV's made available in 1996 were natural gas or alcoholfueled vehicles. More than 30 percent were LPG vehicles.

Source: Table 14, page 28 .

Figure 10. Onroad Alternative-Fueled Vehicles Made Available in the United States by Fuel Type and Vehicle Configuration, 1996

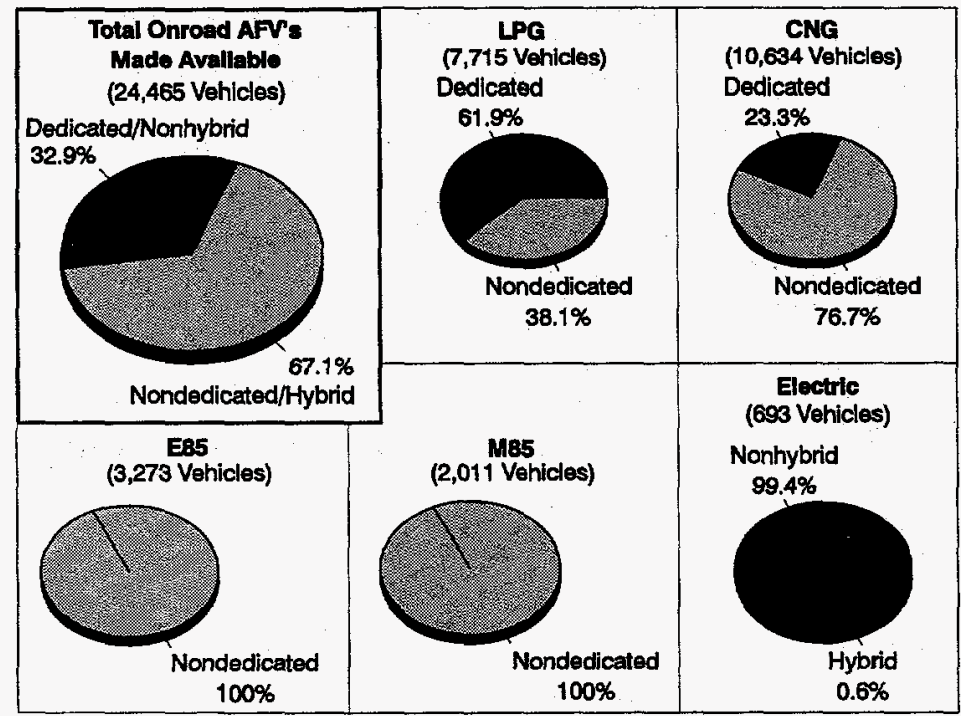

Only about one-third of the onroad AFV's made available during 1996 were dedicated (single-fueled) vehicles.

All the M85- and E85-fueled vehicles made available were nondedicated-configured to use either alternative or conventional fuels. 



\section{Introduction}

Interest in the alternative transportation fuels $\left(\mathrm{ATF}^{\prime} \mathrm{s}\right)^{1}$ has increased in recent years due to the drives for cleaner air and less dependence upon foreign oil. This report, Alternatives to Traditional Transportation Fuels 1996, provides information on ATF's, as well as the vehicles that consume them.

This report has its roots in Section 503 of the Energy Policy Act of 1992 (EPACT), which directs the Energy Information Administration (EIA) to provide the U.S. Department of Energy (DOE) and the Congress with the following information on alternative-fueled vehicles $\left(A F{ }^{\prime}\right)^{2}$ and ATF's:

- The number, type, and geographic distribution of AFV's in use (Chapter 2)

- The consumption of ATF's and "replacement fuels"3 (Chapter 3)

- The number and type of AFV's "made available" (Chapter 4).

Section 503 further specifies that information about these subjects is to be provided annually for the "current" and "following" years; i.e., the most recent historical year and an outlook for the next year. Since EPACT was passed in response to concerns about energy security (occasioned by the 1991 Persian Gulf conflict), its focus is on energy efficiency and improving domestic energy supplies. Clean air data and issues related to transportation fuels (except for requiring DOE to report on the greenhouse gas emissions resulting from ATF consumption) are addressed in the Clean Air Act Amendments of 1990 and are not discussed in this report.

In addition to the information described above, this report includes:

- A discussion of the methodology used to develop the estimates, including a discussion of the survey Form EIA-886, "Alternative Fuel Vehicle Suppliers' Annual Report" (Appendix A)

- A map defining geographic regions used (Appendix B)

- A list of AFV suppliers (Appendix C)

- Revised AFV "made available" information for the calendar year 1995 (Appendix D).

The ATF's considered in this report are compressed natural gas (CNG), liquefied natural gas (LNG), liquefied petroleum gas (LPG, i.e. propane), methanol, ethanol, electricity, and neat biodiesel. ${ }^{4}$ Vehicles consuming these fuels may either be "new" AFV's or existing vehicles with converted fuel systems.

This report is EIA's fourth annual report on alternative transportation fuels. EIA produced its first report on AFV's and ATF's in 1994..$^{5}$ It contains extensive background material on ATF and AFV characteristics, legislation, and industry-related information, as well as

1 Section 301 of EPACT defines "alternative fuels" as: methanol, denatured ethanol, and other alcohols; mixtures containing 85 percent or more (or such other percentage, but not less than 70 percent, as determined by the Secretary of Energy, by rule, to provide for requirements relating to cold start, safety, or vehicle functions) by volume of methanol, denatured ethanol, and other alcohols with gasoline or other fuels; natural gas; liquefied petroleum gas; hydrogen; coal-derived liquid fuels; fuels (other than alcohol) derived from biological materials; electricity (including electricity from solar energy); and any other fuel the Secretary determines, by rule, is substantially not petroleum and would yield substantial energy security benefits and substantial environmental benefits.

2 An alternative-fueled vehicle is defined as a vehicle either designed and manufactured by an original equipment manufacturer or a converted vehicle designed to operate in either dual-fuel, flexible-fuel, bi-fuel, or dedicated modes on fuels other than gasoline or diesel. This does not include a conventional vehicle that is limited to operation on blended or reformulated gasoline.

3 EPACT defines replacement fuels as the portion of any motor fuel that is methanol, ethanol, or other alcohols, natural gas, liquefied petroleum gas, hydrogen, coal-derived liquid fuels, fuels (other than alcohol) derived from biological materials, electricity (including electricity from solar energy), ethers, or any other fuel the Secretary of Energy determines, by rule, is substantially not petroleum and would yield substantial energy security benefits and substantial environmental benefits.

${ }^{4}$ Data for biodiesel are not included in this report. However, a discussion is presented in Chapter 3.

5 Energy Information Administration, Alternatives to Traditional Transportation Fuels: An Overview, DOE/EIA-0585(0) (Washington, DC, June 1994). 
some early estimates of AFV inventories and ATF consumption. Subsequently, EIA has published a data report updating AFV and ATF information annually. ${ }^{678}$

EIA derives its information from a wide variety of sources. EIA conducts a survey to determine the number and type of AFV's made available in the current year and expected to be made available in the following year. Industry information and government data are used to estimate the AFV population and ATF consumption. Finally, the U.S. Department of Energy, Office of Energy Efficiency and Renewable Energy, provides EIA with information, both to develop estimates and to report on AFV and ATF progress in the Federal sector.

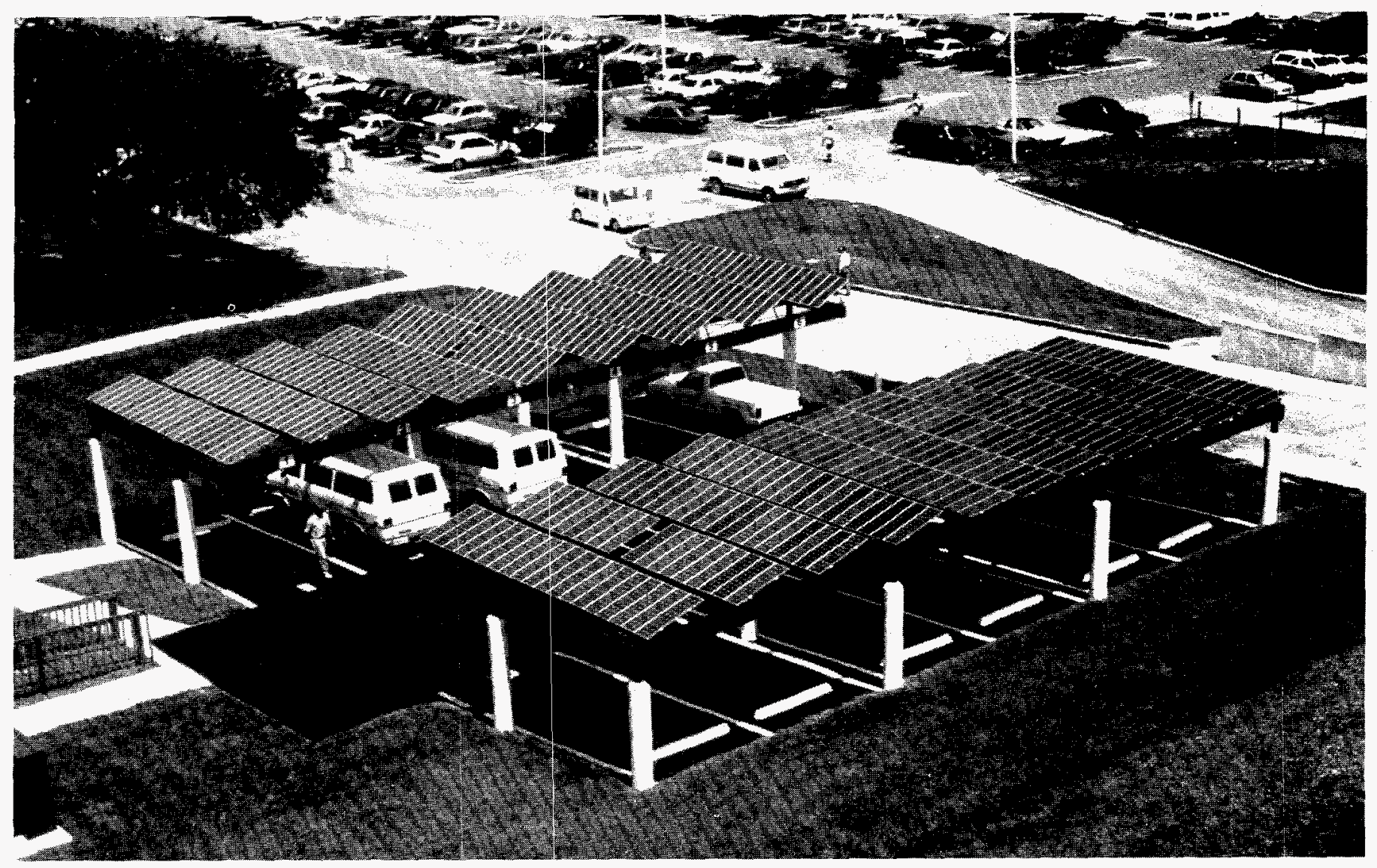

Hybrid vehicles now under development may recharge their batteries at PV power stations such as this one at the University of South Florida. This electric-vehicle recharging station in South Florida is powered by a grid-conected $P V$ array mounted on the roof. When no vehicles need recharging, power from the modules is transferred to the utility line. This is the first PV-powered recharging station in the country. 1995).

Energy Information Administration, Alternatives to Traditional Transportation Fuels 1993, DOE/EIA-0585(93) (Washington, DC, January

7 Energy Information Administration, Alternatives to Traditional Transportation Fuels 1994, Volume 1, DOE/EIA-0585/1(94) (Washington, DC, February 1996). 1996).

Energy Information Administration, Alternatives to Traditional Transportation Fuels 1995, DOE/EIA-0585(95) (Washington, DC, December

9 Energy Information Administration, Form EIA-886, "Alternative Fuel Vehicle Suppliers' Annual Report." 


\section{Alternative-Fueled Vehicles In Use}

The number of alternative-fueled vehicles (AFV's) in use in the United States is expected to reach nearly 403,000 by the end of 1998 (Table 1). The total includes AFV's produced by original equipment manufacturers (OEM's) as well as AFV's made by converting vehicles that were originally designed to operate on gasoline or diesel fuel. The number of AFV's in use is growing at a slightly slower pace than in earlier years. It is expected to increase at an average annual rate of 6.9 percent from 1996 to 1998 , compared to 8.8 percent from 1992 to 1996.

The number of AFV's in use at the end of 1996 is a little lower than estimated a year ago. The lower number reflects slower than expected growth for some types of vehicles, but also results from the use of some newly available data sources which are believed to provide better estimates. Except for compressed natural gas (CNG) vehicles, there have been no significant changes in the methods used to estimate the number of AFV's in use.

In this report, the number of CNG vehicles in use is derived from the EIA-886 survey (see Chapter 4 ). In previous years, CNG vehicle estimates were based on independent surveys of natural gas utilities. For more information on estimating methods and data quality, see Appendix A.

\section{Trends in Alternative-Fueled Vehicles, by Fuel Type}

From 1996 to 1998, ethanol vehicles are expected to increase an average of 51 percent per year, faster than vehicles designed for any other type of alternative fuel. Methanol and liquefied petroleum gas (LPG) vehicles, increasing at average rates of about 3 percent per year, will grow more slowly than other AFV's.

LPG vehicles continue to account for the largest number, although they have declined to 75 percent of all AFV's in 1996, from 88 percent in 1992. By 1998, LPG vehicles are expected to comprise just 69 percent of the AFV's in use in the United States. Meanwhile, the share of vehicles designed to operate on CNG is expected to grow from 9 percent of all AFV's in 1992 to 21 percent in 1998. In

Table 1. Estimated Number of Alternative-Fueled Vehicles in Use in the United States, by Fuel, 1992-1998

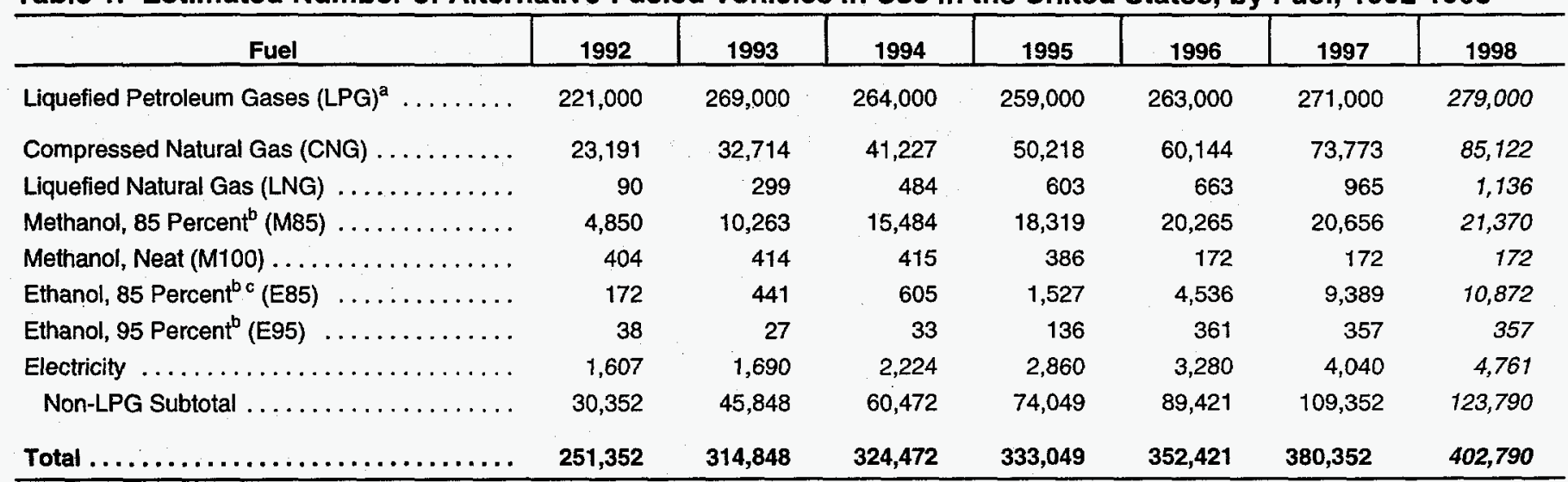

${ }^{2}$ Values are rounded to thousands. Accordingly, these estimates are not equal to the sum of Federal fleet data (for which exact counts are available) and non-Federal fleet estimates (rounded to thousands).

${ }^{b}$ The remaining portion of 85-percent methanol and both ethanol fuels is gasoline.

'Does not include recently announced plans of some major automakers to make available large numbers of vehicles capable of operating on E85 fuel in the near future.

Notes: Estimates for 1996 have been revised. Estimates for 1997, which were based on company plans or projections, have been revised. Estimates for 1998, in italics, are based on plans or projections and may be revised.

Sources: 1992-1995: Science Applications International Corporation, "Alternative Transportation Fuels and Vehicles Data Development," unpublished final report prepared for the Energy Information Administration (McLean, VA, July 1996) and U.S. Department of Energy, Office of Energy Efficiency and Renewable Energy. 1996-1998: Energy Information Administration, Office of Coal, Nuclear, Electric, and Alternate Fuels and U.S. Department of Energy, Office of Energy Efficiency and Renewable Energy. 
absolute number, CNG vehicles will increase more than AFV's of any other fuel type. By 1998, methanol vehicles are expected to make up 5 percent of all AFV's, an increase from 2 percent in 1992. However, most of the growth in methanol vehicles had occurred by 1996 . Rapid increases in the number of E85 (a mixture of 85 percent ethanol and 15 percent gasoline) vehicles have raised the share of ethanol vehicles from less than 0.1 percent in 1992 to 2.8 percent of all AFV's in 1998. From 1996 to 1998, the number of electric vehicles is expected to increase at about the same rate as in earlier years; by 1998, electric vehicles will make up just over 1 percent of AFV's.

Each year, more and more AFV's are being provided by OEM's. In 1997, several types of AFV's, including both light- and heavy-duty vehicles of various fuel types, are available from OEM's. During the year, several of the OEM's made announcements about new offerings of AFV's that they expect to make available in the near future. Both Ford Motor Company and Chrysler Corporation announced that they intend to produce large numbers of flexible-fuel vehicles (mostly minivans and pickup trucks) that are capable of operating on E85 and/or gasoline. These AFV's have not been included in EIA estimates, due to uncertainties about timing and about their distributions by region and ownership, but estimates from both manufacturers indicate that these vehicles alone could more than double the number of AFV's in use in the next 4 or 5 years. It should be noted, however, that most of these vehicles are expected to operate on gasoline, rather than E85. ${ }^{10}$

Another factor which may affect AFV trends, by fuel type, is zero-emission vehicles (ZEV) mandates in some States, which would essentially require sales of electric vehicles. Although California has delayed its ZEV mandates until 2003, a recent court ruling upheld New York's right to implement ZEV requirements beginning this year. The New York mandate would require that 2 percent of the vehicles sold in the State, beginning in model year 1998, be ZEV's. Auto manufacturers have appealed the ruling, arguing that, among other things, there will not be enough demand for the electric vehicles they are required to sell, but a ruling on the appeal is not expected before February of $1998 .^{11}$

Also, in 1997, the Federal tax rates on propane, methanol, and liquefied natural gas (LNG) used as a vehicle fuel were lowered. The new taxes were scheduled to take effect in October 1997. Particularly for LNG and LPG vehicles, this could suggest growing numbers of AFV's in the near future.

\section{Regional Distribution of AFV's}

As in previous years, the largest numbers of AFV's are located in the South, followed by the West, the Midwest, and the Northeast (Table 2). (Census regions are defined in Appendix B.) However, between 1996 and 1998, the most rapid growth in the number of AFV's is expected to occur in the Midwest, where growth in ethanol and natural gas vehicles is expected to be strong. In that region, $A F V$ 's are expected to increase by 16 percent from 1996 to 1998, compared to nationwide growth of 14 percent. The South is expected to experience the slowest growth, 13 percent.

The States with the largest numbers of AFV's are California, Texas, Illinois, Oklahoma, and Ohio (Table 3). In 1996, 42 percent of the AFV's in the United States were located in those five States. Five additional States are estimated to have more than 10,000 AFV's in use in 1996: Michigan, Pennsylvania, New York, Florida, and Georgia. The estimated numbers of AFV's in some States have been revised since last year's report due to new source data or the new CNG methodology. The numbers of AFV's in Arizona, Indiana, Kansas, Kentucky, Mississippi, New Mexico, New York, North Carolina, South Dakota, Virginia, and Wisconsin are somewhat lower than was estimated last year. On the other hand, estimates of AFV's in Oklahoma have been revised upward significantly due to new source information.

Estimates of AFV's in use, by fuel type, for each of the 50 States are presented in the 1996 report for the first time (Table 4). These estimates should not be viewed as enumerations of the different types of AFV's in each State, but rather as "best estimates". For the largest fuel types, LPG and CNG, national totals were distributed to the States according to distributions of related sources. For others, the national total was aggregated from the best estimates for each State.

Other indicators of regional AFV development are the designation of new Clean Cities and the addition of alternative-fueled refueling sites. As of September 1997, five metropolitan areas were designated as Clean Cites,

\footnotetext{
${ }^{10}$ For more information about OEM offerings, see the "Resource Guides" that are available from the Alternative Fuels Data Center (Web site: www.afdc.doe.gov).

${ }^{11}$ Automotive News (Detroit, MI, September 29, 1997), p. 8.
} 
Table 3. Estimated Number of Alternative-Fueled Vehicles In Use, by State, 1996-1998

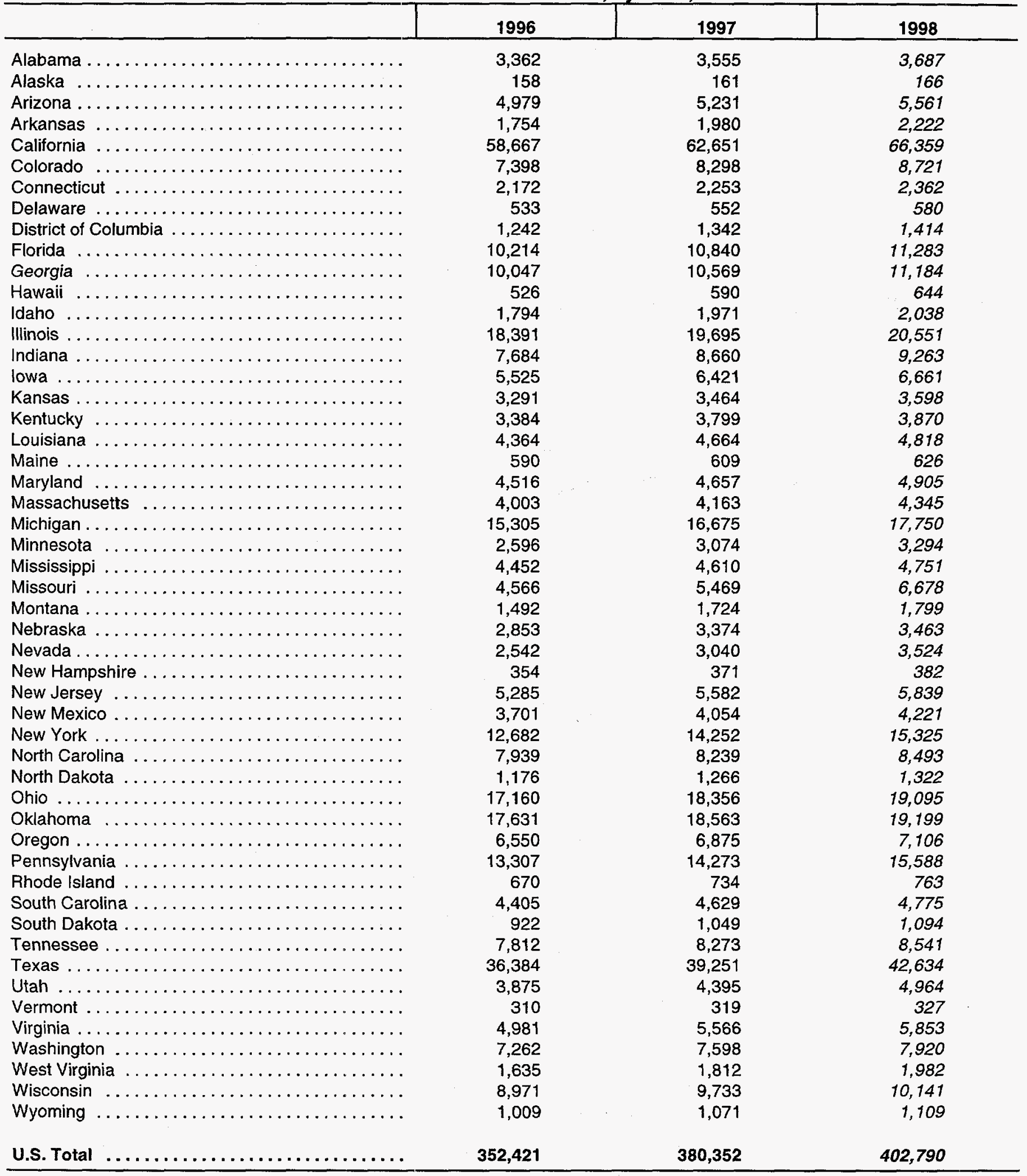

Note: Estimates for 1996 and 1997 have been revised. Estimates for 1997 are preliminary and those for 1998 , in italics, are based on plans or projections. Estimates for historical years may be revised in future reports if new information becomes available.

Source: Energy Information Administration, Office of Coal, Nuclear, Electric, and Alternate Fuels. 
Table 4. Estimated Number of Alternative-Fueled Vehicles In Use, by State and Fuel Type, 1996

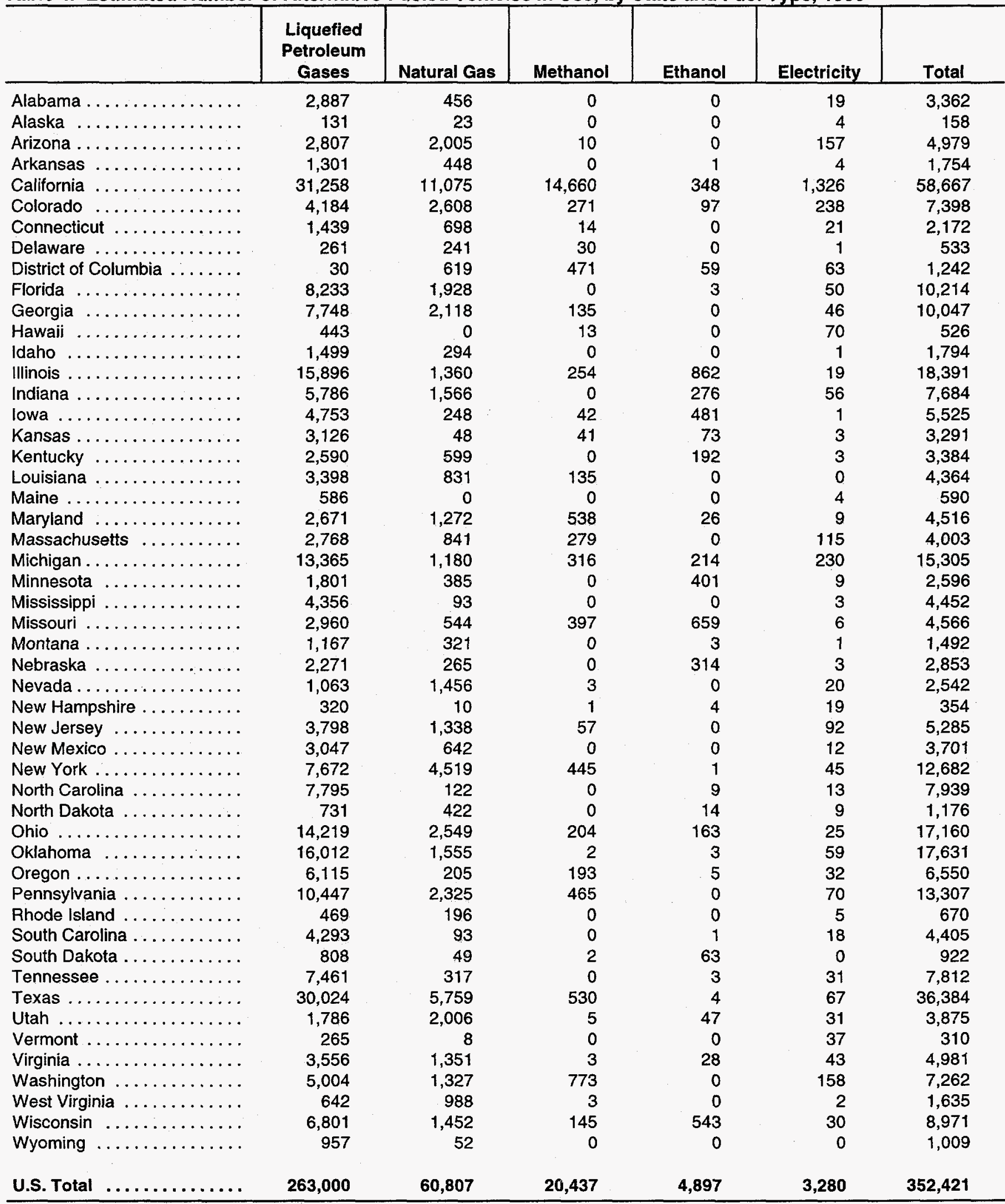

Notes: Natural gas includes compressed natural gas (CNG) and liquefied natural gas (LNG). Methanol includes M85 and M100. Ethanol includes E85 and E95. Data for 1996 has been revised.

Source: Energy Information Administration, Office of Coal, Nuclear, Electric, and Alternative Fuels. 
raising the total number of Clean Cities to $57 .{ }^{12}$ Of those added in 1997, two were in the Midwest, two in the South, and one in the Northeast. Four cities in California, two in Texas, and one each in Louisiana, Florida, and New York were "nearing designation" in September 1997. The growth of an AFV infrastructure, as measured by the number of available alternative-fueled refueling sites, continues. Of the currently known sites, about 40 percent are located in the South, about 25 percent in each of the Midwest and West, and 10 percent in the Northeast (Table 5).

\section{Alternative-Fueled Vehicles; by Vehicle Type}

From 1996 to 1998, the number of heavy-duty AFV's in use is expected to increase just slightly faster than lightduty AFV's (an average rate of 7.4 percent compared to 6.8 percent for light-duty AFV's) (Table 6). In total, lightduty AFV's will remain at about 82 percent of all AFV's during the period. For certain fuel types, however, somewhat significant shifts away from light-duty AFV's appear to be occurring. In 1992, just 10 percent of CNG vehicles and 1 percent of electric vehicles in-use were heavy-duty vehicles. ${ }^{13}$ By 1998, 19 percent of onroad CNG vehicles and 4 percent of onroad electric vehicles are expected to be heavy-duty vehicles. EIA- 886 data indicate these trends are likely to continue. Twenty-six percent of the onroad CNG vehicles and 27 percent of the onroad electric vehicles made available in 1996 were heavy-duty vehicles. Shifts toward heavier duty vehicles can have a significant impact on alternative fuel usage because those vehicles tend to consume much higher quantities of fuel.

Transit buses are one type of heavy-duty vehicle that have seen much AFV activity. In 1996, one out of every five new transit buses on order was an alternative-fuelcapable bus. ${ }^{14}$ Using newly available data from the American Public Transit Association (APTA) and the Federal Transit Administration (FTA), the Energy Information Administration has identified 2,628 alternativefueled transit buses in use in 1996. That number is expected to increase to 4,421 in 1998 . Just over threefourths of the alternative-fueled transit buses in use in
1996 were designed to operate on natural gas. Transit buses also operated on methanol, ethanol, propane, and electricity. Alternative-fueled transit buses operated in 38 States. Forty percent were located in California and another 42 percent were located in the States of Texas, New York, Georgia, Ohio and Washington combined. On average, alternative-fuel transit buses traveled over 30,000 miles annually, similar to their non-AFV counterparts. Only electric transit buses operated significantly fewer miles per year, averaging between 7 and 8 thousand miles per year.

\section{Alternative-Fueled Vehicles by Ownership}

The majority of LPG vehicles in use (about 80 percent) are privately owned. ${ }^{15}$ By contrast, only about 45 percent of the non-LPG AFV's were privately owned in 1996 (Table 7). The remaining publicly-owned AFV's were split fairly evenly between State and local ( 28 percent) and Federal (26 percent) governments. The picture is expected to change a little by 1998 , when it is estimated that 50 percent of the non-LPG AFV's in use may be privately owned, 31 percent State and locally owned (Table 8), and 19 percent Federally owned (Table 9). Two factors are probably most responsible for the shift. First, Federal government AFV's are being resold to the private and State and local sectors. Second, mandates requiring State and fuel provider fleets to acquire AFV's took effect in model year 1997.

AFV mandates for local (municipal) and private fleets other than fuel providers' fleets are currently pending. According to the Energy Policy Act of 1992 (EPACT), municipal and private fleet operators will have to acquire increasing percentages of $A F V$ 's, similar to State and fuel provider fleets, if the Secretary of Energy determines it is necessary in order to meet the motor fuel replacement goals of the law. In order for those mandates to begin in model year 1999 (the "early" schedule proposed by EPACT), a rulemaking had to be completed by December 1996. A rulemaking was not promulgated in 1996. Analytical work to determine the necessity of the mandates using a later schedule is currently underway, and the

\footnotetext{
${ }^{12}$ The clean Cities program is a voluntary program sporssored by the U.S. Department of Energy (DOE) to promote the use of AFV's. Cities achieve clean cities designation after developing a memorandum of understanding between AFV stakeholders and the DOE. For more information, see the Clean Cities web site - www.ccities.cloe.gov.

${ }^{13}$ Energy Information Administration, Alternatives To Traditional Transportation Fuels 1994, Volume 1, DOE/EIA-0585/1(94) (Washington, DC, February 1996).

${ }^{14}$ National Renewable Energy Laboratory, Alternative Fuel Transit Buses, Final Results from the National Renewable Energy Laboratory Vehicle Evaluation Program (Golden, CO, October 1996).

${ }^{15}$ The owrership classifications of LPG vehicles estimated to be in use prior to 1995 have been changed. More recent estimates for 1995 to 1997 indicate that a lower percentage of LPG vehicles are privately owned, and a higher percentage owned by State and local governments, than was reported when these numbers were published two years ago. The differing percentages are believed to result from improved data sources that better identify ownership, rather than from any switching of vehicles between categories, so these revisions were carried back to earlier years.
} 


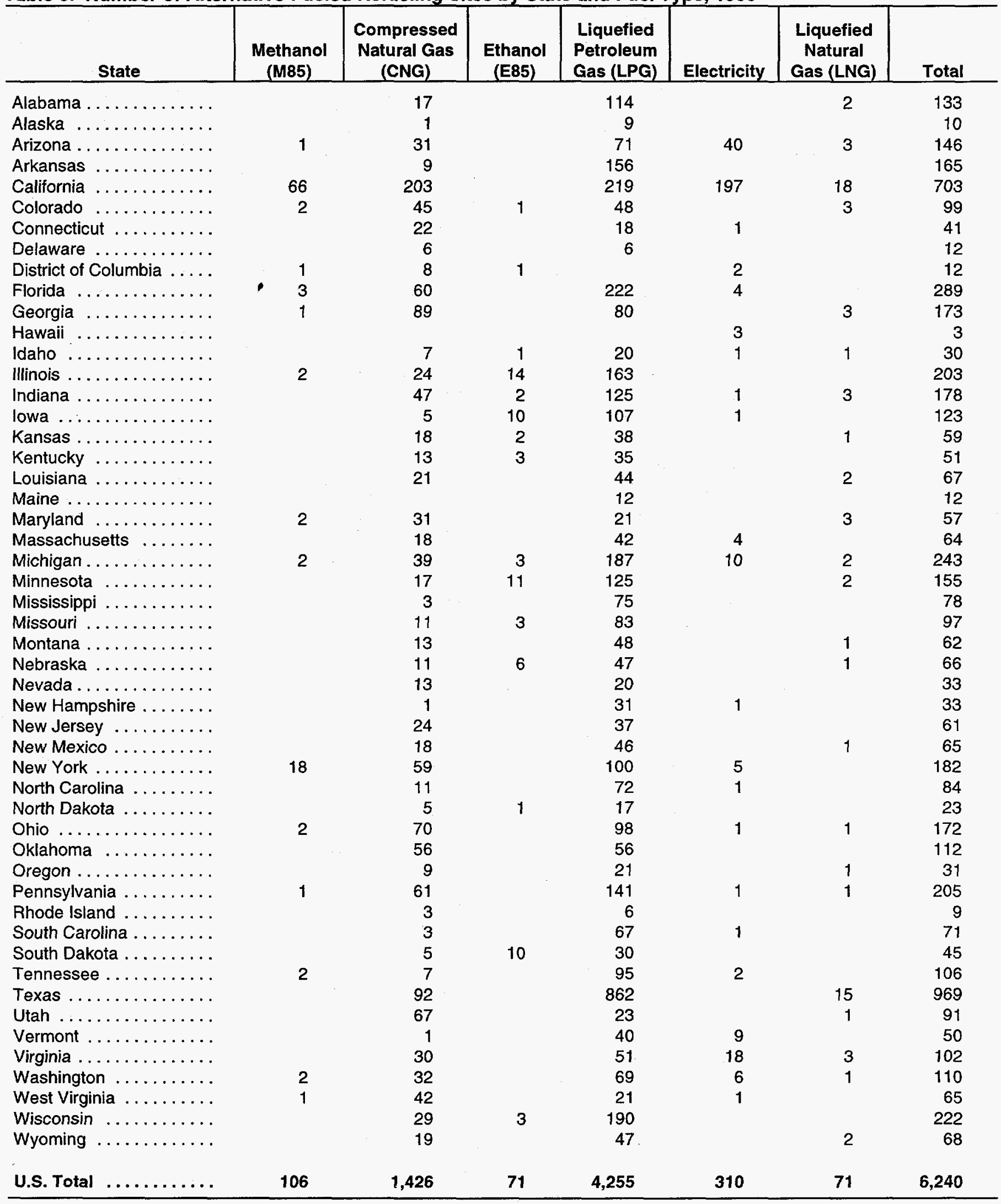

Source: U.S. Department of Energy, National Renewable Energy Laboratory, Alternative Fuels Data Center Database (Extracted October 6, 1997). 
Table 6. Estimated Number of Alternative-Fueled Vehicles in Use in the United States, by Fuel and Weight Category, 1994, 1996, and 1998

\begin{tabular}{|c|c|c|c|c|c|c|c|c|c|}
\hline \multirow[b]{2}{*}{ Fuel } & \multicolumn{3}{|c|}{1994} & \multicolumn{3}{|c|}{1996} & \multicolumn{3}{|c|}{1998} \\
\hline & $\begin{array}{l}\text { Light } \\
\text { Duty }\end{array}$ & $\begin{array}{c}\text { Heavy } \\
\text { Duty }\end{array}$ & Total & $\begin{array}{l}\text { Light } \\
\text { Duty }\end{array}$ & $\begin{array}{c}\text { Heavy } \\
\text { Duty }\end{array}$ & Total & $\begin{array}{l}\text { Light } \\
\text { Duty }\end{array}$ & $\begin{array}{c}\text { Heavy } \\
\text { Duty }\end{array}$ & Total \\
\hline Liquefied Petroleum Gases (LPG) ${ }^{a}$ & 212,000 & 52,000 & 264,000 & 210,000 & 53,000 & 263,000 & 223,000 & 56,000 & 279,000 \\
\hline Compressed Natural Gas (CNG). & 35,970 & 5,257 & 41,227 & 50,270 & 9,874 & 60,144 & 68,734 & 16,388 & 85,122 \\
\hline Liquefied Natural Gas (LNG) & 94 & 390 & 484 & 127 & 536 & 663 & 267 & 869 & 1,136 \\
\hline Methanol, 85 Percent $^{b}$ (M85) & 15,376 & 108 & 15,484 & 20,259 & 6 & 20,265 & 21,364 & 6 & 21,370 \\
\hline Methanol, Neat $(\mathrm{M} 100) \ldots \ldots$. & 0 & 415 & 415 & 0 & 172 & 172 & 0 & 172 & 172 \\
\hline Ethanol, 85 Percent $^{\mathrm{b}}$ (E85) & 605 & 0 & 605 & 4,536 & 0 & 4,536 & 10,872 & 0 & 10,872 \\
\hline Ethanol, 95 Percent $^{b}$ (E95) & 2 & 31 & 33 & 0 & 361 & 361 & 0 & 357 & 357 \\
\hline Electricity $\ldots \ldots \ldots \ldots$ & 2,163 & 61 & 2,224 & 3,126 & 154 & 3,280 & 4,562 & 199 & 4,761 \\
\hline Non-LPG Subtotal $\ldots \ldots \ldots \ldots \ldots$ & 54,210 & 6,262 & 60,472 & 78,318 & 11,103 & 89,421 & 105,799 & 17,991 & 123,790 \\
\hline Total . ............ & 266,210 & 58,262 & 324,472 & 288,318 & 64,103 & 352,421 & 328,799 & 73,991 & 402,790 \\
\hline
\end{tabular}

avalues are rounded to thousands.

${ }^{b}$ The remaining portion of 85 -percent methanol and both ethanol fuels is gasoline.

Note: Weight classes are based on Environmental Protection. Agency definitions: light duty is less than or equal to 8500 pounds gross vehicle weight; heavy duty is greater than 8,500 pounds gross vehicle weight. Estimates for historical years may be revised in future reports if new information becomes available. Estimates for 1998, in italics, are based on plans or projections. Data for 1994 and 1996 have been revised.

Sources: 1994: Science Applications Intemational Corporation, "Alternative Transportation Fuels and Vehicles Data Development," unpublished final report prepared for the Energy Information Administration (McLean, VA, August 1995) and Energy Information Administration, Office of Coal, Nuclear, Electric, and Alternate Fuels. 1996 and 1998: Energy Information Administration, Office of Coal, Nuclear, Electric, and Alternate Fuels.

Table 7. Estimated Number of Alternative-Fueled Vehicles in Use by U.S. Private Entities, by Fuel and Weight Category, 1994, 1996, and 1998

\begin{tabular}{|c|c|c|c|c|c|c|c|c|c|}
\hline \multirow[b]{2}{*}{ Fuel } & \multicolumn{3}{|c|}{1994} & \multicolumn{3}{|c|}{1996} & \multicolumn{3}{|c|}{1998} \\
\hline & Light Duty & $\begin{array}{c}\text { Heavy } \\
\text { Duty }\end{array}$ & Total & $\begin{array}{l}\text { Light } \\
\text { Duty }\end{array}$ & $\begin{array}{c}\text { Heavy } \\
\text { Duty }\end{array}$ & Total & Light Duty & $\begin{array}{c}\text { Heavy } \\
\text { Duty }\end{array}$ & Total \\
\hline Liquefied Petroleum Gases (LPG) ${ }^{a}$ & 169,000 & 42,000 & 211,000 & 167,000 & 43,000 & 210,000 & 178,000 & 45,000 & 223,000 \\
\hline Compressed Natural Gas (CNG) & 21,496 & 2,935 & 24,431 & 25,020 & 5,485 & 30,505 & 37,755 & 9,104 & 46,859 \\
\hline Liquefied Natural Gas (LNG) & 27 & 12 & 39 & 10 & 77 & 87 & 12 & 136 & 148 \\
\hline Methanol, 85 Percent $^{\mathrm{b}}$ (M85) & 3,675 & 0 & 3,675 & 6,633 & 0 & 6,633 & 9,302 & 0 & 9,302 \\
\hline Methanol, Neat $(M 100) \ldots \ldots$ & 0 & 1 & 1 & 0 & 0 & 0 & 0 & 0 & 0 \\
\hline Ethanol, 85 Percent $^{D}$ (E85) & 58 & 0 & 58 & 793 & 0 & 793 & 1,906 & 0 & 1,906 \\
\hline Ethanol, 95 Percent $^{b}$ (E95) & 1 & 5 & 6 & 0 & 4 & 4 & 0 & 0 & 0 \\
\hline Electricity ........ & 2,047 & 8 & 2,055 & 2,451 & 32 & 2,483 & 3,398 & 42 & 3,440 \\
\hline Non-LPG Subtotal & 27,304 & 2,961 & 30,265 & 34,907 & 5,598 & 40,505 & 52,373 & 9,282 & 61,655 \\
\hline Total ..... & 196,304 & 44,961 & 241,265 & 201,907 & 48,598 & 250,505 & 230,373 & 54,282 & 284,655 \\
\hline
\end{tabular}

${ }^{a}$ Values are rounded to thousands.

'The remaining portion of 85-percent methanol and both ethanol fuels is gasoline.

Note: Weight classes are based on Environmental Protection Agency definitions: light duty is less than or equal to 8500 pounds gross vehicle weight; heavy duty is greater than 8,500 pounds gross vehicle weight. Estimates for historical years may be revised in future reports if new information becomes available. Estimates for 1996 have been revised. Estimates for 1998, in italics, are based on plans or projections.

Sources: 1994: Science Applications International Corporation, "Alternative Transportation Fuels and Vehicles Data Development," unpublished final report prepared for the Energy Information Administration (McLean, VA, August 1995) and Energy Information Administration, Office of Coal, Nuclear, Electric, and Alternate Fuels. 1996 and 1998: Energy Information Administration, Office of Coal, Nuclear, Electric, and Alternate Fuels. 
Table 8. Estimated Number of Alternative-Fueled Vehicles in Use by State and Local Governments, by Fuel and Weight Category, 1994, 1996, and 1998

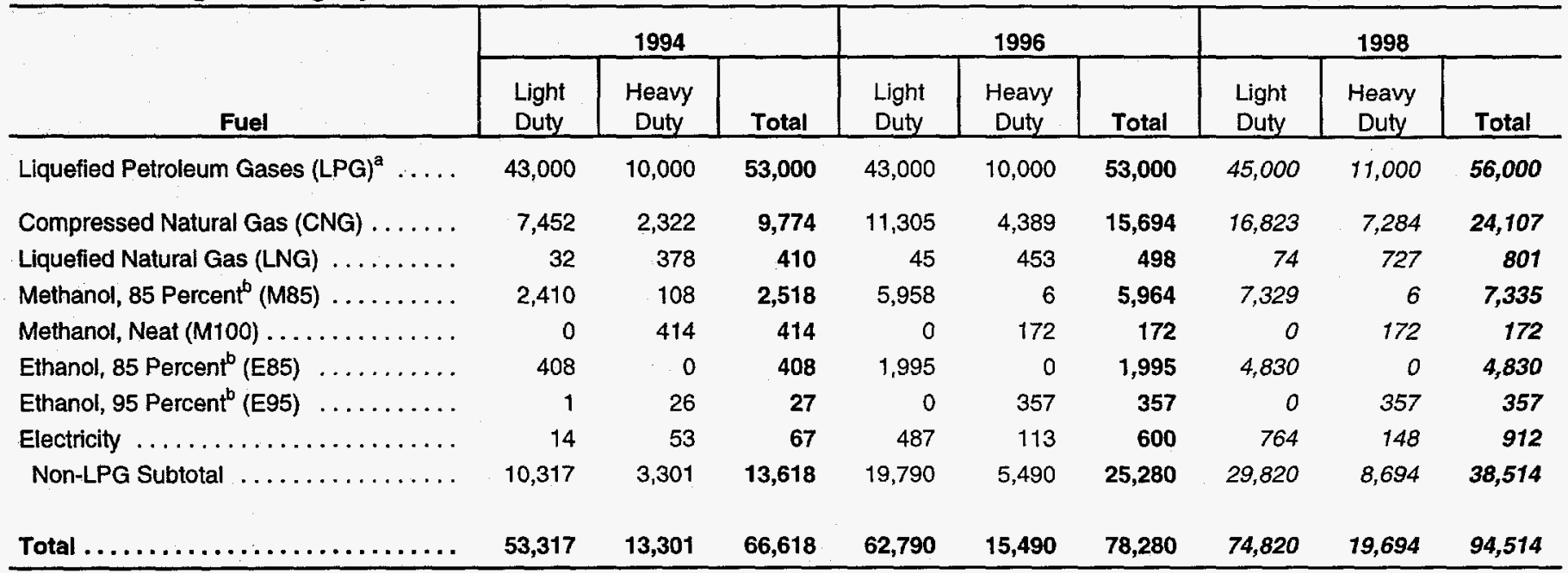

avalues are rounded to thousands.

'The remaining portion of 85-percent methanol and both ethanol fuels is gasoline.

Note: Weight classes are based on Environmental Protection Agency definitions: light duty is less than or equal to 8500 pounds gross vehicle weight; heavy duty is greater than 8,500 pounds gross vehicle weight. Estimates for historical years may be revised in future reports if new information becomes available. Estimates for 1996 have been revised. Estimates for 1998, in italics, are based on plans or projections.

Sources: 1994: Science Applications International Corporation, "Alternative Transportation Fuels and Vehicles Data Development," unpublished final report prepared for the Energy Information Administration (McLean, VA, August 1995) and Energy Information Administration, Office of Coal, Nuclear, Electric, and Alternate Fuels. 1996 and 1998: Energy Information Administration, Office of Coal, Nuclear, Electric, and Alternate Fuels.

Department of Energy (DOE) is scheduled to publish an advanced notice of proposed rulemaking on April 1, 1998.

The responsibilities of Federal agencies with regard to AFV's were clarified in December 1996 when the President signed Executive Order 13031. The order states that "each Federal agency shall develop and implement aggressive plans to fulfill the alternative-fueled vehicle acquisition requirements" of EPACT. In general, EPACT requires that in fiscal years 1996, 1997, 1998, 1999 and thereafter, 25, 33, 50, and 75 percent, respectively, of the covered light-duty vehicles acquired by the Federal government must be AFV's. The Executive Order also states that each Federal agency must file an annual report detailing its compliance with the requirements, that agencies may receive extra credits for acquiring dedicated electric, medium-duty and heavy-duty AFV's, and that agencies should use alternative fuels in their AFV's to the extent practicable. The estimates in Table 9 are based on the results of this new reporting system. Adjustments have been made to account for retirements of AFV's and AFV credits. The credits were converted to represent actual vehicle numbers for this report.
Even though the Federal Government acquired about 6,000 AFV's in fiscal year 1996, which amounted to 23 percent of its covered light-duty vehicle acquisitions (2 percent short of the EPACT requirement), ${ }^{16}$ the number of Federal AFV's in use has not grown significantly because the Federal government has begun to retire AFV's. The Federal government usually retires sedans from its fleet 3 years after their acquisition, and light-duty trucks and vans after 6 years. Retirements, particularly of earlier methanol and CNG vehicles are reflected in this year's report. More retirements are expected in 1997 and 1998, so despite expected increases in acquisitions, the number of AFV's in the Federal fleet is expected to remain fairly stable. Most of the retired Federal AFV's, however, were resold to the private or State and local sectors, so that the national population of AFV's did not diminish with retirements of Federal AFV's.

In 1992, CNG and methanol vehicles made up 99 percent of the Federal AFV fleet. ${ }^{17}$ In 1998, vehicles designed for these two fuels are expected to account for 79 percent of the fleet, with ethanol and electric vehicles accounting for most of the remainder. Chrysler Corporation recently

\footnotetext{
${ }^{16}$ U.S. Department of Energy, Office of Energy Efficiency and Renewable Energy.

${ }^{17}$ Energy Information Administration, Alternatives To Traditional Transportation Fuels 1994, Volume 1, DOE/EIA-0585/1(94) (Washington, DC, February 1996).
} 
Table 9. Estimated Number of Alternative-Fueled Vehicles in Use by the U.S. Federal Government, by Fuel and Weight Category, 1994, 1996, and 1998

\begin{tabular}{|c|c|c|c|c|c|c|c|c|c|}
\hline \multirow[b]{2}{*}{ Fuel } & \multicolumn{3}{|c|}{1994} & \multicolumn{3}{|c|}{1996} & \multicolumn{3}{|c|}{1998} \\
\hline & $\begin{array}{l}\text { Light } \\
\text { Duty }\end{array}$ & $\begin{array}{l}\text { Heavy } \\
\text { Duty }\end{array}$ & Total & $\begin{array}{l}\text { Light } \\
\text { Duty }\end{array}$ & $\begin{array}{c}\text { Heavy } \\
\text { Duty }\end{array}$ & Total & $\begin{array}{l}\text { Light } \\
\text { Duty }\end{array}$ & $\begin{array}{c}\text { Heavy } \\
\text { Duty }\end{array}$ & Total \\
\hline Liquefied Petroleum Gases (LPG) . . . . & 33 & 2 & 35 & 193 & 2 & 195 & 380 & 2 & 382 \\
\hline Compressed Natural Gas (CNG) . . . . . & 7,022 & 0 & 7,022 & 13,945 & 0 & 13,945 & 14,156 & 0 & 14,156 \\
\hline Liquefied Natural Gas (LNG) . . . . . . . & 35 & 0 & 35 & 72 & 6 & 78 & 181 & 6 & 187 \\
\hline Methanol, Neat $(\mathrm{M} 100) \ldots \ldots \ldots \ldots$ & 0 & 0 & $\mathbf{0}$ & 0 & 0 & 0 & 0 & 0 & 0 \\
\hline Ethanol, 85 Percent $^{b}$ (E85) $\ldots$ & 139 & 0 & 139 & 1,748 & 0 & 1,748 & 4,136 & 0 & 4,136 \\
\hline Ethanol, 95 Percent $^{b}$ (E95) .... . & 0 & 0 & $\mathbf{0}$ & 0 & 0 & 0 & 0 & 0 & 0 \\
\hline Electricity & 102 & 0 & 102 & 188 & 9 & 197 & 400 & 9 & 409 \\
\hline Non-LPG Subtotal $\ldots \ldots \ldots \ldots \ldots$ & 16,589 & 0 & 16,589 & 23,621 & 15 & 23,636 & 23,606 & 15 & 23,621 \\
\hline
\end{tabular}

The remaining portion of 85-percent methanol and both ethanol fuels is gasoline.

Notes: Weight classes are based on Environmental Protection Agency definitions: light duty is less than or equal to 8,500 pounds gross vehicle weight; heavy duty is greater than 8,500 pounds gross vehicle weight. Estimates for historical years may be revised in future reports if new information becomes available. Estimates for 1996 have been revised. Estimates for 1998, in italics, are based on plans or projections.

Source: Energy Information Administration, Office of Coal, Nuclear, Electric, and Alternate Fuels. Derived from Federal vehicle acquisitions data from U.S. Department of Energy, Office of Energy Efficiency and Renewable Energy, supplemented with data from individual Federal agencies.

announced that it would offer flexible-fuel minivans with E85 capability at no additional cost to its Federal fleet customers beginning in Model year 1998. In addition, Executive Order 13031 states that the DOE will no longer provide funding to Federal agencies for the incremental cost of AFV's, except for electric vehicles. For fiscal year
1998, the DOE has received budgeted funds to assist Federal agencies with up to 50 percent of the incremental cost of purchasing electric vehicles. These two factors, along with continued retirements of older AFV's, could substantially change the composition of the Federal AFV fleet in the future. 


\section{Alternative and Replacement Fuel Consumption}

Rapid growth in the blending of oxygenates (alcohols and ethers) with gasoline caused consumption of alternative and replacement fuels to grow much faster than consumption of traditional vehicular fuels during the first half of the 1990's. ${ }^{18}$ Blending of oxygenates increased greatly after the Clean Air Act Amendments of 1990 established requirements for the use of oxygenated and reformulated gasoline in a number of large metropolitan areas. Although oxygenate consumption has leveled off somewhat since the reformulated gasoline mandates took effect in 1995, consumption of alternative and replacement fuels continues to increase faster than consumption of traditional transportation fuels.

From 1992 to 1996, alternative and replacement fuel consumption (measured in gasoline-equivalent gallons) increased 76 percent (15.2 percent annualized rate), while consumption of traditional highway fuels increased just 10 percent. From 1996 to 1998 , consumption of alternative and replacement fuels is expected to increase 9 percent (4.3 percent annualized rate), compared to a 4 percent increase for traditional fuels. As a result of their faster growth rates, alternative and replacement fuels now comprise 2.5 percent of onroad transportation fuel, compared with 1.6 percent in 1992. Their share is expected to reach 2.6 percent in 1998.

Although oxygenates account for more than 90 percent of alternative and replacement fuels and are the main factors in growth trends, they are growing only about half as fast as alternative transportation fuels (ATF's). ${ }^{19}$ From 1996 to 1998, consumption of ATF's is expected to increase 15 percent while oxygenate consumption is expected to increase 8 percent. The ATF's alone accounted for 0.17 percent of onroad fuel consumption in 1992 and 0.20 percent in 1996; ATF's are expected to account for 0.22 percent in 1998.

\section{Alternative Fuels}

Alternative-fueled consumption, by fuel type (Table 10), is estimated from the numbers of AFV's in use (see
Chapter 2). Total ATF consumption is based on underlying estimates of average vehicle miles traveled (VMT), miles per gallon (mpg) of fuel consumed, the mix of dedicated and non-dedicated vehicles, and the percentage of ATF used in non-dedicated vehicles. A more detailed explanation of the estimation methodology is provided in Appendix A.

In this report, estimates of E95 and M85 consumption for 1995 have been revised, even though there is no corresponding revision in the number of AFV's. In the case of E95, performance data from E95 vehicles were found to be different enough from previous VMT and mpg estimates to warrant revision. The new data were obtained from the Federal Transit Administration and from the heavy-duty demonstration program database at the Alternative Fuels Data Center (AFDC). ${ }^{20}$ The new sources indicated higher levels of fuel consumption per vehicle than previously estimated for 1995 and beyond. In the case of M85, 1995 consumption was revised downward and lower levels carried forward through 1998. This revision applies to Federal consumption only, which was recalculated using lower VMT estimates that are more appropriate than those used in Alternatives to Traditional Transportation Fuels 1995 for Federal government vehicles.

Other differences between consumption estimates reported last year and those shown in this report are mostly due to changing AFV estimates. Consumption of E85 in 1996 and 1997 is higher than reported last year because of the higher estimated number of E85 vehicles in use. Estimated CNG consumption is lower for those years because of reduced vehicle estimates. In some cases, new information obtained this year was used to refine the estimates of VMT, mpg, the mix of dedicated and nondedicated vehicles, or the percentage use of ATF's in nondedicated vehicles. The new data applied mostly to transit buses, and to CNG and LPG vehicles. The new source data did cause some small revisions.

In general, alternative-fueled consumption increases at about the same rate as the number of AFV's. Over time, however, changes in the composition of the vehicle stock

\footnotetext{
${ }^{18}$ In this report, the term "alternative and replacement fuels" refers to all alternative fuels, as defined in Section 301 of the Energy Policy Act of 1992 (EPACT), plus oxygenates or other qualified fuels that are blended with traditional fuels in smaller amounts than is required to meet the criteria for an alternative fuel. Traditional vehicular fuels are gasoline and diesel fuel.

${ }^{19}$ Alternative transportation fuels are defined by Section 301 of EPACT. See Chapter 1 for the EPACT definition.

${ }^{20}$ Federal Transit Administration, “1995 National Transit Database, June 1997." The AFDC database can be accessed at www.afdc.doe.gov.
} 
Table 10. Estimated Consumption of Vehicle Fuels in the United States, 1992-1998 (Thousand Gasoline-Equivalent Gallons)

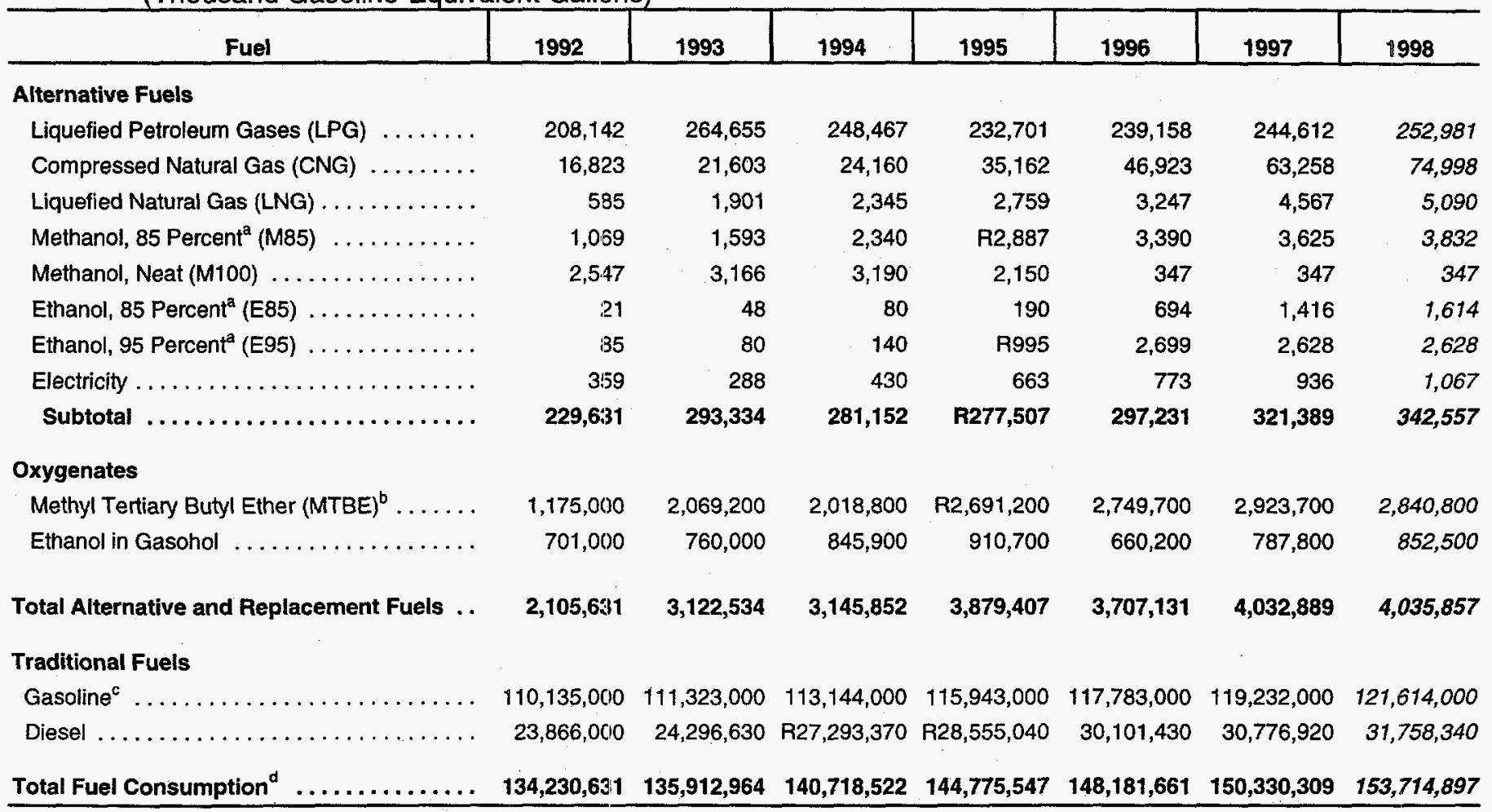

${ }^{2}$ The remaining portion of 85-percent methanol and both ethanol fuels is gasoline. Consumption data include the gasoline portion of the fuel.

bIncludes a very small amount of other ethers, primarily Tertiary Amyl Methyl Ether (TAME) and Ethyl Tertiary Butyl Ether (ETBE).

${ }^{c}$ Gasoline consumption includes ethanol in gasohol and MTBE.

${ }^{\circ}$ Total fuel consumption is the sum of altemative fuel, gasoline, and diesel consumption. Oxygenate consumption is included in gasoline consumption.

$R=$ Revised

Notes: Fuel quantities are expressed in a common base unit of gasoline-equivalent gallons to allow comparisons of different fuel types. Gasolineequivalent gallons do not represent gasoline displacement. Gasoline equivalent is computed by dividing the lower heating value of the alternative fuel by the lower heating value of gasoline and multiplying this result by the alternative fuel consumption value. Lower heating value refers to the Btu content per unit of fuel excluding the heat produced by condensation of water vapor in the fuel. Totals may not equal sum of components due to independent rounding. Estimates for 1994-1997 have been revised. Estimates for 1997 are preliminary and those for 1998, in italics, are based on plans or projections. Estimates for historical years may be revised in future reports if new information becomes available.

Sources: 1992-1996 Oxygenate Consumption: Energy Information Administration, Petroleum Supply Monthly. 1992-1996 Traditional Fuel Consumption: Energy Information Administration, Petroleum Supply Annual, Volume 1 (June 1997). Highway use of gasoline was estimated as 97.1 percent of consumption, based on data in the Transportation Energy Data Book: Edition 16, prepared by Oak Ridge National Laboratory for the U.S. Department of Energy (July 1996). Diesel consumption was adjusted for highway use by multiplying by .521 derived from Energy Information Administration, Fuel Oil and Kerosene Sales 1994. 1997-1998 Oxygenate and Traditional Fuel Consumption: Energy Information Administration, Short Term Energy Outlook, September 1997. 1992-1995 Alternative Fuel Consumption: Science Applications International Corporation, "Alternative Transportation Fuels and Vehicles Data Development," unpublished final report prepared for the Energy Information Administration (McLean, VA, July 1996). 1996-1998 Alternative Fuel Consumption: Energy information Administration, Office of Coal, Nuclear, Electric and Alternate Fuels.

or in the proportions of ATF used in non-dedicated AFV's could cause the growth rates to differ. Increasing percentages of heavy-duty or dedicated AFV's in the total stock would most likely cause ATF consumption to increase faster than AFV's. On the other hand, factors such as higher ATF prices, decreased ATF availability, or poor vehicle performance, that would persuade drivers of nondedicated vehicles to use less ATF, would likely cause consumption to increase more slowly than the number of AFV's.

From 1996 to 1998 , ATF consumption is expected to grow slightly faster than the number of AFV's, 15 percent compared to 14 percent. The difference is mostly attributable to CNG. CNG consumption is expected to increase 60 percent during the period while $C N G$ vehicles increase 42 percent. The shift toward heavy-duty $\mathrm{CNG}$ vehicles (which are expected to increase from 16 percent to 19 percent of CNG vehicles) appears to account for the discrepancy in growth rates. In particular, a large increase in CNG transit buses, which have the highest VMT of all CNG vehicles, accounts for much of the difference.

The regional distribution of ATF consumption closely follows the distribution of AFV's. Consumption is lowest in the Northeast, which accounted for 11 percent of ATF consumption in 1996, and highest in the South, which accounted for 37 percent (Table 11). Differences in the 
Table 11. Estimated Share of Alternative Transportation Fuel Consumption, by Region, 1996-1998 (Percent)

\begin{tabular}{|c|c|c|c|c|c|c|c|c|c|c|c|c|}
\hline \multirow[b]{2}{*}{ Fuel } & \multicolumn{4}{|c|}{1996} & \multicolumn{4}{|c|}{1997} & \multicolumn{4}{|c|}{1998} \\
\hline & $\begin{array}{c}\text { North- } \\
\text { east }\end{array}$ & South & $\begin{array}{l}\text { Mid- } \\
\text { west }\end{array}$ & West & $\begin{array}{c}\text { North- } \\
\text { east }\end{array}$ & South & $\begin{array}{l}\text { Mid- } \\
\text { west }\end{array}$ & West & $\begin{array}{c}\text { North- } \\
\text { east }\end{array}$ & South & $\begin{array}{l}\text { Mid- } \\
\text { west }\end{array}$ & West \\
\hline Liquefied Petroleum Gases (LPG) ...... & 11 & 39 & 28 & 22 & 11 & 39 & 28 & 23 & 10 & 39 & 28 & 23 \\
\hline Compressed Natural Gas (CNG) ....... & 16 & 28 & 15 & 41 & 19 & 27 & 16 & 38 & 19 & 28 & 15 & 37 \\
\hline Liquefied Natural Gas (LNG) . . . . . . . & 0 & 82 & 2 & 17 & 1 & 77 & 2 & 21 & 1 & 78 & 2 & 20 \\
\hline Methanol, 85 Percent $^{a}$ (M85) .. & 4 & 6 & 5 & 85 & 5 & 7 & 6 & 82 & 4 & 6 & 5 & 84 \\
\hline Methanol, Neat (M100). & 42 & 7 & 0 & 51 & 42 & 7 & 0 & 51 & 42 & 7 & 0 & 51 \\
\hline Ethanol, 85 Percent $^{a}$ (E85) & - & 6 & 90 & 3 & * & 10 & 85 & 5 & * & 9 & 86 & 5 \\
\hline Ethanol, 95 Percent $^{\mathrm{a}}$ (E95) & 0 & 0 & 8 & 92 & 0 & 0 & 6 & 94 & 0 & 0 & 6 & 94 \\
\hline Electricity .... & 13 & 19 & 10 & 57 & 12 & 22 & 10 & 55 & 12 & 20 & 9 & 59 \\
\hline Total .... . & 11 & 37 & 25 & 27 & 12 & 36 & 25 & 27 & 12 & 37 & 24 & 27 \\
\hline
\end{tabular}

${ }^{a}$ The remaining portion of 85 -percent methanol and both ethanol fuels is gasoline. Consumption data include the gasoline portion of the fuel.

* Less than 0.5 percent rounded to 0 .

Note: Estimates for 1996 and 1997 have been revised. Estimates for 1997 are preliminary and those for 1998, in italics, are based on plans or projections. Estimates for historical years may be revised in future reports if new information becomes available.

Source: Energy Information Administration, Office of Coal, Nuclear, Electric, and Alternate Fuels.

mix of vehicle types by region are apparent for some fuels. For example, while 78 percent of the M85 vehicles in 1996 were located in the West, 85 percent of M85 consumption occurred there. This reflects the larger proportion of heavy-duty M85 vehicles, particularly transit buses, in the West. Overall, no major regional shifts are expected to take place between 1996 and 1998. The Northeast and Midwest are expected to gain slightly larger shares of CNG consumption, while the South's share is expected to decline. LNG consumption is expected to grow slightly more in the West between 1996 and 1998, primarily due to new LNG vehicle programs in California that began in late 1996 and early 1997. The Midwest will continue to be the largest region for ethanol consumption, but the West and South regions are expected to see small gains.

A changing mix of heavy- and light-duty AFV's appears to have the most influence on the growth rate of ATF consumption. Because of their much larger per vehicle fuel consumption, heavy-duty vehicles play a large role in ATF consumption. In 1996, heavy-duty vehicles comprised 18 percent of total AFV's, yet consumption by heavy-duty vehicles accounted for 55 percent of total ATF consumption. This effect is particularly noticeable for ethanol consumption (Table 12). E95 vehicles, which are all heavy-duty vehicles, are estimated to consume more ATF than light-duty E85 vehicles, even though E85 vehicles greatly outnumber E95 vehicles.

The effect of heavy-duty vehicles is also illustrated in Figure 11. The implied consumption of ATF per vehicle is derived by dividing fuel consumption (Table 10) by the number of vehicles (Table 1) in each fuel group. The fuel types with the largest percentages of heavy-duty vehicles have the largest ATF consumption per vehicle. Of the heavy-duty AFV's, transit buses and the heaviest trucks (over 26,000 pounds) consume the most fuel. School buses and what are sometimes referred to as medium-duty trucks $(8,500-26,000$ pounds) travel fewer miles and consume less fuel. The types of heavy-duty vehicles, therefore, accounts for the differences in per vehicle fuel consumption of those groups with large percentages of heavy-duty vehicles.

The changing distribution of AFV's by ownership has a small impact on fuel consumption growth, primarily because government vehicles tend to operate fewer miles than private sector vehicles. The relative distribution of ATF consumption by type of owner is similar to the distribution of AFV's (Table 13). In 1996, the Federal Government accounted for 2 percent of ATF consumption and 7 percent of AFV's. State and local governments accounted for 17 percent of consumption and operated 22 percent of the AFV's. Private entities accounted for 81 percent of consumption while operating 71 percent of the AFV's. A small shift in consumption by ownership group will occur as the Federal sector continues to retire its older AFV's. By 1998, the Federal government's share of AFV consumption is expected to be just under 2 percent while the private sector share will be 78 percent. The State and local government sector, however, is expected to increase its share to 20 percent of ATF consumption.

In the future, consumption of ATF's in the United States will respond to changes in the AFV inventory, but not always to the same degree. A potentially large increase in AFV's, expected to occur when the large numbers of flexible-fuel E85 vehicles that have been announced are 
Table 12. Estimated Consumption of Alternative Transportation Fuels in the United States, by Fuel and Vehicle Weight, 1994, 1996, and 1998

(Thousand Gasoline-Equivalent Gallons)

\begin{tabular}{|c|c|c|c|c|c|c|c|c|c|}
\hline Fuel & $\begin{array}{l}\text { Light } \\
\text { Duty }\end{array}$ & $\begin{array}{c}\text { Heavy } \\
\text { Duty }\end{array}$ & Total & $\begin{array}{l}\text { Light } \\
\text { Duty }\end{array}$ & $\begin{array}{c}\text { Heavy } \\
\text { Duty }\end{array}$ & Total & $\begin{array}{l}\text { Light } \\
\text { Duty }\end{array}$ & $\begin{array}{l}\text { Heavy } \\
\text { Duty }\end{array}$ & Total \\
\hline Liquefied Petroleum Gases (LPG) . . . . . & 110,936 & 137,531 & 248,467 & 104,934 & 134,224 & 239,158 & 111,662 & 141,319 & 252,981 \\
\hline Compressed Natural Gas (CNG) ...... & 15,490 & 8,670 & 24,160 & 24,462 & 22,461 & 46,923 & 34,584 & 40,414 & 74,998 \\
\hline Liquefied Natural Gas (LNG) . . . . . . . & 25 & 2,320 & 2,345 & 56 & 3,191 & 3,247 & 114 & 4,976 & 5,090 \\
\hline Ethanol, 85 Percent $^{2}$ (E85) $\ldots$ & 80 & 0 & 80 & 694 & 0 & 694 & 1,614 & 0 & 1,614 \\
\hline Ethanol, 95 Percent $^{a}$ (E95) $\ldots \ldots \ldots$ & * & 140 & 140 & 0 & 2,699 & 2,699 & 0 & 2,628 & 2,628 \\
\hline Electricity $\ldots \ldots \ldots \ldots \ldots \ldots \ldots$ & 280 & 150 & 430 & 495 & 278 & 773 & 711 & 356 & 1,067 \\
\hline$\ldots \ldots \ldots \ldots \ldots \ldots$ & 129,101 & 152,051 & 281,152 & 134,026 & 163,205 & 297,231 & 152,512 & 190,045 & 342,557 \\
\hline
\end{tabular}

${ }^{a}$ The remaining portion of 85 -percent methanol and both ethanol fuels is gasoline. Consumption data include the gasoline portion of the fuel.

* Less than 0.5 thousand gasoline-equivalent gallons.

Notes: Fuel quantities are expressed in a common base unit of gasoline-equivalent gallons to allow comparisons of different fuel types. Gasolineequivalent gallons do not represent gasoline displacement. Gasoline equivalent is computed by dividing the lower heating value of the alternative fuel by the lower heating value of gasoline and multiplying this result by the alternative fuel consumption value. Lower heating value refers to the Btu content per unit of fuel excluding the heat produced by condensation of water vapor in the fuel. Totals may not equal sum of components due to independent rounding. Estimates for historical years may be revised in future reports if new information becomes available. Estimates for 1996 have been revised. Estimates for 1998, in italics, are based on plans or projections.

Sources: 1994: Energy Information Administration, Office of Coal, Nuclear, Electric, and Alternate Fuels, and Science Applications International Corporation, "Alternative Transportation Fuels and Vehicles Data Development," unpublished final report prepared for the Energy Information Administration (McLean, VA, August 1995). 1996 and 1991: Energy Information Administation, Office of Coal, Nuclear, Electric, and Alternate Fuels.

Figure 11. Implied ATF Consumption per Vehicle, 1996

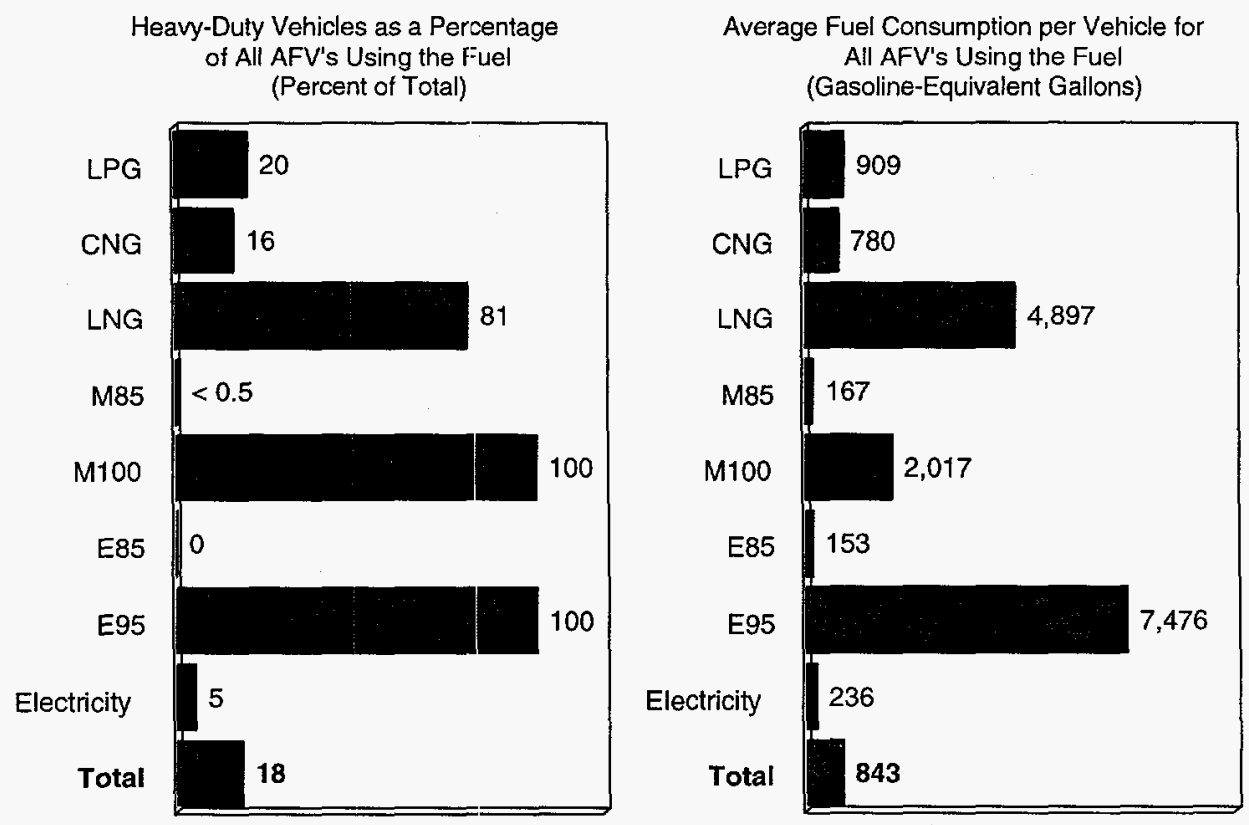

Source: Tables 1,7 , and 10. 
Table 13. Estimated Consumption of Alternative Transportation Fuels in the United States, by Vehicle Ownership, 1994, 1996, and 1998 (Thousand Gasoline-Equivalent Gallons)

\begin{tabular}{|c|c|c|c|c|c|c|c|c|c|c|c|c|}
\hline \multirow[b]{2}{*}{ Fuel } & \multicolumn{4}{|c|}{1994} & \multicolumn{4}{|c|}{1996} & \multicolumn{4}{|c|}{1998} \\
\hline & Federal & $\begin{array}{c}\text { State and } \\
\text { Local }\end{array}$ & Private & Total & Federal & $\begin{array}{c}\text { State and } \\
\text { Local }\end{array}$ & Private & Total & Federal & $\begin{array}{c}\text { State and } \\
\text { Local }\end{array}$ & Private & Total \\
\hline Liquefied Petroleum Gases (LPG) & 17 & 26,547 & 221,903 & 248,467 & 58 & 25,366 & 213,734 & 239,158 & 111 & 27,393 & 225,477 & 252,981 \\
\hline Compressed Natural Gas (CNG) & 1,990 & 8,060 & 14,110 & 24,160 & 4,572 & 18,449 & 23,902 & 46,923 & 4,642 & 33,154 & 37,202 & 74,998 \\
\hline Liquefied Natural Gas (LNG) & 7 & 2,289 & 49 & 2,345 & 88 & 2,735 & 424 & 3,247 & 135 & 4,256 & 699 & 5,090 \\
\hline Methanol, 85 Percent $^{\mathrm{a}}$ (M85) & 1,090 & 330 & 920 & 2,340 & 950 & 744 & 1,696 & 3,390 & 586 & 913 & 2,333 & 3,832 \\
\hline Methanol, Neat (M100) & 0 & 3,190 & * & 3,190 & 0 & 347 & 0 & 347 & 0 & 347 & 0 & 347 \\
\hline Ethanol, 85 Percent ${ }^{\mathrm{a}}$ (E85) & 20 & 50 & 10 & 80 & 217 & 284 & 193 & 694 & 513 & 636 & 465 & 1,614 \\
\hline Ethanol, 95 Percent $^{\mathrm{a}}$ (E95) & 0 & 130 & 10 & 140 & 0 & 2,628 & 71 & 2,699 & 0 & 2,628 & 0 & 2,628 \\
\hline Electricity & 8 & 142 & 280 & 430 & 38 & 248 & 487 & 773 & 61 & 336 & 670 & 1,067 \\
\hline Total $\ldots \ldots \ldots \ldots \ldots \ldots \ldots$ & 3,132 & 40,738 & 237,282 & 281,152 & 5,923 & 50,801 & 240,507 & 297,231 & 6,048 & 69,663 & 266,846 & 342,557 \\
\hline
\end{tabular}

${ }^{a}$ The remaining portion of 85 -percent methanol and both ethanol fuels is gasoline. Consumption data include the gasoline portion of the fuel.

* Less than 0.5 thousand gasoline-equivalent gallons.

Notes: Fuel quantities are expressed in a common base unit of gasoline-equivalent gallons to allow comparisons of different fuel types. Gasoline-equivalent gallons do not represent gasoline

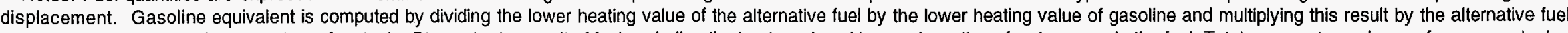

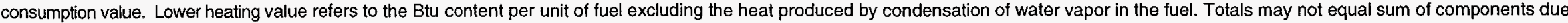

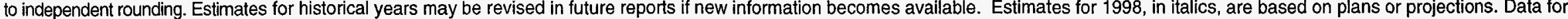
1994 and 1996 have been revised.

Sources: 1994: Energy Information Administration, Office of Coal, Nuclear, Electric, and Alternate Fuels, and Science Applications International Corporation, "Alternative Transportation Fuels and

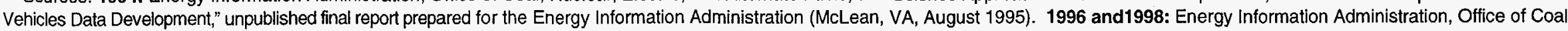
Nuclear, Electric, and Alternate Fuels. 


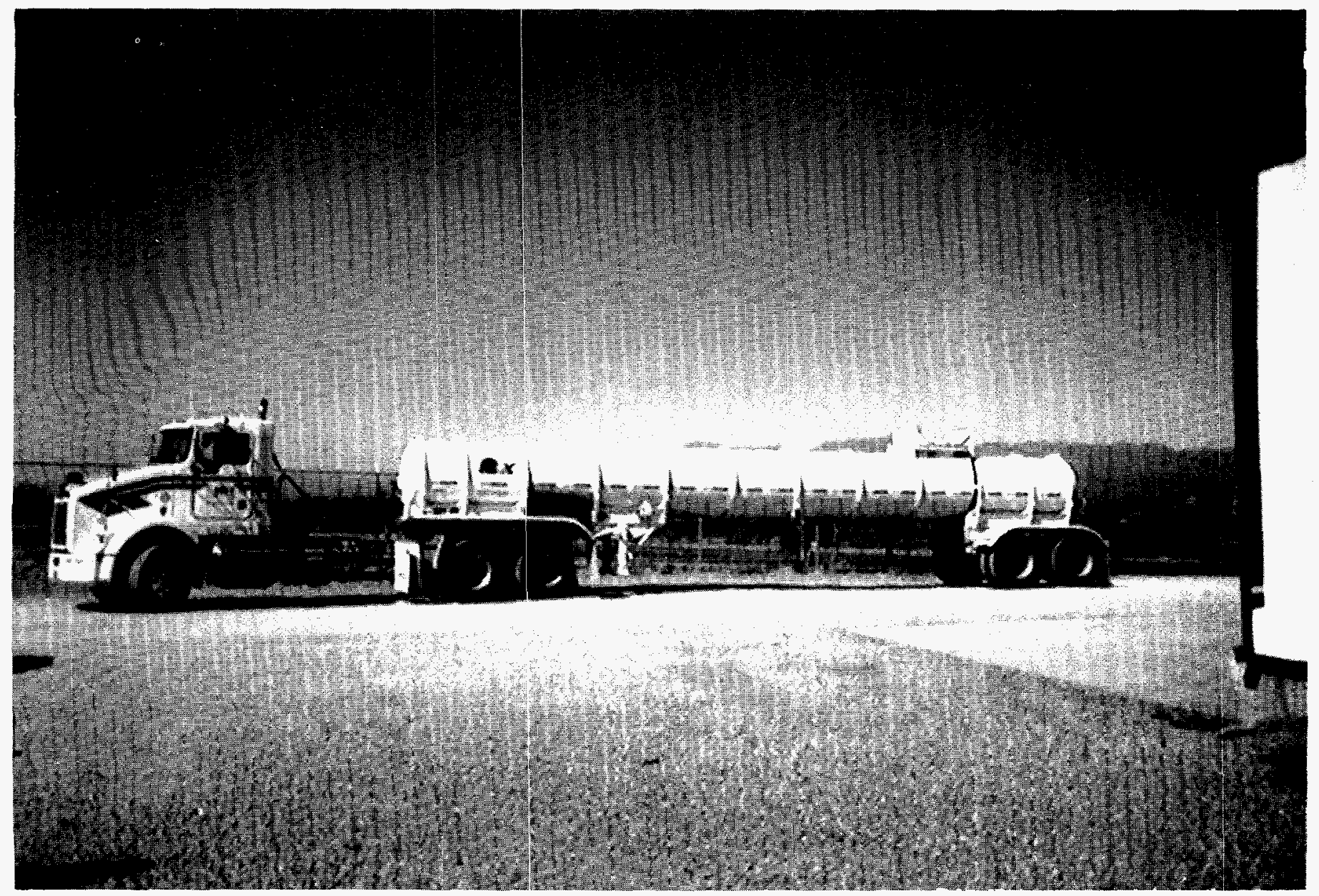

Jack B. Kelley, Inc. Kenworth T800B LNG truck hauling acid with MC 312 trailer.

made available, is not expected to result in equivalent increases in ATF consumption. If electric vehicles gain market share as a result of ZEV mandates, ATF consumption would tend to grow more slowly, because electric vehicles travel fewer miles and consume less fuel than other types of AFV's. New tax structures for some alternative fuels could cause increases in their use.

\section{Oxygenates}

Oxygenate consumption (on a gasoline-equivalent-gallon basis) increased 82 percent from 1992 to 1996 and is expected to increase another 8 percent from 1996 to 1998. The largest year-to-year increases occurred between 1992 and 1993, when oxygenated gasoline requirements were instituted and from 1994 to 1995, when reformulated gasoline (RFG) requirements went into effect. Since 1995, oxygenate consumption has leveled off somewhat, as requirements for oxygenated gasoline were eliminated or reduced in several cities and few areas elected to opt in to the RFG program.
Since the introduction of RFG mandates, the proportion of oxygenates in the U.S. gasoline supply has increased greatly. In 1992, oxygenates comprised 1.7 percent, on a gasoline-equivalent-gallon basis, of the gasoline consumed. By 1995, oxygenates accounted for 3.1 percent of gasoline supplied. In 1996, oxygenate consumption declined 5.0 percent as high corn prices drove up the price of ethanol and discouraged ethanol blending. Oxygenate consumption rebounded in 1997 and is expected to increase again in 1998. By 1998, oxygenates are expected to account for about the same share of gasoline as in 1995 (3.0 percent).

MTBE continues to be the largest oxygenate in use, followed by ethanol. A very small amount of other alcohols and ethers are in use. Between 1992 and 1995, the ratio of MTBE consumption to total oxygenate consumption has ranged between 63 percent and 75 percent. In 1996, MTBE accounted for 81 percent of oxygenates consumed. By 1998, it is expected to decline to 77 percent. 


\section{Biodiesel and Hydrogen}

The data in this report focus on the most developed ATF's and replacement fuels. However, there are several other alternative or replacement fuels in various stages of development. Biodiesel fuel, for instance, saw increased testing and demonstration, particularly in heavy-duty and farm applications in 1996 and 1997. Biodiesel is usually made from soybean or rapeseed oil and is most often mixed with diesel fuel in a ratio of 20 percent biodiesel to 80 percent diesel fuel (B20). As a neat fuel (100 percent biodiesel, also known as B100), biodiesel was designated an alternative fuel in 1996. B20 has not been designated as an alternative fuel under EPACT, but the biodiesel portion of B20 is considered a replacement fuel, like the oxygenates. A petition has been filed with the Department of Energy (DOE) to define B20 as an alternative fuel. The petition is currently being reviewed.

Hydrogen is another ATF under development. It has been used in a few test vehicles, but is more widely considered as a potential fuel in fuel cell applications. Much research on fuel cells is currently ongoing.

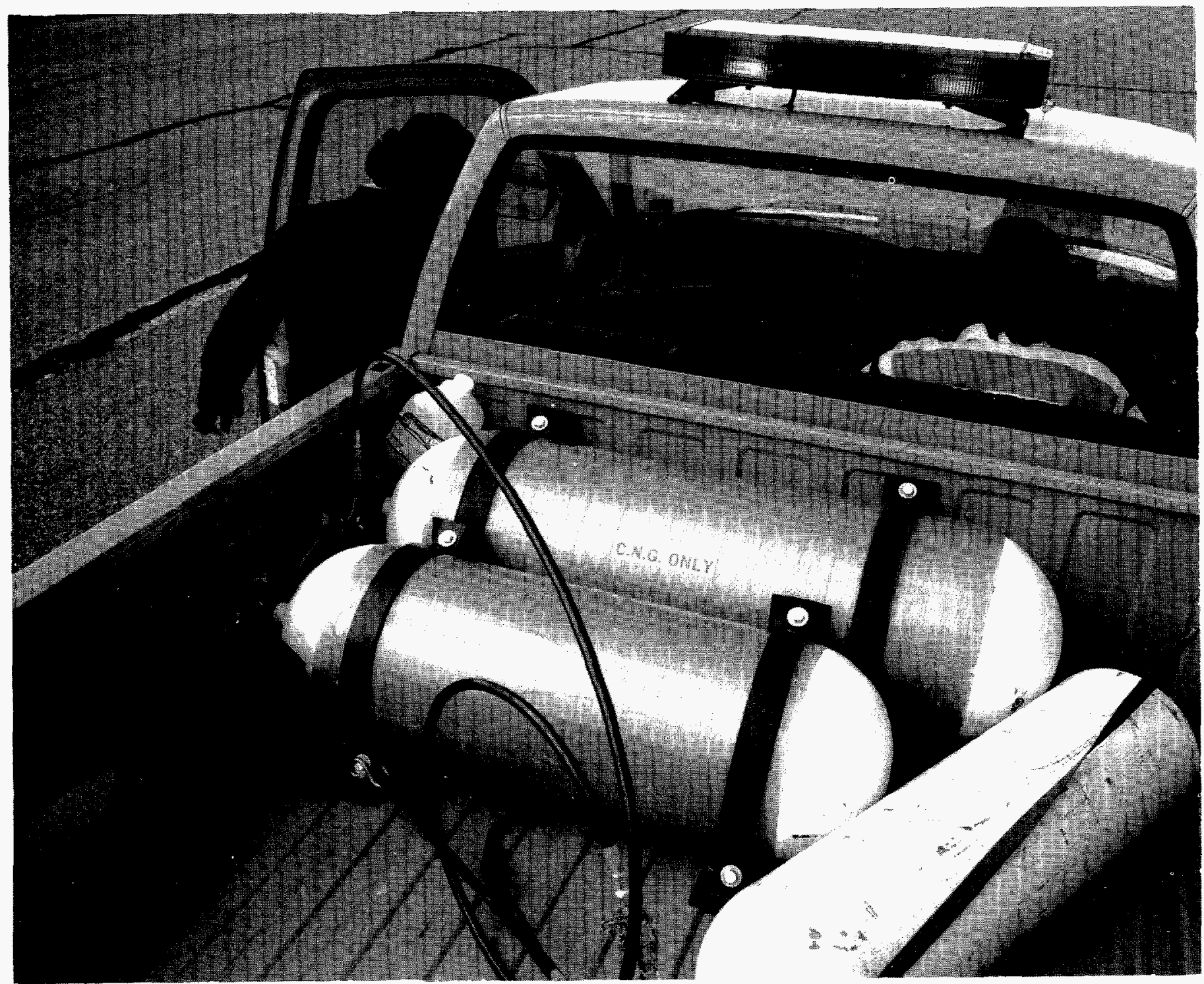

These light-weight high-strength compressed natural gas storage tanks are similar to those needed for compressed hydrogen. 



\section{Alternative-Fueled Vehicles Made Available}

Information in this chapter on alternative-fueled vehicles (AFV's) made available is based on EIA's 1996 "Alternative Fuel Vehicle Suppliers' Annual Report," Form EIA-886. The nationwide survey of 1,389 AFV suppliers was conducted during early 1997, with a 100 percent response rate. Three hundred and four new respondents were canvassed in 1997. Since last year's survey was conducted, 49 companies merged and 51 companies are no longer in the AFV business. Overall, in excess of 300 companies surveyed last year were determined to be "out of scope" to the survey, because they did not expect to supply AFV's.

In summary, 51 original equipment manufacturers (OEM's) and 319 aftermarket conversion companies supplied a total of 92,185 AFV's $(24,465$ onroad AFV's and 67,720 nonroad AFV's) in 1996 (Tables 14 and 15). Information for AFV's made available in 1995 has been revised since last year's issue of this report. The revised data are shown in Appendix D.

\section{Onroad AFV's Made Available in 1996}

For 1996, onroad vehicles made up 27 percent of the total AFV's made available, or 24,465 vehicles (Table 14). CNG vehicles accounted for more than two-fifths of onroad AFV's made available in 1996. LPG vehicles accounted for one-third, while alcohol vehicles (M85, M100 and E85) comprised more than one-fifth of total onroad AFV's made available. In examining the AFV's by vehicle configuration, ${ }^{21}$ bi-fueled CNG and LPG vehicles accounted for more than 40 percent of onroad vehicles in 1996. By weight class, light-duty vehicles (i.e., gross vehicle weight under 8,500 pounds) accounted for nearly 70 percent, with heavy-duty vehicles providing the balance. Three-fifths of onroad AFV's made available were "nondedicated" vehicles (i.e., capable of operating on more than one fuel), while the remainder were dedicated (single fuel) vehicles.

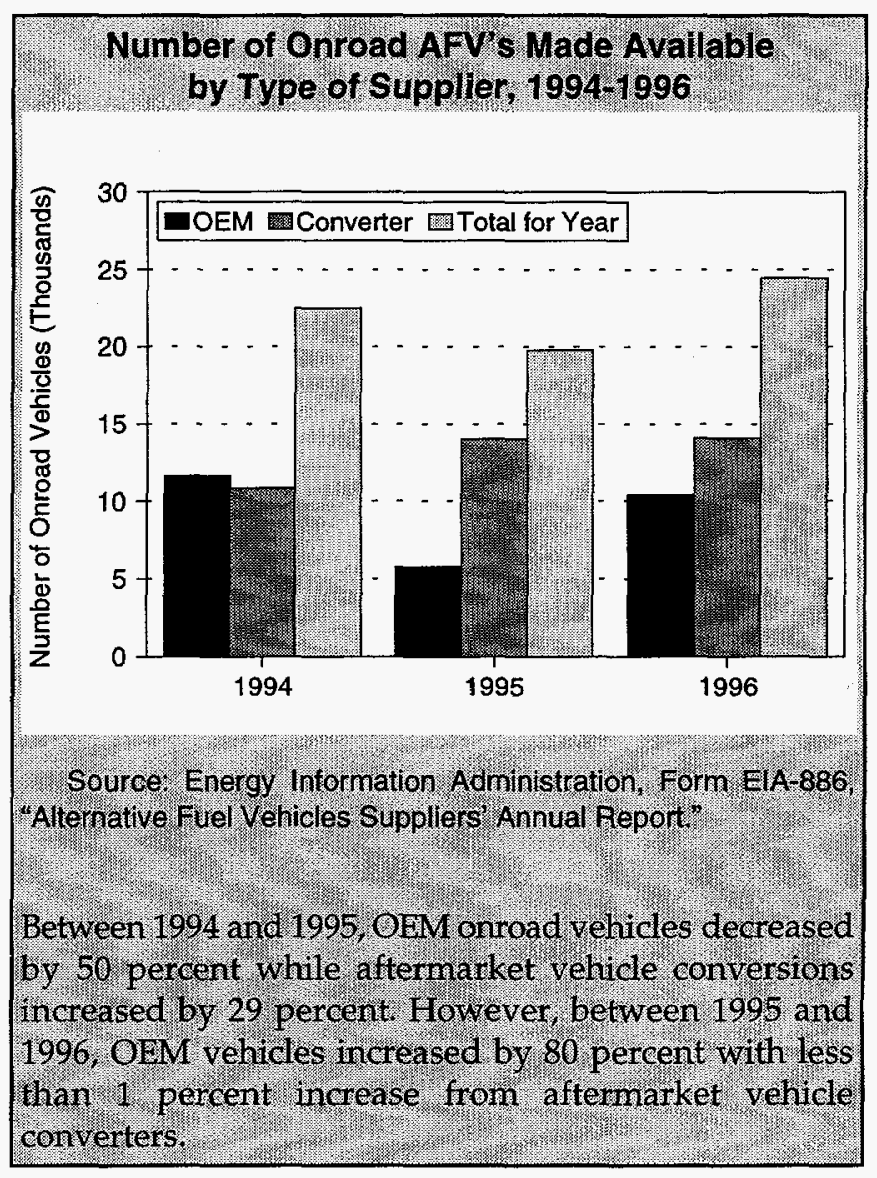

\section{Compressed Natural Gas (CNG) Vehicles}

In $1996,10,634$ onroad CNG vehicles were made available. Bi-fueled automobiles, cargo vans, pickups, and other trucks were responsible for nearly 70 percent of the CNG total. CNG vehicles provided by OEM's comprised more than one-fourth of total $\mathrm{CNG}$ onroad vehicles made available, and 12 percent of total onroad AFV's made available. Aftermarket vehicle converters were responsible for more than 50 percent of CNG onroad vehicles made available in 1996 and 30 percent of all onroad AFV's made available.

\footnotetext{
21 "Vehicle configuration" denotes the fuel use capabilities of the vehicle: e.g., dedicated (single fuel), dual-fueled, bi-fueled, etc. See Glossary for definitions of each vehicle configuration type.
} 
Table 14. Number of Onroad Alternative-Fueled Vehicles Made Available, by Fuel Type and Vehicle Configuration, 1996

\begin{tabular}{|c|c|c|c|c|c|c|c|}
\hline Fuel Type & Automobiles & $\begin{array}{c}\text { Passenger } \\
\text { Vans }\end{array}$ & $\begin{array}{c}\text { Cargo } \\
\text { Vans/ } \\
\text { Pickups } \\
\end{array}$ & $\begin{array}{l}\text { Other } \\
\text { Trucks }\end{array}$ & Buses & $\begin{array}{c}\text { Other } \\
\text { Onroad } \\
\text { Vehicles }\end{array}$ & Total \\
\hline Liquefied Petroleum Gas (LPG). . . . . & 1,158 & 238 & 2,221 & 3,506 & 564 & 28 & 7,715 \\
\hline Dedicated $\ldots \ldots \ldots \ldots \ldots \ldots$ & 390 & 70 & 524 & 3,294 & 480 & 18 & 4,776 \\
\hline Nondedicated $\ldots \ldots \ldots \ldots \ldots$ & 768 & 168 & 1,697 & 212 & 84 & 10 & 2,939 \\
\hline Compressed Natural Gas (CNG) ... & 2,764 & 599 & 4,083 & 2,054 & 1,125 & 9 & 10,634 \\
\hline Dedicated $\ldots \ldots \ldots \ldots \ldots \ldots$ & 411 & 357 & 600 & 179 & 926 & 9 & 2,482 \\
\hline Nondedicated $\ldots \ldots \ldots \ldots \ldots$ & 2,353 & 242 & 3,483 & 1,875 & 199 & 0 & 8,152 \\
\hline Liquefied Natural Gas (LNG) ..... & 0 & 0 & 33 & 29 & 12 & 0 & 74 \\
\hline Dedicated $\ldots \ldots \ldots \ldots \ldots \ldots \ldots$ & 0 & 0 & 0 & 26 & 12 & 0 & 38 \\
\hline Nondedicated $\ldots \ldots \ldots \ldots \ldots$ & 0 & 0 & 33 & 3 & 0 & 0 & 36 \\
\hline Methanol, 85 percent $^{a}$ (M85) & 2,011 & 0 & 0 & 0 & 0 & 0 & 2,011 \\
\hline Dedicated $\ldots \ldots \ldots \ldots \ldots \ldots \ldots$ & 0 & 0 & 0 & 0 & 0 & 0 & 0 \\
\hline Nondedicated $\ldots \ldots \ldots \ldots \ldots$ & 2,011 & 0 & 0 & 0 & 0 & 0 & 2,011 \\
\hline Methanol, Neat (M100) & 0 & 0 & 0 & 0 & 60 & 0 & 60 \\
\hline Dedicated ................. & 0 & 0 & 0 & 0 & 60 & 0 & 60 \\
\hline Nondedicated $\ldots \ldots \ldots \ldots \ldots$ & 0 & 0 & 0 & 0 & 0 & 0 & 0 \\
\hline Ethanol, 85 percent $^{\mathrm{a}}(\mathrm{E} 85) \ldots \ldots \ldots$ & 3,273 & 0 & 0 & 0 & 0 & 0 & 3,273 \\
\hline Dedicated $\ldots \ldots \ldots \ldots \ldots \ldots \ldots$ & 0 & 0 & 0 & 0 & 0 & 0 & 0 \\
\hline Nondedicated $\ldots \ldots \ldots \ldots \ldots$ & 3,273 & 0 & 0 & 0 & 0 & 0 & 3,273 \\
\hline Ethanol, 95 percent $^{\mathrm{a}}$ (E95) $\ldots \ldots \ldots$ & 0 & 0 & 0 & 0 & 0 & 0 & 0 \\
\hline Dedicated $\ldots \ldots \ldots \ldots \ldots \ldots \ldots$ & 0 & 0 & 0 & 0 & 0 & 0 & 0 \\
\hline Nondedicated $\ldots \ldots \ldots \ldots \ldots$ & 0 & 0 & 0 & 0 & 0 & 0 & 0 \\
\hline Electricity & 370 & 2 & 84 & 62 & 146 & 29 & 693 \\
\hline Nonhybrid & 369 & 2 & 83 & 62 & 144 & 29 & 689 \\
\hline Hybrid ..................... & 1 & 0 & 1 & 0 & 2 & 0 & 4 \\
\hline Other $^{b}$ & 0 & 0 & 0 & 0 & 5 & 0 & 5 \\
\hline Dedicated. & 0 & 0 & 0 & 0 & 0 & 0 & 0 \\
\hline Nondedicated & 0 & 0 & 0 & 0 & 5 & 0 & 5 \\
\hline Total . & 9,576 & 839 & 6,421 & 5,651 & 1,912 & 66 & 24,465 \\
\hline Dedicated and Nonhybrid . . . . . . . & 1,170 & 429 & 1,207 & 3,561 & 1,622 & 56 & 8,045 \\
\hline Nondedicated and Hybrid $\ldots \ldots \ldots$ & 8,406 & 410 & 5,214 & 2,090 & 290 & 10 & 16,420 \\
\hline
\end{tabular}

${ }^{\text {a } T h e ~ r e m a i n i n g ~ p o r t i o n ~ o f ~ 85-p e r c e n t ~ m e t h a n o l ~ a n d ~ b o t h ~ e t h a n o l ~ f u e l s ~ i s ~ g a s o l i n e . ~}$

bincludes hydrogen, neat biodiesel, and other alternative fuels.

Notes: - Vehicles made available are vehicles that are completed and made available for delivery to dealers or users in a given year. Dedicated vehicles and nonhybrid electric vehicles are designed to operate exclusively on one alternative fuel. - Nondedicated vehicles and hybrid electric vehicles are configured to operate on more than one fuel, usually an alternative fuel and gasoline or diesel fuel. - Data are based on survey responses as of August 31, 1997. Data for 1996 have been revised.

Source: Energy Information Administration, Form EIA-886, "Alternative Fuel Vehicle Suppliers' Annual Report." 
Table 15. Number of Nonroad Alternative-Fueled Vehicles Made Available in 1996, and Planned to be Made Available in 1997, by Fuel Type

\begin{tabular}{|c|c|c|}
\hline Fuel Type & 1996 & 1997 \\
\hline Liquefied Petroleum Gas (LPG) ... & 34,559 & 31,212 \\
\hline Compressed Natural Gas (CNG) .. & 497 & 382 \\
\hline Liquefied Natural Gas (LNG) . . . . & 4 & 0 \\
\hline Methanol, 85 percent $^{\mathrm{a}}$ (M85) $\ldots .$. & 0 & 0 \\
\hline Methanol, Neat $(M 100) \ldots \ldots \ldots$ & 0 & 0 \\
\hline Ethanol, 85 percent $^{a}$ (E85) & 0 & 0 \\
\hline Ethanol, 95 percent $^{a}$ (E95) & 0 & 0 \\
\hline Electricity .... & 32,660 & 36,523 \\
\hline Other $^{\mathrm{b}} \ldots \ldots$ & 0 & 0 \\
\hline Total . & 67,720 & 68,117 \\
\hline
\end{tabular}

${ }^{a}$ The remaining portion of 85-percent methanol and both ethanol fuels is gasoline.

${ }^{b}$ Includes hydrogen, neat biodiesel, and other alternative fuels.

Notes: - Nonroad vehicles are vehicles designed for offroad operation and used for industrial or commercial purposes. They include forklifts, agricultural and construction vehicles, and others. - Vehicles made available are vehicles that are completed and made available for delivery to dealers or users in a given year. - Data are based on survey responses as of August 31, 1997. Data for 1996 has been revised.

Source: Energy information Administration, Form ElA-886, "Alternative Fuel Vehicle Suppliers' Annual Report."
Between 1995 and 1996, the number of CNG vehicles made available increased by more than 300 vehicles. Automobiles increased by nearly 800 vehicles, other trucks by more than 1,300 , and buses by several hundred vehicles. Fewer CNG vans (decrease of 1,500) and other onroad vehicles were made available in 1996 than 1995. Although the number of CNG vehicles made available appeared to have increased substantially (51 percent) between 1994 and 1996 (Table 16), this increase is largely the result of improved survey coverage in 1995.

\section{Liquefied Petroleum Gas (LPG) Vehicles}

LPG vehicles accounted for over 30 percent of onroad AFV's made available in 1996. OEMs provided 21 percent of these LPG vehicles and 7 percent of all onroad AFV's made available. Conversions were responsible for over 70 percent of LPG's onroad vehicle total and 25 percent of the total for onroad AFV's made available. LPG's bi-fueled vehicles accounted for 34 percent of the LPG onroad total, with bi-fueled cargo vans and pickups alone accounting for 21 percent. Between 1995 and 1996, total LPG vehicles made available increased by more than 600 . Automobiles increased by 375 vehicles, and buses by nearly 400 vehicles. In contrast, cargo vans, pickups, and other onroad vehicles declined by more than 400 vehicles.

\section{Alcohol-fueled Vehicles}

The number of ethanol- and methanol-fueled vehicles made available rose sharply between 1995 and 1996. In

Table 16. Number of Onroad Alternative-Fueled Vehicles Made Available, by Fuel Type, 1994-1996

\begin{tabular}{|c|c|c|c|}
\hline Fuel Type & 1994 & 1995 & 1996 \\
\hline Liquefied Petroleum Gas (LPG). . . . . . . . . & 7,041 & 7,080 & 7,715 \\
\hline Compressed Natural Gas (CNG) ......... & 7,048 & 10,292 & 10,634 \\
\hline Liquefied Natural Gas (LNG) & 96 & 85 & 74 \\
\hline Methanol, 85 percent $^{\mathrm{a}}$ (M85) & $w$ & 1,335 & 2,011 \\
\hline Methanol, Neat $(M 100) \ldots \ldots \ldots \ldots \ldots$ & 0 & 0 & 60 \\
\hline Ethanol, 85 percent $^{a}(E 85) \ldots \ldots \ldots \ldots \ldots$ & 0 & 430 & 3,273 \\
\hline Ethanol, 95 percent $^{\text {a }}$ (E95) & 0 & 0 & 0 \\
\hline Electricity .... & 636 & 553 & 693 \\
\hline Other ${ }^{b}$. & $w$ & 8 & 5 \\
\hline Total $\ldots \ldots \ldots \ldots \ldots \ldots \ldots \ldots \ldots \ldots$ & 22,463 & 19,783 & 24,465 \\
\hline
\end{tabular}

${ }^{a}$ The remaining portion of 85-percent methanol and both ethanol fuels is gasoline.

Includes hydrogen, biodiesel, and other alternative fuels.

Notes: - Vehicles made available are vehicles that are completed and made available for delivery to dealers or users in a given year. - Dedicated vehicles and nonhybrid electric vehicles are designed to operate exclusively on one alternative fuel. - Nondedicated vehicles and hybrid electric vehicles are configured to operate on more than one fuel, usually an alternative fuel and gasoline or diesel fuel. - Data are based on survey responses as of August 31, 1997. Data for 1995 and 1996 have been revised.

Source: Energy Information Administration, Form EIA-886, "Alternative Fuel Vehicle Suppliers' Annual Report." 
particular, the number of E85 vehicles made available increased from 430 to nearly 3,300 .

The information collected on Form EIA-886 regarding AFV's made available in 1996 does not indicate any E95 vehicles were made available. However, information provided in Chapter 2 on AFV inventories suggests that there were a number of new E95 buses placed in service during 1996. The explanation for this anomaly is that the Los Angeles Metropolitan Transit Authority converted several of its transit buses from methanol to ethanol. This conversion was not reported on the Form ELA-886.

\section{Nonroad AFV's Made Available in 1996}

In 1996, 67,720 nonroad AFV's were made available (Table 15), or 73 percent of total AFV's made available. Dedicated LPG vehicles accounted for just over half of nonroad AFV's, while battery-powered vehicles represented 48 percent of total nonroad AFV's. OEM's provided nearly all ( 99 percent) nonroad AFV's made available in 1996. By vehicle type, forklifts and industrial vehicles accounted for more than 90 percent of nonroad AFV's.

\section{Outlook-AFV's Expected to be Made Available in 1997}

The total number of AFV's planned to be made available in 1997 is 201,207. Two-thirds of these AFV's are expected to be onroad vehicles (Table 17). Nonroad AFV's are expected to account for the balance, around 68,000 vehicles.

The surge in AFV's planned to be made available is due to announced OEM plans to produce one or more whole vehicle lines (e.g., certain minivans) as E85 vehicles.

Between 1996 and 1997, the remaining onroad AFV's have the following outlook: CNG vehicles made available are expected to increase by 37 percent; LPG vehicles made available by 60 percent; and electric vehicles made available by almost 600 percent. Light-duty vehicles will account for 94 percent of the planned to be made available onroad AFV's in 1997.

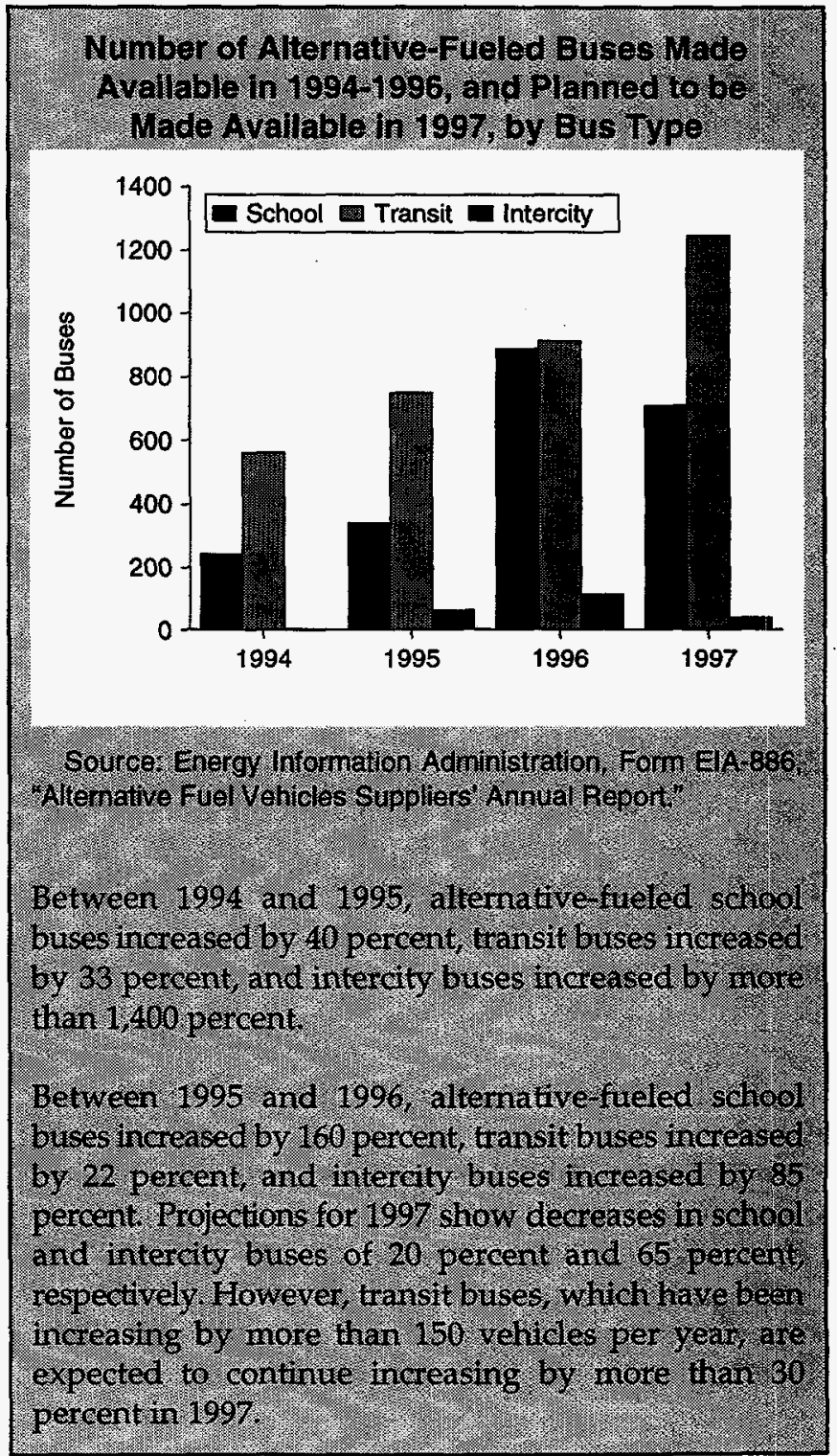


Table 17. Number of Onroad Alternative-Fueled Vehicles Planned to be Made Available, by Fuel Type and Vehicle Configuration, in 1997

\begin{tabular}{|c|c|c|c|c|c|c|c|}
\hline Fuel Type & Automobiles & $\begin{array}{c}\text { Passenger } \\
\text { Vans } \\
\end{array}$ & $\begin{array}{c}\text { Cargo } \\
\text { Vans/ } \\
\text { Pickups } \\
\end{array}$ & $\begin{array}{l}\text { Other } \\
\text { Trucks }\end{array}$ & Buses & $\begin{array}{c}\text { Other } \\
\text { Onroad } \\
\text { Vehicles }\end{array}$ & Total \\
\hline$\ldots \ldots \ldots \ldots$ & 2,492 & W & 4,434 & 3,775 & w & 0 & 12,368 \\
\hline Dedicated ..... & 102 & W & W & w & w & 0 & 3,549 \\
\hline Nondedicated $\ldots \ldots \ldots \ldots \ldots$ & 2,390 & W & $w$ & w & w & 0 & 8,819 \\
\hline Compressed Natural Gas (CNG) ... & 4,090 & 1,303 & 6,883 & 1,044 & 1,219 & 59 & 14,598 \\
\hline Dedicated $\ldots \ldots \ldots \ldots \ldots \ldots \ldots$ & w & w & W & 246 & 1,019 & w & 4,663 \\
\hline Nondedicated $\ldots \ldots \ldots \ldots \ldots$ & W & $w$ & W & 798 & 200 & W & 9,935 \\
\hline Liquefied Natural Gas (LNG) & 0 & 0 & $w$ & W & w & 0 & 234 \\
\hline Dedicated $\ldots \ldots \ldots \ldots \ldots \ldots \ldots$ & 0 & 0 & 0 & w & w & 0 & w \\
\hline Nondedicated $\ldots \ldots \ldots \ldots \ldots$ & 0 & 0 & W & $w$ & 0 & 0 & W \\
\hline Methanol, 85 percent $^{\mathrm{a}}$ (M85) & w & 0 & 0 & 0 & 0 & 0 & w \\
\hline Dedicated ............ & 0 & 0 & 0 & 0 & 0 & 0 & 0 \\
\hline Nondedicated & w & 0 & 0 & 0 & 0 & 0 & W \\
\hline Methanol, Neat $(M 100)$ & 0 & 0 & 0 & 0 & 0 & 0 & 0 \\
\hline Dedicated $\ldots \ldots \ldots \ldots \ldots \ldots \ldots$ & 0 & 0 & 0 & 0 & 0 & 0 & 0 \\
\hline Nondedicated $\ldots \ldots \ldots \ldots \ldots$ & 0 & 0 & 0 & 0 & 0 & 0 & 0 \\
\hline Ethanol, 85 percent $^{\mathrm{a}}$ (E85) & w & 0 & 0 & 0 & 0 & 0 & $w$ \\
\hline Dedicated & 0 & 0 & 0 & 0 & 0 & 0 & 0 \\
\hline Nondedicated & w & 0 & 0 & 0 & 0 & 0 & w \\
\hline Ethanol, 95 percent $^{\mathrm{a}}$ (E95) & 0 & 0 & 0 & 0 & 0 & 0 & 0 \\
\hline Dedicated $\ldots \ldots \ldots \ldots \ldots \ldots$ & 0 & 0 & 0 & 0 & 0 & 0 & 0 \\
\hline Nondedicated $\ldots \ldots \ldots \ldots \ldots \ldots$ & 0 & 0 & 0 & 0 & 0 & 0 & 0 \\
\hline Electricity & 2,870 & w & 1,436 & w & w & w & 4,835 \\
\hline Nonhybrid & $w$ & w & W & w & w & W & 4,803 \\
\hline Hybrid .... & W & 0 & W & 0 & w & 0 & 32 \\
\hline Other $^{\mathrm{b}}$ & w & 0 & $w$ & 0 & 11 & 0 & 25 \\
\hline Dedicated...... & w & 0 & W & 0 & w & 0 & w \\
\hline Nondedicated & 0 & 0 & 0 & 0 & w & 0 & W \\
\hline Total $\ldots \ldots \ldots \ldots \ldots \ldots \ldots$ & 17,493 & $\mathbf{w}$ & 12,771 & 5,134 & 1,991 & $\mathbf{w}$ & 133,090 \\
\hline Dedicated and Nonhybrid ........ & 3,681 & W & 3,413 & 3,470 & 1,196 & W & 13,108 \\
\hline Nondedicated and Hybrid . . . . . . . & 13,812 & W & 9,358 & 1,664 & 795 & W & 119,982 \\
\hline
\end{tabular}

${ }^{2}$ The remaining portion of 85-percent methanol and both ethanol fuels is gasoline.

Includes hydrogen, neat biodiesel, and other alternative fuels.

$W=$ Withheld to avoid disclosure of individual company data.

Notes: $\bullet$ Vehicles made available are vehicles that are completed and made available for delivery to dealers or users in a given year. $\bullet$ Dedicated vehicles and nonhybrid electric vehicles are designed to operate exclusively on one alternative fuel. $\bullet$ Nondedicated vehicles and hybrid electric vehicles are configured to operate on more than one fuel, usually an alternative fuel and gasoline or diesel fuel. - Data are based on survey responses as of August 31, 1997.

Source: Energy Information Administration, Form EIA-886, "Alternative Fuel Vehicle Suppliers' Annual Report." 


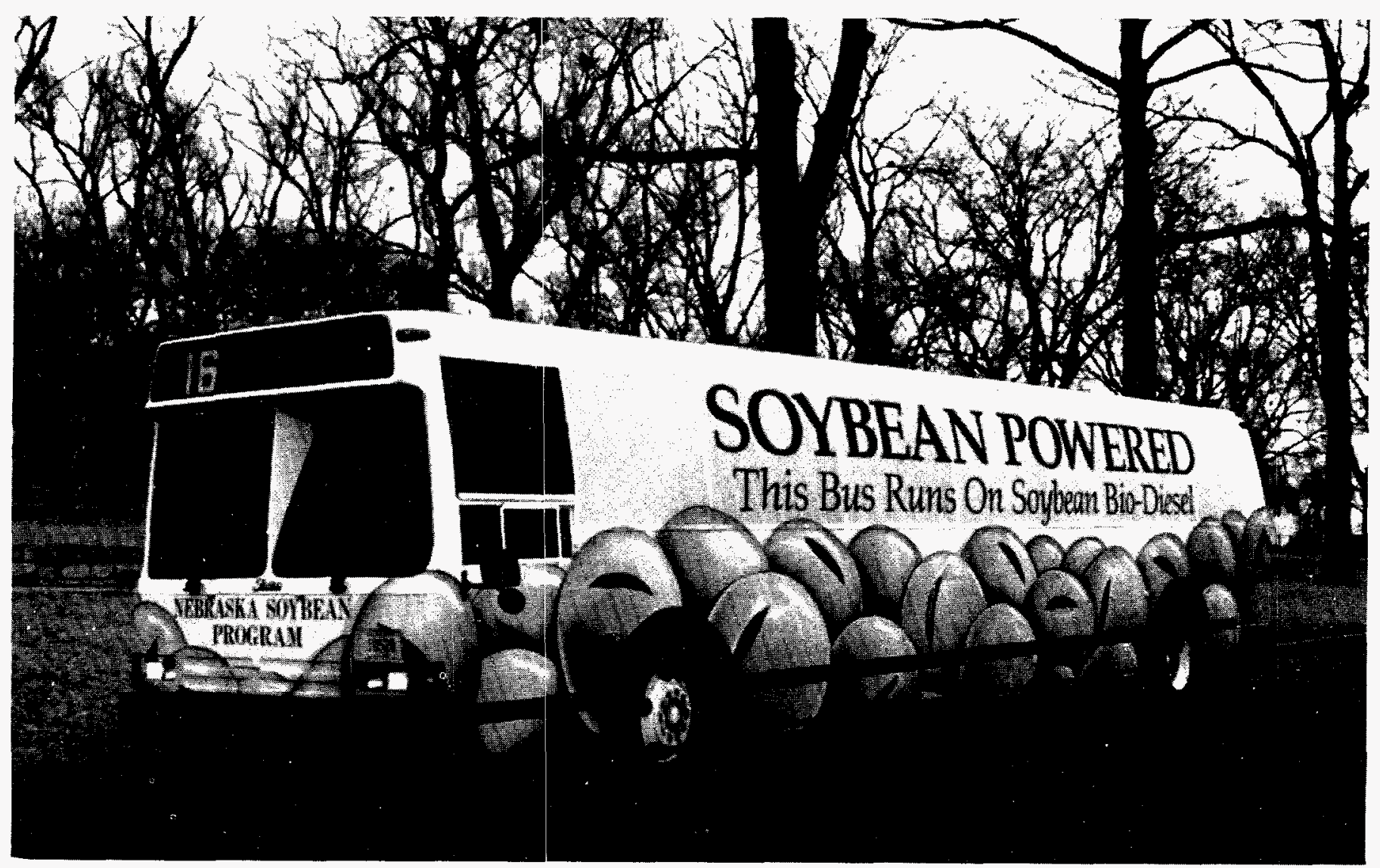

Alternative-Fueled Bus in Nebraska. 
Appendix A

Estimation Methods and Data Quality 



\section{Appendix A}

\section{Estimation Methods and Data Quality}

Estimation methods and data quality issues for alternative-fueled vehicle (AFV) inventories (Chapter 2) and alternative and replacement fuel consumption (Chapter 3) are presented in this appendix. This appendix also includes an explanation of the EIA-886 survey, which was used to collect data on alternative-fueled vehicles made available (Chapter 4). Alternatives to Traditional Transportation Fuels 1996 focuses on historical data for 1996 and projected or planned data for 1997 and 1998. For the most part, data for 1992 through 1995 are from Alternatives to Traditional Transportation Fuels 1995 and Alternatives to Traditional Transportation Fuels 1994-Volume 1. Any revisions to those data are explained in this report.

\section{Alternative-Fueled Vehicle Inventory}

The methods employed to estimate the number of AFV's in use (AFV inventories) vary by vehicle ownership category (Federal government, State and local government, or private) and by fuel type. In general, the best estimates for each vehicle category were made after an extensive search of available data sources. These sources included: State agencies, particularly State energy offices; the U.S. Department of Energy's (DOE's) Clean Cities program surveys and database; DOE's Alternative Fuels Data Center Web (AFDC) site and database; contacts with AFV associations such as the Natural Gas Vehicle Coalition and the Ethanol Vehicle Coalition; databases of the Federal Transit Administration (FTA) and American Public Transit Association (APTA); World Wide Web sites of various AFV stakeholders (e.g., State of California, Northeast Alternative Vehicle Consortium, San Diego Gas and Electric), and numerous pieces of industry literature. Publications providing information included:

- AFDC Update, a newsletter prepared for the U.S. Department of Energy, Alternative Fuels Data Center, by the National Renewable Energy Laboratory (NREL), (Golden, CO, Quarterly).

- Alternative Fuels in Trucking, a newsletter prepared by the Trucking Research Institute in cooperation with the U.S. Department of Energy, (Alexandria, VA, Quarterly).

- Clean Cities Drive, a newsletter prepared for the U.S. Department of Energy Clean Cities Program by the National Renewable Energy Laboratory (NREL), (Golden, CO, Quarterly).

- Federal Alternative Motor Fuels Programs Fifth Annual Report to Congress, U.S. Department of Energy, Office of Transportation Technologies, (September 1996).

- LNG Express Project Survey, Vol VI, No. 4, Zeus Development Corporation, (Houston, TX, Fourth Quarter 1996).

- Natural Gas Fuels, RP Publishing, Inc., (Denver, CO, September 1996).

- State Energy Data Report 1995 (DOE/EIA-0214(95)) Energy Information Administration, (Washington, DC, July 1997).

- Transportation Energy Data Book: Edition 16, a published report prepared for the U.S. Department of Energy, Office of Transportation Technologies, by Oak Ridge National Laboratory, (Oak Ridge, TN, July 1996).

- 1996 Transit Vehicle Data Book, American Public Transit Association (Washington, DC, July 1996).

\section{Federal}

The number of Federal AFV's in use or planned to be in use from 1996 to 1998 was estimated as accumulated vehicle acquisitions less retirements. Vehicle acquisitions data were obtained from the U.S. Department of Energy's (DOE's) Office of Energy Efficiency and Renewable Energy. Those data were based largely on Federal agency reports filed in compliance with Executive Order 13031 and reports on purchases or conversions of AFV's from 
the U.S. General Services Administration (GSA). Vehicle acquisition data were adjusted to account for extra credits allotted to dedicated electric, medium- and heavy-duty AFV's by Executive Order 13031. For this report, the credits were converted to represent actual vehicle numbers. Federal vehicle retirements were estimated using information supplied by the Office of Energy Efficiency and Renewable Energy and GSA. The geographic and weight class distributions of Federal AFV's were estimated from information obtained over: the last two years through contacts with the Federal agencies that operate AFV's.

\section{State and Local Government Fleets and Privately Owned AFV's}

Liquefied Petroleum Gas (LPG) Vehicles. The U.S. total of LPG vehicles in use in 1996 was estimated from Statelevel data. For 15 States, LPG vehicles were enumerated from data reported by State energy offices or other reasonably accurate sources. For the remaining States, the numbers of LPG vehicles in use were imputed. To impute the vehicle counts, an estimate of average fuel consumption (gallons of LPG per vehicle) was calculated from the 15 enumerable States using estimates of LPG consumption in onroad transportation engines, as reported in the State Energy Data Report 1995. A State's total LPG consumption was then divided by the implied average consumption per vehicle to estimate the number of LPG vehicles in the State.

It is worth noting that the States for which reasonably accurate vehicle counts can be estimated directly changes from year to year, as different States introduce or discontinue decal programs or annual inspection and registration requirements. The number of enurnerable States has declined by one since last year's report.

It is also important to note that the quality of data on LPG usage as an onroad engine fuel varies from State to State. States with pump-based fuel taxes tend to have more accurate estimates than States with decals in lieu of pumpbased taxes. On the other hand, States with lax or nonexistent annual inspection programs tend to have more misreporting of fuel use regardless of decals or pump-based taxes. The implied usage of fuel per vehicle per year varies widely (by nearly a factor of 10 ) from State to State. Other data on sales of tanks for use in onroad vehicles confirm the inconsistencies (on average) for reported fuel usage and vehicle counts.

Data limitations also create uncertainty in identifying the weight and ownership classifications of LPG vehicles.
Only a few States can supply unambiguous decal counts by weight class. No two States use the same definition of weight classes. States with a strong LPG vehicle infrastructure have much higher percentages of light-duty vehicles than those where LPG is used mostly for nonvehicular applications. Similar variations exist for the ownership by State and local governments and private entities. The estimated fractions used in this report ( 20 percent heavy-duty and 20 percent State and local) are approximate figures drawn from a limited sample of widely divergent State inputs.

Estimates of LPG vehicles expected to be in use in 1997 and 1998 were derived from survey information collected by DOE's Clean Cities program. The survey, conducted in late 1996 and early 1997, collected a variety of information about AFV's and AFV plans from the designated Clean Cities. However, the response was not very complete. The responding Clean Cities anticipated about a three percent increase in the next two years for LPG vehicles.

Although very careful enumeration and imputation generates a fleet count of roughly 263,000 in 1996, the actual count could be as high as 300,000 to 350,000 . The known data limitations, the inconsistencies between tank sales and decal sales, and the widespread acknowledgment of misreporting and under reporting of vehicles and fuels suggest that the values reported in this document are minimum values.

Compressed Natural Gas (CNG) Vehicles. The estimation method for $\mathrm{CNG}$ vehicles in use represented the only major methodological change from earlier Alternatives to Traditional Transportation Fuels reports. For prior reports, private, independent annual surveys of natural gas suppliers and owners of CNG refueling stations provided data on CNG vehicles in use. For this report, however, the number of AFV's made available in 1996 and planned to be made available in 1997, less an estimate of vehicle retirements, was added to the base year 1995 estimate. The AFV Vehicle Suppliers Survey (EIA-886) was the source of data for AFV's made available and planned to be made available. Retirement rates were assumed to be the same as conventional vehicles of the same type. Scrappage and survival rates were obtained from the Transportation Energy Data Book.

The U.S. totals derived in this manner were distributed to ownership and geographic categories by combining information from a number of sources. Those sources included the Clean Cities survey (see LPG section), a survey of natural gas companies conducted by Natural Gas 
Fuels, ${ }^{22}$ State agencies or energy offices, APTA and FTA (for information on transit buses), the Natural Gas Vehicle Coalition (for information on school buses), and various other sources. These sources, particularly the Clean Cities survey, were also used to estimate the number of CNG vehicles expected to be in use in 1998.

Liquefied Natural Gas (LNG) Vehicles. A large portion of the LNG vehicles in use are transit buses. Data for LNG transit buses were obtained from the APTA and FTA publications noted above. Other LNG vehicles were identified from industry literature, such as LNG Express and Natural Gas Fuels, and from contacts with organizations that are actively involved in LNG programs such as the National Renewable Energy Laboratory (NREL). NREL has sponsored and kept data on some LNG demonstration programs.

Alcohol-fueled Vehicles. Vehicle counts for each State were compiled from the Clean Cities survey, transit bus data, State energy offices, and alcohol vehicle associations (ethanol only), vehicle demonstration programs, and manufacturers and converters of vehicles and engines.

Almost all the methanol vehicles in use currently are OEM vehicles operated in California. Data for annual acquisitions of light-duty, OEM, methanol vehicles in California were obtained from the California Energy Commission (CEC). CEC data are based on vehicle sales by model year. These data were adjusted for retirements using conventional vehicle retirement rates. Counts of lightduty methanol-fueled vehicles for all other States were derived from State energy office contacts and/or Clean Cities data. Heavy-duty methanol vehicles are predominantly school buses. Data on methanol school buses was obtained from the California Energy Commission and other sources.

Heavy-duty ethanol vehicles were identified individually from transit bus data or from AFDC demonstration programs. Light-duty ethanol vehicles in use were estimated from State contacts and the Clean Cities survey: The numbers of ethanol vehicles in use were adjusted, where necessary, to reflect new vehicles made available and information from the Ethanol Vehicle Coalition.

Electric Vehicles. The numbers of light-duty electric vehicles in use was estimated from telephone contacts with State offices, the Clean Cities survey and database, and industry literature. They were adjusted, where appropriate, to reflect new vehicles made available. Data on electric transit buses was obtained from APTA and FTA. Electric school buses were identified from information provided by the CEC, the Electric Transit Vehicle Institute, and industry literature.

Some degree of uncertainty is associated with electric vehicle estimates because of differences in the definitions of an onroad electric vehicle. To eliminate some of this uncertainty, the definition of electric vehicles has been restricted for this report. For example, prototypes, large golf carts, school-based kit vehicles, unconfirmed hobbyist vehicles, and nonhighway vehicles were excluded from the electric vehicle definition.

\section{Alternative Transportation Fuel Consumption}

Alternative transportation fuel (ATF) consumption was calculated using the following steps:

\section{Alternative-Fueled Vehicles Categorization}

Alternative-fueled vehicles in a given year were categorized according to fuel type; vehicle type (auto, lightduty truck, heavy-duty truck, school bus, or transit bus), and; ownership (private, State and local government, or Federal government). Light-duty vehicles were segmented further into three broad fleet types: rental and service vehicles; private passenger and carpool vehicles; and government pool vehicles. Heavy-duty trucks, as defined by EPACT, were segmented into medium- and heavy-duty categories.

\section{Vehicle Miles Traveled (VMT) by Alternative-Fueled Vehicle Classification and Fleet Type}

The annual average VMT values for conventional fleets were assigned to each vehicle classification. The conventional fleet characteristics used in the estimation process are listed in Table A1. The annual VMT values of conventional vehicles shown in Table A1 were revised downward to reflect the less intensive use of AFV's when compared to conventional vehicles. Factors that reduce AFV utilization relative to conventional vehicles include the following:

- More frequent refueling because of lower heat content of alternative fuels

\footnotetext{
22 "Natural Gas Vehicle Programs of the Top 150 North American Utility Companies," Natural Gas Fuels, RP Publishing, Inc. (Denver, CO, September 1996), p. 24.
} 
Table A1. Typical Conventional Vehicle Characteristics

\begin{tabular}{|c|c|c|c|}
\hline Automobile/Private Rental and Service $\ldots \ldots \ldots \ldots$ & $0-8,500$ & 24,600 & 24 \\
\hline Automobile/Passenger Vehicles and Car Pools ... & $0-8,500$ & 12,000 & 24 \\
\hline Automobile/Government Pool . . . . . . . . . . . . . & $0-8,500$ & 8,000 & 24 \\
\hline Light-Duty Truck $\ldots \ldots \ldots \ldots \ldots \ldots \ldots \ldots$ & $0-8,500$ & 16,400 & 16 \\
\hline Heavy-Duty Truck $\ldots \ldots \ldots \ldots \ldots \ldots \ldots \ldots$ & $14,001-26,000$ & 16,400 & 6 \\
\hline 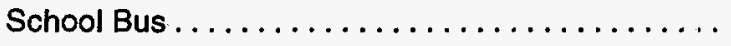 & All & 8,000 & 8 \\
\hline Transit Bus $\ldots \ldots \ldots \ldots \ldots \ldots \ldots \ldots \ldots$ & All & 33,200 & 4 \\
\hline
\end{tabular}

Source: Science Applications International Corporation, "Alternative Transportation Fuels and Vehicles Data Development," unpublished final report prepared for the Energy Iriformation Administration (McLean, VA, July 1996).

- Range restrictions because of limited fuel availability

- Higher maintenance needs and increased incidence of mechanical failures

- Operator perceptions (when choice is available, fleet and vehicle operators may drive conventional vehicles more often than AFV's because of their perceptions of safety, cost, environmental impact, vehicle performance, and refueling ease, regardless of whether these perceptions are correct).

Conventional VMT estimates for transit buses and other heavy-duty AFV's were replaced by VMT estimates for AFV's, where appropriate. Transit bus data were obtained from the Federal Transit Administration's 1995 National Transit Database. Estimates derived from the report Describing Current and Potential Markets for Alternative-Fuel Vehicles ${ }^{23}$ were used to adjust VMT's of LPG and CNG vehicles, where applicable. Also, the AFDC's database was used to adjust VMT's for heavyduty ethanol vehicles.

\section{Adjustments for Bi-, Dual-, and Flexible- Fuel Vehicles}

Vehicles were classified according to whether they were dedicated vehicles (fueled exclusively by replacement fuels) or non-dedicated (bi-, dual-, and flexible-fuel AFV's which consume proportions of alternative and traditional fuels). To obtain the net amount of alternative fuel used by non-dedicated vehicles, their VMT values were divided by their adjusted consumption proportions of alternative versus traditional fuels. These proportions are a function of the following:

- Replacement Fuel Availability: The percentage of traditional fuel used because no replacement fuel is available at the time of refueling.

- Operator's Fuel Choice: The percentage use of replacement fuel that results from the vehicle operator's fuel choice when available. Choice is affected by perceptions of safety, cost, environmental impact, vehicle performance and refueling ease, and by familiarity with the fuel.

\section{Alternative Fuel Efficiencies in Miles per Gallon (mpg)}

The efficiencies in miles per gallon of gasoline were determined for all vehicle categories. Those efficiencies were then converted to mpg of alternative fuel in native units. The native units used are gallons (M85, M100, E85, E95, LPG, and LNG), therms (CNG), and kWh (electricity). For some heavy-duty vehicles, gasoline efficiencies were replaced by native unit efficiencies from the sources described in Step 2.

For several AFV types, the effective total fuel cycle of ATF consumption per miles of travel is higher than commonly thought. Consumption of ATF's is almost always estimated by assuming that Btu equivalent amounts of ATF and traditional fuel produce the same VMT. This assumption is not strictly accurate because of venting of fuel vapor during refueling and maintenance, leakage of

${ }^{23}$ Energy Information Administration, Describing Current and Potential Markets for Alternative-Fueled Vehicles, DOE/EIA-0604 (Washington, DC, March 1996). 
gaseous fuels from fuel lines and storage cylinders, engine efficiency differences, and vehicle weight differences. Although natural gas utilities, transit bus facilities, fleet owners, and-related industry members are not generally able to isolate and quantify these factors, the net effect is lower miles per Btu for most AFV's than for conventional vehicles. The mpg values were adjusted to account for higher effective fuel consumption for LNG-, CNG- and electric vehicles. For these AFV's, the miles per Btu ratio was lowered by decreasing the nominal heating values per native unit of fuel (Table A2).

Table A2. Original and Adjusted Lower Heating Values of Conventional and Replacement Fuels (Thousand Btu per Native Unit of Fuel)

\begin{tabular}{|c|c|c|c|}
\hline Fuel Type & $\begin{array}{c}\text { Original Heating Value } \\
\text { per Native Unit of Fuel }{ }^{\text {a }} \\
\text { (thousand Btu) }\end{array}$ & $\begin{array}{c}\text { Added Fuel Loss } \\
\text { (percent) }\end{array}$ & $\begin{array}{c}\text { Adjusted Heating Value } \\
\text { per Native Unit of Fuel } \\
\text { (thousand Btu) }\end{array}$ \\
\hline Methanol $\ldots \ldots \ldots \ldots \ldots \ldots \ldots \ldots$ & $57.00 /$ Gallon & 0.01 & 57.00/Gallon \\
\hline Ethanol........................ & $76.00 /$ Gallon & 0.01 & 76.00/Gallon \\
\hline Liquefied Petroleum Gases (LPG) ..... & $84.00 /$ Gallon & 0.00 & 84.00/Gallon \\
\hline Compressed Natural Gas (CNG) & 93.00/Therm & 0.50 & 92.54/Therm \\
\hline Electricity & $3.41 / \mathrm{kWh}$ & 2.00 & $3.34 / \mathrm{kWh}$ \\
\hline Liquefied Natural Gas (LNG) & 68.00/Gallon & 2.00 & 66.64/Gallon \\
\hline Diesel ............... & 128.00/Gallon & 0.00 & 128.00/Gallon \\
\hline Gasoline ..................... & 115.00/Gallon & 0.00 & 115.00/Gallon \\
\hline
\end{tabular}

a Lower heating value.

Source: Science Applications International Corporation, emissions model prepared for the Energy Information Administration, (McLean, VA, updated 1994).

\section{Conversion to Replacement and Alternative-Fueled Consumption in Native Units}

The net adjusted annual VMT for alternative-fueled vehicles were then divided by miles per unit of alternative fuel. The result was alternative-fueled consumption by AFV's.

\section{Conversion to Gasoline-Equivalent Gallons}

Fuel consumption in terms of gasoline-equivalent gallons was computed by dividing the adjusted lower heating value of the alternative fuel (thousands of Btu per native unit of fuel) by the lower heating value of gasoline and multiplying this result by the alternative-fueled consumption value (from step 5.)

\section{Oxygenate Consumption}

The consumption of ethanol and MTBE from 1992 through the first quarter of 1997 was estimated from production, net imports, and stock change data obtained from Petroleum Supply Monthly (DOE/EIA-0109). Petroleum Supply Monthly compiles data from the Monthly Petroleum Supply Reporting System, a series of surveys that collect data from refiners, importers, and transporters of crude oil and petroleum products. Oxygenate data are also collected on the Form EIA-819M, "Monthly Oxygenate Telephone Report." Oxygenate consumption is calculated as production plus net imports less stock change. For the remainder of 1997 and for 1998, consumption is derived from unpublished data prepared in support of the Short Term Energy Outlook, Third Quarter 1997, DOE/EIA-0202 (97/3Q).

\section{Form EIA-886 Survey}

\section{Background}

The EIA-886 survey was implemented in 1995 to collect information about alternative-fueled vehicles (AFV's) made available. Section 503(b)(2) of the Energy Policy Act of 1992 (EPACT) requires that the suppliers of AFV's annually report to the DOE the number, type and geographic distribution of AFV's that each supplier "made available" in the previous calendar year and plans to "make available" in the following calendar year. Data provided is destined for use in the United States (including the 50 states and the District of Columbia). A primary goal of the EPACT is to encourage the transportation sector of the United States to increase its use of domestically produced alternative transportation fuels in order to reduce the importing of petroleum. 


\section{Collection Methods}

Survey data are collected annually to satisfy public requests for information on AFV's and to provide Congress with a measure of the extent to which the objectives of the EPACT are being achieved. It is mandatory for each respondent to submit completed forms to EIA within the specified time allotted. The Form EIA-886 must be submitted no later than 30 caleridar days after initial mailout. Telephone follow-up calls to nonrespondents begin the day after the established due date in order to collect all outstanding data. Late submissions and resubmissions are processed when received.

\section{Data Processing}

As the EIA-886 forms are received, they are logged into a Survey Control File (FOXPRO data entry), which maintains status information for each responclent. The data are reviewed manually and then entered into the computer files. They are then processed through an edit program which detects missing data, inconsistencies, outlying values that affect published estimates, and data significantly different from previous data reported by the company. Data that fail the edits are resolved through telephone calls to the data reporters, and corrections and verifications are entered onto the computer files. Statistical reports, including publication tables, are then generated using only acceptable and verified data.

\section{Respondent Frame}

To identify the appropriate respondents, the EIA complied lists of OEM's and converters after researching many types of sources (i.e., trade groups that represent vehicle manufacturers and operators, organizations that promote alternative-fueled vehicles, public documents, institutions that train vehicle converters, etc.) The set of respondents is intended to include all suppliers of AFV's.

\section{Reliability of Data}

Nonsampling errors can be attributed to (1) inability to obtain complete information from all respondents in the survey (i.e., nonresponse); (2) new respondents-those that participated in the current survey year only; (3) nonrespondents-those that were identified in previous surveys who did not respond; (4) response errors; (5) definitional difficulties; (6) mistakes in coding and recording data obtained, and (7) out-of-scope respondents-those that were identified as not supplying alternative-fueled vehicles.

Precautionary steps were taken in all phases of the frame development and data collection, processing, and tabulation process, in an effort to minimize nonsampling errors. In addition, the close cooperative consultation between EIA and the survey respondents and data users result in a more accurate information gathering and reporting process.

\section{Nondisclosure}

The data contained in this publication are subject to statistical nondisclosure procedures. The objective of the disclosure-avoidance procedures, as stated in the EIA Standard 88-05-06, Subject: "Nondisclosure of Company Identifiable Data in Aggregate Cells," is to ensure that confidential, company-identified data are not disclosed in tables where company specific responses may be proprietary and prohibited from public disclosure by 18 U.S.C. 1905. Statistics representing data aggregated from fewer than three companies or that are dominated by input from one or two companies are withheld. EIA identifies cells that are sensitive according to these criteria by applying a statistical formula to the data contained in each cell to determine if a few companies "dominate" the cell. If a cell is sensitive, the data in that cell are suppressed and a " $\mathrm{W}$ " is placed in the publication cell. Also, since many tables include rows or columns totals, some nonsensitive data cells have been suppressed to prevent the reader from calculating the suppressed numbers by simply subtracting the published numbers from the total. 
Appendix B

\section{U.S. Census} Region Map 



\section{Appendix B}

\section{U.S. Census Region Map}

Figure B1. U.S. Census Region Map
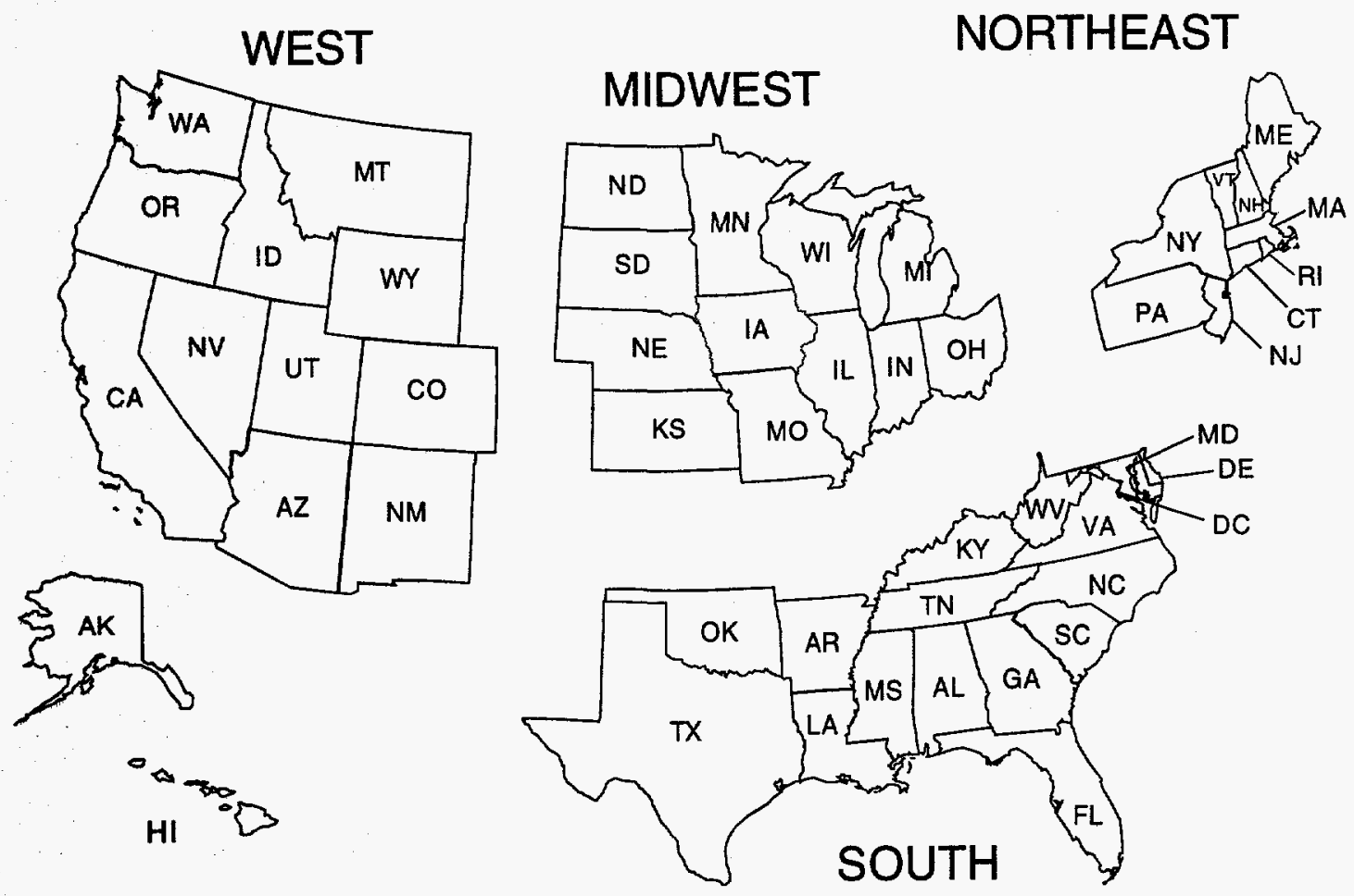

Source: U.S. Department of Commerce, Bureau of the Census 

Appendix C

Alternative-Fueled Vehicle Suppliers 


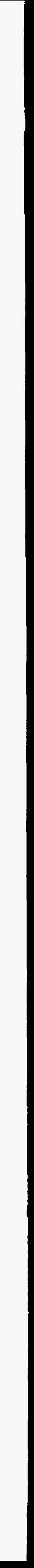


Table C1. Alternative-Fueled Vehicle Suppliers

\begin{tabular}{|c|c|c|c|c|c|}
\hline State and Company Name & Clty & Contact & Phone & Operation Type & $\begin{array}{c}\text { Vehicle Fuel } \\
\text { Type }\end{array}$ \\
\hline \multicolumn{6}{|l|}{ ALABAMA } \\
\hline Diesel Equipment/Auto Air & Birmingham & Pat McKim & (205) 251-4384 & CONVERTER & $\mathrm{HD} / \mathrm{ALCOHOL}$ \\
\hline O'Gwynn, Inc. & Montgomery & Benny J. McDaniel & (334) $264-2243$ & CONVERTER & HD/ ALCOHOL \\
\hline Precision Sales \& Service, Inc & Birmingham & Buddy Gamel & (205) 591-2266 & CONVERTER & $\mathrm{HD} / \mathrm{CNG}$ \\
\hline \multicolumn{6}{|l|}{ ARKANSAS } \\
\hline AZ Technologies, Inc. & Hardy & Les Adam & (501) 856-3732 & OEM & LD/ ALCOHOL \\
\hline Cabot Propane Co., Inc. & Cabot & Tommy Coates & (501) 843-1217 & CONVERTER & HD/ FLEX \\
\hline Fricks Butane Gas & Texarkana & Clay Fricks & (501) $774-5892$ & CONVERTER & HD/CNG \\
\hline Matthews Propane Gas Co. & Dumas & James Matthews & (501) $382-4353$ & CONVERTER & $\mathrm{HD} / \mathrm{CNG}$ \\
\hline Southem LP Gas & DeQueen & Ray Still & (501) 642-2234 & CONVERTER & HD/ FLEX \\
\hline \multicolumn{6}{|l|}{ ARIZONA } \\
\hline$A M F A B$ & Phoenix & Phil Terry & (602) 243-5833 & CONVERTER & HD/ELECTRIC \\
\hline $\begin{array}{l}\text { Gas Development Resources, } \\
\text { Inc. }\end{array}$ & Phoenix & J.C. O'Connor & (602) $861-3040$ & CONVERTER & $\mathrm{MD} / \mathrm{CNG}$ \\
\hline Naumann Hobbs & Phoenix & Ken Settle & (602) $437-1331$ & CONVERTER & HD/ ALCOHOL \\
\hline North American Fleet Services & Phoenix & Nathan Learner & (602) 254-4366 & CONVERTER & HD/ ALCOHOL \\
\hline \multicolumn{6}{|l|}{ BRITISH COLUMBIA } \\
\hline Ballard Power Systems & Bumaby & Paul Lancaster & (604) 454-0900 & & MD/ELECTRIC \\
\hline Canadian Electric Vehicles Ltd & Lantzville & Randy Holmquest & (250) $390-3364$ & CONVERTER & HD/CNG \\
\hline Zutter Electric Vehicles & Bowen Island & Daniel Zutter & (604) 947-0798 & OEM & HD/LNG \\
\hline \multicolumn{6}{|l|}{ CALIFORNIA } \\
\hline A-1 Auto Electric & Fresno & Mark Gillo & (209) 485-4427 & CONVERTER & LD/ ALCOHOL \\
\hline A-Z Bus Sales, Inc. & Colton & Judy Rieke & (909) $781-7188$ & DEALER/OTHER & ALCOHOL \\
\hline AC Propulsion, Inc. & San Dimas & Tom Gage & (909) 592-5399 & OEM & $\mathrm{MD} / \mathrm{CNG}$ \\
\hline APS Systems & Oxnard & Ed Atelian & (805) 984-0300 & OEM & MD/CNG \\
\hline Allied Propane Service, Inc. & Richmond & Philip Teaderman & (510) 237-7077 & CONVERTER & HD/CNG \\
\hline Alternate Fuel Technologies, Inc. & $\begin{array}{l}\text { Huntington } \\
\text { Beach }\end{array}$ & Bruce Eikelberger & (714) $842-3017$ & CONVERTER & LD CNG \\
\hline $\begin{array}{l}\text { American Gas \& Tech. } N . S \text {. } \\
\text { NGVs }\end{array}$ & San Jose & Ray Tate & (408) 292-6487 & CONVERTER & LD/2CNG \\
\hline American Honda Motor Co., Inc. & Torrance & Steve Ellis & (310) $783-3987$ & OEM & HD/ALCOHOL \\
\hline Big H Inc & El Cajon & Howard Hawkins & (619) $449-6263$ & CONVERTER & HD/CNG \\
\hline Bus Manufacturing USA & MicClellan AFB & Robert Davis & (916) 925-6680 & OEM & MD/LPG \\
\hline
\end{tabular}


Table C1. Alternative-Fueled Vehicle Suppliers (Continued)

\begin{tabular}{|c|c|c|c|c|c|}
\hline State and Company Name & City & Contact & Phone & Operation Type & $\begin{array}{c}\text { Vehicle Fuel } \\
\text { Type }\end{array}$ \\
\hline CE-CERT & Riverside & Mitch Boretz & (909) $781-5785$ & & \\
\hline California Electric Auto. Co. & Lakeside & Ronald Larrea & (619) $443-3017$ & CONVERTER & MD/CNG \\
\hline California Electric Cars, Inc. & Seaside & Thomas Brooks & (408) $899-2012$ & OEM & HD/.NG \\
\hline Envirotech Equipment Company & Valencia & Toni Lennon & (818) 373-0285 & CONVERTER & HD/OTHER \\
\hline Eyeball Engineering & Riverside & Eric Luebben & (909) 682-8686 & CONVERTER & HD/L.NG \\
\hline Gillig Corporation & Hayward & Charles Koske & (510) $785-1500$ & OEM & LD/ALCOHOL \\
\hline Goremotive Industries, Inc. & Tarzana & Arthur Sweet & (818) $757-7072$ & & CNG \\
\hline Mike's Autocare & San Mateo & Mike Slominski & (415) $343-8801$ & CONVERTER & $\mathrm{HD} / \mathrm{CNG}$ \\
\hline Mutual Liquid Gas \& Equip. Co. & Gardena & M. Steven Moore & (310) 515-0553 & CONVERTER & HD/CNG \\
\hline National Auto Center & Rancho Cordova & Rick Yakesh & (916) $985-3618$ & CONVERTER & LD/CNG \\
\hline Power System Associates, LLC & Los Angeles & Kevin Campbell & (310) 463-6033 & OEM & LD/ALCOHOL \\
\hline Pro Electric Vehicles & Penn Valley & Craig McCann & (916) $432-5244$ & CONVERTER & HD/CNG \\
\hline SW Div. Naval Facilities Eng. & San Diego & Chau Vu & (619) $532-3974$ & CONVERTER & HD/ALCOHOL \\
\hline SWAN Group & Burbank & Bob Rintz & (818) 565-5505 & DEALER/OTHER & LNG \\
\hline San Francisco St. Univ. Trans. & San Francisco & Patricia Tolar & (415) 338-2744 & OEM & \\
\hline Valley Detroit Diesel Allison & Mira Loma & Chuck Milam & (909) $681-9283$ & CONVERTER & ELECTRIC \\
\hline Volt Age, Inc. & Gardena & Robert Hadden & (310) $532-4536$ & CONVERTER & $\mathrm{HD} / \mathrm{CNG}$ \\
\hline Western Propane Service & Santa Maria & Steve Brown & (805) $922-8017$ & CONVERTER & HD/FLEX \\
\hline Zap Power Systems & Sebastopol & Alex Campbell & (707) $824-4150$ & CONVERTER & CNG \\
\hline \multicolumn{6}{|l|}{ COLORADO } \\
\hline Glaser Gas, Inc. & Calhan & Dave Glaser & (719) 596-4765 & CONVERTER & HD/FLEX \\
\hline J-W Operating Company & Wray & Andrew R. Weaver & (970) $332-3151$. & CONVERTER & HD/ALCOHOL \\
\hline Kaylor Energy Products & Boulder Creek & Ron Kaylor & (408) 338-2200 & OEM & HD/LNG \\
\hline Natural Fuels Corp. & Denver & Paul Nelson & (303) $322-4600$ & CONVERTER & HD/ALCOHOL \\
\hline Neoplan USA Corporation & Lamar & Joyce Surprise & (719) $336-3256$ & OEM/OTHER & ALCOHOL \\
\hline Quality Propane Thermogas & Denver & Charley Breternitz & (303) 287-9700 & CONVERTER & HD/FLEX \\
\hline Unique Mobility, Inc. & Golden & Kevin Barnes & (303) 278-2002 & CONVERTER & MD/ELECTRIC \\
\hline
\end{tabular}


Table C1. Alternative-Fueled Vehicle Suppliers (Continued)

\begin{tabular}{|c|c|c|c|c|c|}
\hline State and Company Name & City & Contact & Phone & Operation Type & $\begin{array}{c}\text { Vehicle Fuel } \\
\text { Type }\end{array}$ \\
\hline \multicolumn{6}{|l|}{ CONNECTICUT } \\
\hline Capuano GMC & Torrington & Roger Hackbarth & (860) $496-2323$ & CONVERTER & HD/ALCOHOL \\
\hline Grasmere Sunoco & Fairtield & Jerry Kozera & (203) 255-0328 & CONVERTER & HD/FLEX \\
\hline \multicolumn{6}{|l|}{ DISTRICT OF COLUMBIA } \\
\hline Nissan North America & Washington & Michinori Hachiya & (202) $466-5284$ & OEM & HD/LNG \\
\hline \multicolumn{6}{|l|}{ FLORIDA } \\
\hline EVRIDER & Sarasota & Larry Meadows & (941) $351-6443$ & OEM & LNG \\
\hline Live Oak Gas Co., Inc. & Live Oak & David Chandler & (904) 362-2424 & CONVERTER & HD/CNG \\
\hline Motor Fuelers, Inc. & Clearwater & Barry J. Tilmann & (813) $572-9762$ & CONVERTER & $\mathrm{HD} / \mathrm{CNG}$ \\
\hline OCLI, Inc. & Miami & Ken Green & (305) 651-2220 & CONVERTER & $\mathrm{LD} / \mathrm{CNG}$ \\
\hline Palm Beach County Fleet Mgmt. & $\begin{array}{l}\text { West Palm } \\
\text { Beach }\end{array}$ & Doug Weichman & (561) 233-4550 & CONVERTER & HD/ALCOHOL \\
\hline Pinellas Suncoast Transit Co. & Cleanwater & Michael J. Siebel & (813) 530-9921 & & \\
\hline Sarasota Cty Sheriffs Office & Osprey & Steven W Meadows & (941) $486-2363$ & CONVERTER & HD/FLEX \\
\hline Suburban Propane LP SE Carb. & Sarasota & Wayne Moore & (941) $755-3761$ & CONVERTER & HD/FLEX \\
\hline Electronic Fuel Control, Inc. & Forest Park & Jeffrey Davis & (404) $765-0131$ & CONVERTER & LD/CNG \\
\hline REVI & Alpharetta & David Lowe & $(770) 664-6559$ & OEM & LNG \\
\hline \multicolumn{6}{|l|}{ HAWAII } \\
\hline The Gas Company & Honolulu & Brad Saito & (808) 594-5584 & CONVERTER & HD/CNG \\
\hline \multicolumn{6}{|l|}{ IOWA } \\
\hline Fosseen Mfg \& Development, Ltd. & Radcliffe & Dwayne Fosseen & (515) $899-2115$ & CONVERTER & $\mathrm{MD} / \mathrm{CNG}$ \\
\hline MidAmerican Energy Company & Sioux City & Douglas Burkett & (712) $277-7738$ & CONVERTER & $\mathrm{HD} / \mathrm{ALCOHOL}$ \\
\hline Siouxland Propane & Ireton & Greg Vreeman & (712) $278-2362$ & CONVERTER & HD/FLEX \\
\hline \multicolumn{6}{|l|}{ IDAHO } \\
\hline LMITCO Lockheed ID Tech. Co. & Idaho Falls & Kevin B. Brown & (208) 526-2075 & CONVERTER & LD/ALCOHOL \\
\hline \multicolumn{6}{|l|}{ ILLINOIS } \\
\hline Cady Oil Co. & Peoria Heights & Steven T. Cady & (309) 688-1264 & CONVERTER & $\mathrm{HD} / \mathrm{ALCOHOL}$ \\
\hline
\end{tabular}


Table C1. Alternative-Fueled Vehicle Suppliers (Continued)

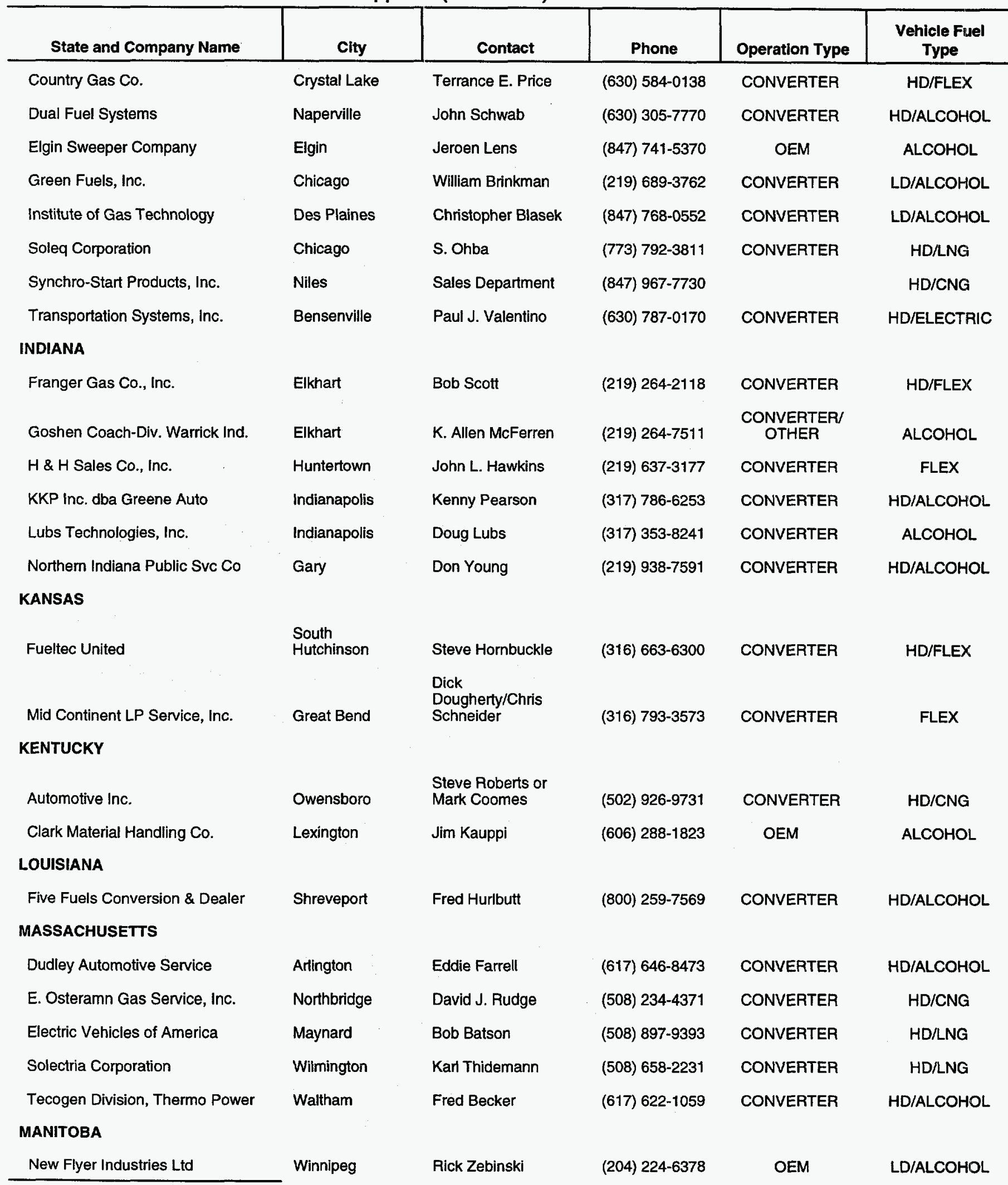

See notes at end of table. 
Table C1. Alternative-Fueled Vehicle Suppliers (Continued)

\begin{tabular}{|c|c|c|c|c|c|}
\hline State and Company Name & City & Contact & Phone & Operation Type & $\begin{array}{l}\text { Vehicle Fuel } \\
\text { Type }\end{array}$ \\
\hline \multicolumn{6}{|l|}{ MARYLAND } \\
\hline Atlantic Transportation Equip. & Beltsville & Tom Niswander & (301) 210-5100 & DEALER & $\mathrm{LD} / \mathrm{ALCOHOL}$ \\
\hline Baltimore Gas \& Electric Co. & Baltimore & $\begin{array}{l}\text { Leslie Stephenson, } \\
\text { Sr }\end{array}$ & (410) 597-7601 & CONVERTER & $\mathrm{HD} / \mathrm{ALCOHOL}$ \\
\hline \multicolumn{6}{|l|}{ MICHIGAN } \\
\hline Advanced Fuel Tech., Inc. & Midland & Gary Shepherd & (517) $835-8613$ & CONVERTER & $\mathrm{HD} / \mathrm{CNG}$ \\
\hline Beacon Power Systems, Inc. & Troy & Joann Blakenship & $810-589-7888$ & CONVERTER & $\mathrm{HD} / \mathrm{ALCOHOL}$ \\
\hline Chrysler Corporation & Auburn Hills & Fred Maloney & $(810) 576-5472$ & OEM BUSES & ALCOHOL \\
\hline Ford Motor Company & Dearborn & $\begin{array}{l}\text { Hotline, AFV Product } \\
\text { Line }\end{array}$ & $\begin{array}{l}(800) \\
\text { ALT-FUEL }\end{array}$ & OEM BUSES & ALCOHOL \\
\hline General Coach America & Brown City & Brad Buchanan & $(810) 346-3485$ & OEM/OTHER & ALCOHOL \\
\hline General Motors Corporation & Detroit & Dr. Gerald J. Barnes & (313) $556-7723$ & OEM & HD/ALCOHOL \\
\hline MSX intemational & Detroit & Ford EV Division & (313) $922-0050$ & CONVERTER & HD/FLEX \\
\hline Modern Engineering & Dearborn & Robert Childs & (313) $317-9675$ & CONVERTER & HD/FLEX \\
\hline Northwest Propane, Inc. & Holly & Bruce Barget & $(810) 666-2111$ & CONVERTER & HD/FLEX \\
\hline Southeastern Michigan Gas Co. & Port Huron & Charles F. Lambert & $(810) 987-7900$ & CONVERTER & HD/ALCOHOL \\
\hline Spartan Motors & Charlotte & John Gaedert & (517) $543-6400$ & CONVERTER & \\
\hline Starghill Alternative Energy & Detroit & Walter Starghill, Sr. & (313) $933-4141$ & CONVERTER & LD/LPG \\
\hline Thermal Power Corporation & Sterling Heights & Mark Corlee & (810) 264-1200 & & LD/LPG \\
\hline Trans 2 Corportation & Livonia & James M. Thomas & (313) $513-2800$ & OEM & LNG \\
\hline Volkswagen of America, Inc. & Auburn Hills & Stuart Johnson & (810) $340-4708$ & OEM BUSES & ALCOHOL \\
\hline \multicolumn{6}{|l|}{ MINNESOTA } \\
\hline Acme Alternate Fuel Systems, Inc. & Mankato & Dale Hudson & (507) $345-4000$ & CONVERTER & $\mathrm{HD} / \mathrm{CNG}$ \\
\hline Carburetion \& Turbo Systems & Shakopee & David Leivestad & (612) $445-3910$ & CONVERTER & LD/CNG \\
\hline Circle Pines Utilities & Circle Pines & James Keinath & (612) 784-5898 & & \\
\hline Minnegasco, A Norman Energy Co. & Minneapolis & Steve Graning & $(612) 861-8697$ & CONVERTER & HD/ALCOHOL \\
\hline Propane Gas Products & Minneapolis & Hartley Medin & (612) 529-9276 & CONVERTER & HD/FLEX \\
\hline \multicolumn{6}{|l|}{ MISSOURI } \\
\hline All Star Gas (field services) & Lebanon & Bob Schall & $(417) 532-3103$ & CONVERTER & HD/FLEX \\
\hline Coots Carburetion \& Service Ctr. & Lathrop & Harold Coots & (816) 528-4505 & CONVERTER & HD/FLEX \\
\hline GASCO & Eldon & Ed Simmons & (573) $392-4275$ & CONVERTER & HD/CNG \\
\hline Tiger Tractor Corporation, The & Lee's Summit & Doug Falky & (816) $525-3900$ & OEM & FLEX \\
\hline \multicolumn{6}{|l|}{ MISSISSIPPI } \\
\hline Graeber Brothers, Inc. & Clarksdale & Skip Graeber & $(601) 624-4326$ & CONVERTER & HD/FLEX \\
\hline
\end{tabular}


Table C1. Alternative-Fueled Vehicle Suppliers (Continued)

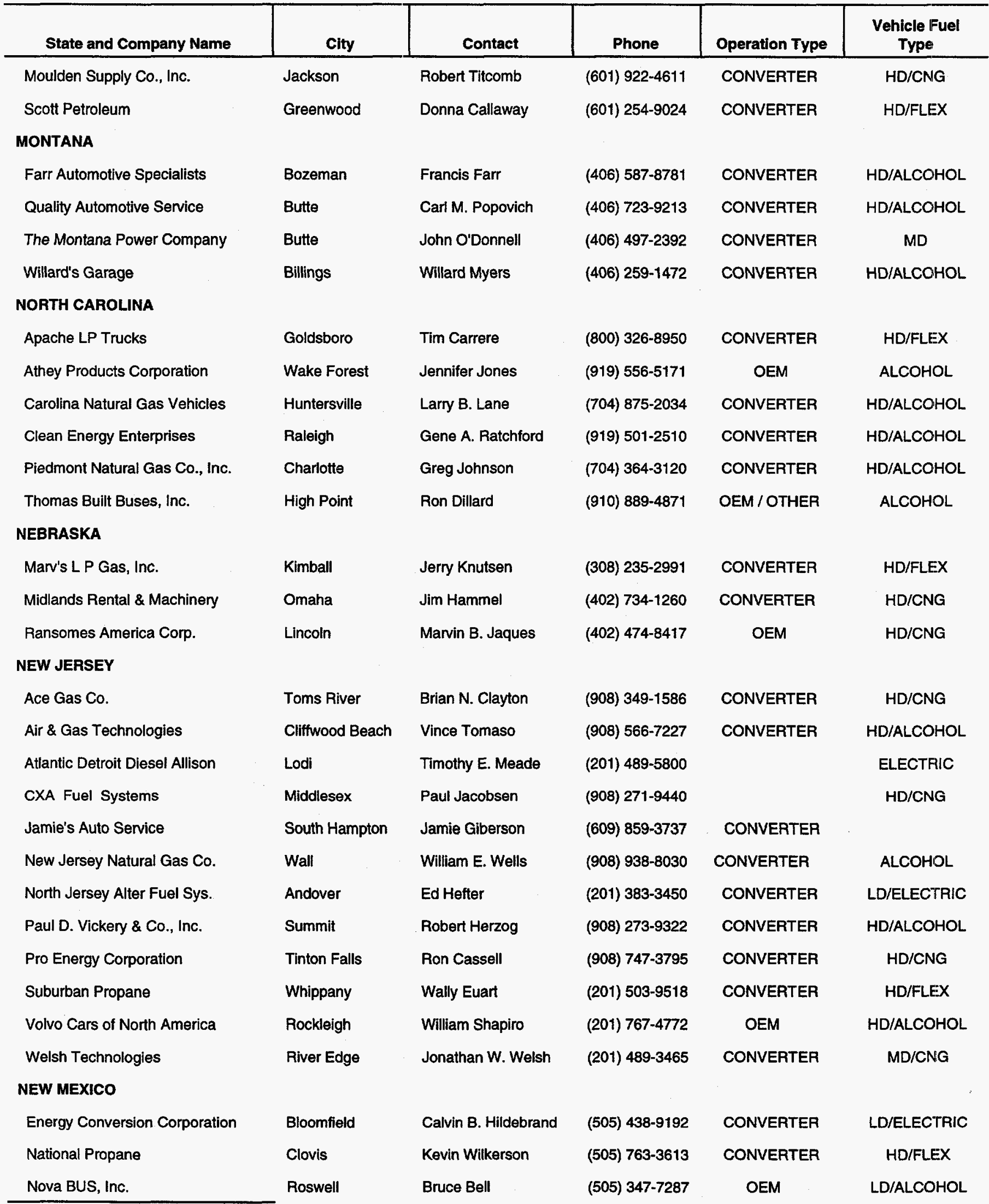

See notes at end of table. 
Table C1. Alternative-Fueled Vehicle Suppliers (Continued)

\begin{tabular}{|c|c|c|c|c|c|}
\hline State and Company Name & City & Contact & Phone & Operation Type & $\begin{array}{l}\text { Vehicle Fuel } \\
\text { Type }\end{array}$ \\
\hline Pub. Srvc. Co. of New Mexico & Albuquerque & Doug Taylor & (505) $241-4401$ & CONVERTER & HD/ALCOHOL \\
\hline Rust Tractor Company & Albuquerque & Don Balestrieri & (505) $345-8411$ & CONVERTER & FLEX \\
\hline Stewart \& Stevenson Power, Inc. & Farmington & Dale Stevens & (505) $325-5017$ & CONVERTER & $\mathrm{HD} / \mathrm{CNG}$ \\
\hline \multicolumn{6}{|l|}{ NEVADA } \\
\hline A-55 Limited Partnership & Reno & Dick Cooper & (702) $826-8300$ & CONVERTER & MD \\
\hline City of Las Vegas & Las Vegas & Dan Hyde & (702) 229-6971 & CONVERTER & HD/ELECTRIC \\
\hline The Car Doctor, Inc. & Las Vegas & Jan Monaghan & (702) $732-0112$ & CONVERTER & $\mathrm{HD} / \mathrm{CNG}$ \\
\hline Yellow, Checker, Star Cab Co. & Las Vegas & Jack Owens & (702) $873-8012$ & CONVERTER & HD/FLEX \\
\hline \multicolumn{6}{|l|}{ NEW YORK } \\
\hline 4 Wheel Driveline Systems & Staten Island & Jay Losey & (718) $447-3038$ & CONVERTER & $\mathrm{HD} / \mathrm{CNG}$ \\
\hline Altemative Fuels Technologies & Jamaica & Michael DiGonis & (718) 529-0300 & CONVERTER & LD/CNG \\
\hline Aurora Technology Corp. & East Aurora & Jose Ruiz & $(716) 655-4681$ & CONVERTER & CNG \\
\hline Command Bus Lines & Brooklyn & Edward Talbot & (718) $272-0900$ & & \\
\hline Electric Launch Company & Highland & C. G. Houghton & (914) 691-3777 & OEM & LPG \\
\hline Empire Associates & Staten Island & Robert Turan & (718) $720-5198$ & CONVERTER & HD/ALCOHOL \\
\hline Glenn's Sales and Service & Shortsville & Glenn Salisbury & (716) $289-4298$ & CONVERTER & HD/ALCOHOL \\
\hline Matthews Buses, Inc. & Ballston Spa & Mike Marlin & (518) 584-2400 & OEM & \\
\hline NYSEG NGV Technology Center & Endicott & Bob Stiles & (607) $762-4019$ & CONVERTER & $\mathrm{HD} / \mathrm{CNG}$ \\
\hline Northeast Energy Equipment & Bellport & Frank Dupointe & (516) 286-5600 & CONVERTER & HD/ALCOHOL \\
\hline Orion Bus Industries, Inc. & Oriskany & John Riet & (315) $768-8101$ & OEM/OTHER & ALCOHOL \\
\hline Thompson \& Johnson Equip. Co. & East Syracuse & $\begin{array}{l}\text { David } \\
\text { Schneckenburger }\end{array}$ & (315) $437-2881$ & CONVERTER & CNG \\
\hline \multicolumn{6}{|l|}{ OHIO } \\
\hline Alternative Fuels Equipment & Cleveland & Les Ashby & (216) $232-4111$ & CONVERTER & HD/ALCOHOL \\
\hline B \& M Compressor Co., Inc. & Cleveland & Timothy R. Boyle & (216) $881-9494$ & & MD \\
\hline Daewoo & Warren Heights & Michael J. Lavelle & (216) 595-1212 & OEM & LNG \\
\hline Elwell-Parker Electric Company & Cleveland & Curtis Roupe & (216) $881-6200$ & OEM & HD/LNG \\
\hline $\begin{array}{l}\text { Greater Cleveland Regional Transit } \\
\text { Authority }\end{array}$ & Cleveland & Ronald J. Tober & (216) $566-5218$ & OTHER & ALCOHOL \\
\hline NESC, Williams, Inc. & Zanesville & Earl Biederman & (216) 662-0225 & CONVERTER & HD/CNG \\
\hline Northwestem College & Lima & Ronald E. Roeder & (419) 998-3160 & CONVERTER & HD/ALCOHOL \\
\hline Thor Industries, Inc. & Jackson Center & Walter Bennett & (937) 596-6849 & OEM/OTHER & ALCOHOL \\
\hline Universal Coach Parts, Inc. & Delaware & Raymond Miles & (614) $362-2607$ & OEM/OTHER & ALCOHOL \\
\hline \multicolumn{6}{|l|}{ OKLAHOMA } \\
\hline Briscoe's LP Gas Service, Inc. & Mustang & Ronnie Blurton & (405) 376-2407 & CONVERTER & HD/FLEX \\
\hline
\end{tabular}


Table C1. Alternative-Fueled Vehicle Suppliers (Continued)

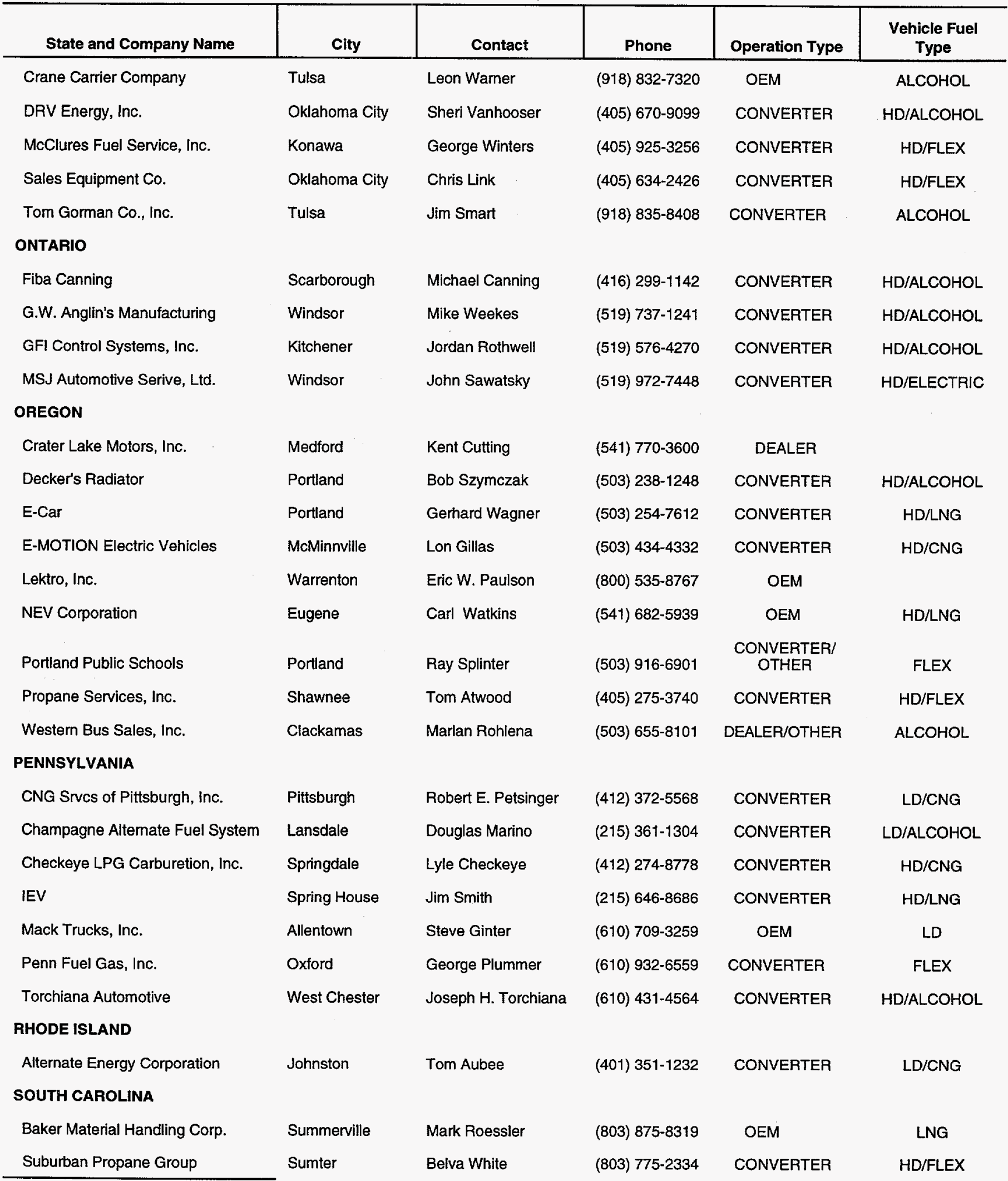

See notes at end of table. 
Table C1. Alternative-Fueled Vehicle Suppliers (Continued)

\begin{tabular}{|c|c|c|c|c|c|}
\hline State and Company Name & City & Contact & Phone & Operation Type & $\begin{array}{c}\text { Vehicle Fuel } \\
\text { Type }\end{array}$ \\
\hline \multicolumn{6}{|l|}{ SOUTH DAKOTA } \\
\hline Gales Gas Service & Pierre & Jack Nafus & (605) 224-5518 & CONVERTER & HD/FLEX \\
\hline Lemmon Propane, Inc. & Lemmon & Ron Dauwen & (605) $374-5412$ & CONVERTER & HD/FLEX \\
\hline Advanced Vehicle Systems, Inc. & Chattanooga & Joe Ferguson & (423) $821-3146$ & OEM/OTHER & LNG \\
\hline Southern Meter Service & Hohenwald & David Riley & (615) $796-3733$ & CONVERTER & $\mathrm{HD} / \mathrm{CNG}$ \\
\hline United Cities Propane Gas & Franklin & Anthony Slayden & (615) 591-6200 & & MD \\
\hline \multicolumn{6}{|l|}{ TEXAS } \\
\hline Alternative Fuel Systems Auto. & Round Rock & Mike Stone & (512) $218-4147$ & & \\
\hline B \& B Fuel Co., Inc. & Seminole & C. R. Bruce & (915) 758-3221 & CONVERTER & HD/FLEX \\
\hline BMS & Pearland & Ronnie Yard & (281) 482-7007 & CONVERTER & HD/FLEX \\
\hline Barbour Brothers, Inc. & Tulia & B. R. Barbour & (806) 995-3366 & CONVERTER & HD/FLEX \\
\hline Benson Repair Service, Inc. & Sonora & Frederick C. Benson & (915) $387-2966$ & CONVERTER & HD/ALCOHOL \\
\hline Birdsong Automotive & Beaumont & Tracy Birdsong & (409) 842-2822 & CONVERTER & HD/ELECTRIC \\
\hline Boyd's Equipment, Inc. & Amarillo & Gordon Gabert & (806) $372-5981$ & CONVERTER & HD/FLEX \\
\hline C. Clark Propane, Inc. & Pampa & Mark Clark & (806) 665-4018 & CONVERTER & HD/FLEX \\
\hline ExproFuels & San Antonio & Frank Alderman & (800) 831-9532 & CONVERTER & HD/ALCOHOL \\
\hline Fletcher Service Co. & Eagle Pass & Douglas J. Fletcher & (210) $773-2816$ & CONVERTER & HD/CNG \\
\hline Frank's Fuels, Inc. & Odessa & Charlie Stubbs & (915) 332-0829 & CONVERTER & HD/FLEX \\
\hline Green's Blue Flame Gas Co., Inc. & Houston & Joe Green & (713) $462-5414$ & CONVERTER & HD/CNG \\
\hline Haigood \& Campbell & Archer City & Ward Campbell & (817) $574-2521$ & CONVERTER & HD/FLEX \\
\hline Hall Propane Co. & Port Lavaca & Sharon Hall & (512) 552-5587 & CONVERTER & FLEX \\
\hline Hino Gas & Harlingen & Yolanda Robles & (210) 423-9178 & CONVERTER & LD/LPG \\
\hline Independent Oil Co. dba Dixie & Hillsboro & Lynn B. Gray & (817) 582-5359 & CONVERTER & HD/FLEX \\
\hline J \& L Propane, Inc. & Krum & Raymond Johnson & (817) $482-3225$ & CONVERTER & HD/FLEX \\
\hline J.V. Equipment Co., Inc. & Edinburg & Don Drewry & (210) 383-0777. & CONVERTER & FLEX \\
\hline Kerrville Butane Co. & Ingram & Ricky Jones & (210) 367-5989 & CONVERTER & HD/FLEX \\
\hline M \& M Propane, Inc. & Donna & Troy McMillan & (210) 464-3522 & CONVERTER & $\mathrm{HD} / \mathrm{CNG}$ \\
\hline
\end{tabular}


Table C1. Alternative-Fueled Vehicle Suppliers (Continued)

\begin{tabular}{|c|c|c|c|c|c|}
\hline State and Company Name & City & Contact & Phone & Operation Type & $\begin{array}{c}\text { Vehicle Fuel } \\
\text { Type }\end{array}$ \\
\hline Midtex LP Gas & Midlothian & Flodney Jenkins & (972) $723-3900$ & CONVERTER & HD/FLEX \\
\hline Mission Gas Company & San Antonio & Ted Terry & (210) 633-0721 & CONVERTER & HD/FLEX \\
\hline Nichols LP Gas Service, Inc. & Clifton & Tom Nichols & (817) 675-8001 & CONVERTER & HD/FLEX \\
\hline Peterbilt Motors Company & Denton & Jim Zito & (817) 566-4084 & OEM & LD \\
\hline Petty Butane Co. & Vernon & Scott Inglish & (817) 552-7092 & CONVERTER & HD/FLEX \\
\hline Pinnacle CNG & Midland & Drew Diggins & (915) 686-5989 & CONVERTER & HD/ALCOHOL \\
\hline Propane Systems of Texas, Inc. & Fort Worth & Craig Cartwright & (817) 831-6139 & CONVERTER & HD/FLEX \\
\hline Servigas & El Paso & David Chavez & (915) 833-2961 & CONVERTER & HD/FLEX \\
\hline Southwest Butane Co. & Big Lake & John Daugherty & (915) $884-2185$ & CONVERTER & HD/FLEX \\
\hline ToyotaLift of Houston & Houston & David Novark & (713) 675-7000 & DEALER & \\
\hline TranStar Technologies, L.C. & Dallas & Terry Anglin & (214) $761-0143$ & CONVERTER & LD/ALCOHOL \\
\hline Triangle Corporation & Gainesville & James Gailey & $(817) 665-8341$ & CONVERTER & FLEX \\
\hline Tyler Fuel Injection Service, & Tyler & Iim Florey & (903) 593-3351 & CONVERTER & HD/ALCOHOL \\
\hline Vinyard Engine System, Inc. & San Antonio & Shannon Vinyard & (210) 520-7924 & CONVERTER & LD/ALCOHOL \\
\hline Wallace Envmt. Testing Lab, Inc. & Houston & Les Weaver & (713) 956-7705 & CONVERTER & MD \\
\hline Zeigler LP Systems, Inc. & Livingston & Bob Zeigler & (409) 327-2225 & CONVERTER & HD/CNG \\
\hline \multicolumn{6}{|l|}{ UTAH } \\
\hline Environmental Conversions, Inc. & Ogden & Jerry Williamson & (801) 629-0999 & CONVERTER & HD/LPG \\
\hline Questar Regulated Services & Salt Lake City & Terry Keddington & (801) $324-3673$ & CONVERTER & HD/ALCOHOL \\
\hline Smith Detroit Diesel/Allison & Salt Lake City & Roland Smith & (801) 262-2631 & & HD/ELECTRIC \\
\hline \multicolumn{6}{|l|}{ VIRGINIA } \\
\hline Alternate Fuels Technologies & Woodbridge & Jerry F. Morton & (703) 491-2691 & CONVERTER & HD/CNG \\
\hline Charlotte America & Bluefield & Joe Hart & $(540) 326-1510$ & OEM & LNG \\
\hline Commonwealth Propane, Inc. & Richmond & Byron Roberts & (804) $327-1325$ & CONVERTER & HD/FLEX \\
\hline Enginuity & Virginia Beach & Tom R. Pritchard & (757) $481-7374$ & CONVERTER & $\mathrm{HD} / \mathrm{CNG}$ \\
\hline G\&M Service Center, Inc. & Lorton & Mike Kalcheff & (703) 550-1467 & CONVERTER & LD/CNG \\
\hline
\end{tabular}

See notes at end of table. 
Table C1. Alternative-Fueled Vehicle Suppliers (Continued)

\begin{tabular}{|c|c|c|c|c|c|}
\hline State and Company Name & City & Contact & Phone & Operation Type & $\begin{array}{c}\text { Vehicle Fuel } \\
\text { Type }\end{array}$ \\
\hline Green Mountain Propane Gas Co. & Richmond & Jeff Fortune & (802) 434-6200 & & MD \\
\hline Norman's Automotive Srvc., Inc. & Springfield & Norman Canfield & (703) 451-9222 & CONVERTER & $\mathrm{HD} / \mathrm{CNG}$ \\
\hline \multicolumn{6}{|l|}{ VERMONT } \\
\hline Vermont Electric Car Co. & Middlesex & Hilton Dier III & (802) 223-6652 & CONVERTER & HD/LNG \\
\hline \multicolumn{6}{|l|}{ WASHINGTON } \\
\hline Energy Conversions, Inc. & Tacoma & Paul D. Jeusen & (206) 922-6670 & & LD/NG \\
\hline Gabriel Marine & Port Ludlow & Burton Gabriel & (360) $437-2136$ & OEM & $\mathrm{HD} / \mathrm{CNG}$ \\
\hline \multicolumn{6}{|l|}{ WISCONSIN } \\
\hline Krueger's Auto Tech Center & Cedarburg & Kevin Krueger & (414) 375-4555 & CONVERTER & HD/ALCOHOL \\
\hline Wisconsin Electric & Milwaukee & Gary Evans & (414) $221-3553$ & & MD \\
\hline Wisconsin Industrial Truck Co. & Milwaukee & Doug Wilson & (414) 466-9900 & CONVERTER & HD/CNG \\
\hline \multicolumn{6}{|l|}{ WEST VIRGINIA } \\
\hline Automotive Research Technology & Morgantown & Jody Stirewalt & (304) 291-2925 & CONVERTER & $\mathrm{HD} / \mathrm{CNG}$ \\
\hline Kleenair Systems, Inc. & Martinsburg & James M. Seibert & (304) 267-6441 & CONVERTER & $\mathrm{LD} / \mathrm{CNG}$ \\
\hline NAPA Autocare Center & Huntington & Larry Moore & (304) 525-3040 & CONVERTER & HD/ALCOHOL \\
\hline \multicolumn{6}{|l|}{ WYOMING } \\
\hline
\end{tabular}

CNG = Compressed natural gas.

$H D=$ Heavy duty.

$L D=$ Light duty.

LNG = Liquefied natural gas.

LPG $=$ Liquefied petroleum gas.

$M D=$ Medium duty.

$N A=$ Not applicable.

$\mathrm{NG}=$ Natural Gas.

OEM = Original Equipment Manufacturer.

Source: Energy Information Administration, Form ElA-886, "Alternative Fuel Vehicle Suppliers' Annual Report.” 

Appendix D

Alternative-FueledVehicles Made Available in 1995, Revised 


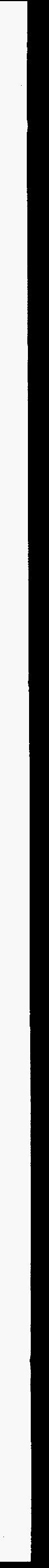


Table D1. Number of Onroad Alternative-Fueled Vehicles Made Available, by Fuel Type and Vehicle Configuration in 1995-Revised

\begin{tabular}{|c|c|c|c|c|c|c|c|}
\hline Fuel Type & Automobiles & $\begin{array}{c}\text { Passenger } \\
\text { Vans } \\
\end{array}$ & $\begin{array}{c}\text { Cargo } \\
\text { Vans/ } \\
\text { Pickups }\end{array}$ & $\begin{array}{c}\text { Other } \\
\text { Trucks }\end{array}$ & Buses & $\begin{array}{c}\text { Other } \\
\text { Onroad } \\
\text { Vehicles }\end{array}$ & Total \\
\hline Dedicated . . . . . . . . . . & 207 & 50 & 608 & W & 56 & W & 3,908 \\
\hline Nondedicated $\ldots \ldots \ldots \ldots \ldots$ & 576 & 159 & 2,053 & $W$ & 109 & W & 3,172 \\
\hline Dedicated . . . . . . . . . . . . & 136 & W & W & 27 & 404 & W & 1,508 \\
\hline Nondedicated $\ldots \ldots \ldots \ldots \ldots$ & 1,830 & 370 & $W$ & 715 & W & W & 8,784 \\
\hline Liquefied Natural Gas (LNG) . . . . . & 0 & 0 & $W$ & W & W & 0 & 85 \\
\hline Dedicated ................ & 0 & 0 & $w$ & W & W & 0 & 14 \\
\hline Dedicated ................ & 0 & 0 & 0 & 0 & 0 & 0 & 0 \\
\hline Nondedicated $\ldots \ldots \ldots \ldots \ldots$ & 1,335 & 0 & 0 & 0 & 0 & 0 & 1,335 \\
\hline Methanol, Neat (M100) . . . . . . . & 0 & 0 & 0 & 0 & 0 & 0 & 0 \\
\hline Dedicated ............... & 0 & 0 & 0 & 0 & 0 & 0 & 0 \\
\hline Nondedicated $\ldots \ldots \ldots \ldots \ldots$ & 0 & 0 & 0 & 0 & 0 & 0 & 0 \\
\hline Ethanol, 85 percent $^{a}$ (E85) $\ldots \ldots$. & 430 & 0 & 0 & 0 & 0 & 0 & 430 \\
\hline Dedicated $\ldots \ldots \ldots \ldots \ldots \ldots$ & 0 & 0 & 0 & 0 & 0 & 0 & 0 \\
\hline Nondedicated $\ldots \ldots \ldots \ldots \ldots$ & 430 & 0 & 0 & 0 & 0 & 0 & 430 \\
\hline Hybrid . . . . . . . . & W & $w$ & 5 & W & W & W & 11 \\
\hline Other $^{b}$ & 0 & 0 & 0 & 0 & 8 & W & 8 \\
\hline Dedicated. & 0 & 0 & 0 & 0 & 0 & 0 & 0 \\
\hline Nondedicated $\ldots \ldots \ldots \ldots \ldots$ & 0 & 0 & 0 & 0 & 8 & W & 8 \\
\hline Total & 4,589 & 955 & 8,218 & 3,965 & 1,150 & 906 & 19,783 \\
\hline Dedicated and Nonhybrid & 416 & 425 & 1,229 & 2,973 & 711 & 218 & 5,972 \\
\hline Nondedicated and Hybrid . . . . . . . & 4,173 & 530 & 6,989 & 992 & 439 & 688 & 13,811 \\
\hline
\end{tabular}

a'The remaining portion of 85-percent methanol and both ethanol fuels is gasoline.

${ }^{b}$ Includes hydrogen, biodiesel, and other altemative fuels.

$W=$ Withheld to avoid disclosure of individual company data.

Notes: - Vehicles made available are vehicles that are completed and made available for delivery to dealers or users in a given year. $\bullet$ Dedicated vehicles and nonhybrid electric vehicles are designed to operate exclusively on one alternative fuel. - Nondedicated vehicles and hybrid electric vehicles are configured to operate on more than one fuel, usually an alternative fuel and gasoline or diesel fuel. - Data are based on survey responses as of August 31, 1997.

Source: Energy Information Administration, Form ElA-886, "Alternative Fuel Vehicle Suppliers' Annual Report." 
Table D2. Number of Nonroad Alternative-Fueled Vehicles Made Available in 1995, by Fuel Type-Revised

\begin{tabular}{|c|c|}
\hline Fuel Type & 1995 \\
\hline Liquefied Petroleum Gas (LPG) . . . . . . . . & W \\
\hline Compressed Natural Gas (CNG) . ....... & 384 \\
\hline Liquefied Natural Gas (LNG) . . . . . . . & W \\
\hline Methanol, 85 percent $^{\mathrm{a}}$ (M85) $\ldots \ldots \ldots$ & 0 \\
\hline Methanol, Neat $(\mathrm{M} 100)$ & 0 \\
\hline Ethanol, 85 percent $^{\mathrm{a}}$ (E85) .. & 0 \\
\hline Ethanol, 95 percent $^{a}$ (E95) & 0 \\
\hline Electricity $\ldots \ldots \ldots \ldots \ldots$ & W \\
\hline Other $^{\mathrm{b}} \ldots$ & 0 \\
\hline
\end{tabular}

The remaining portion of 85-percent methanol and both ethanol fuels is gasoline.

Includes hydrogen, biodiesel, and other alternative fuels.

$\mathrm{W}=$ Withheld to avoid disclosure of individual company data.

Notes: - Nonroad vehicles are vehicles designed for offroad operation and used for industrial or commercial purposes. They include forklifts, agricultural and construction vehicles, and others. - Vehicles made available are vehicles that are completed and made available for delivery to dealers or users in a given year. Data are based on survey responses as of August 31, 1997.

Source: Energy Information Administration, Form EIA-886, "Alternative Fuel Vehicle Suppliers' Annual Report." 


\section{Glossary}

Aftermarket Conversion: A standard, conventionally fueled, factory-produced vehicle to which equipment has been added that enables the vehicle to operate on an alternative fuel.

Alcohols $\left(\mathrm{CH}_{3}-\left(\mathrm{CH}_{2}\right)_{n}-\mathrm{OH}\right)$ : The family name of a group of organic chemical compounds composed of carbon, hydrogen, and oxygen. The series of molecules vary in chain length and are composed of a hydrocarbon, plus a hydroxyl group (for example, methanol, ethanol, and tertiary butyl alcohol).

Aldehydes: One of several families of compounds formed as products of incomplete combustion in engines using gasoline, methanol, ethanol, propane, or natural gas as fuels. As a general rule of thumb, the presence of methanol or methyl ethers in the fuel will lead to formaldehyde as the primary aldehyde in the exhaust, while ethanol or ethyl ethers will lead to acetaldehyde as the primary aldehyde in the exhaust. In both cases, other aldehydes are present, but in much smaller quantities. Formaldehyde and acetaldehyde are toxic and possibly carcinogenic.

Alternative Fuel: As defined pursuant to the EPACT, methanol, denatured ethanol, and other alcohols, separately or in mixtures of 85 percent by volume or more (or other percentage not less than 70 as determined by DOE rule) with gasoline or other fuels, CNG, LNG, LPG, hydrogen, coal-derived liquid fuels, fuels other than alcohols derived from biological materials, electricity, or any other fuel determined to be substantially not petroleum and yielding substantial energy security benefits and substantial environmental benefits.

Alternative-Fueled Vehicle (AFV): A vehicle either designed and manufactured by an original equipment manufacturer or a converted vehicle designed to operate in either dual-fuel, flexible-fuel, or dedicated modes on fuels other than gasoline or diesel. This does not include a conventional vehicle that is limited to operation on blended or reformulated gasoline fuels.

Alternative-Fueled Vehicle Converter: An organization (including companies, government agencies, and utilities), or an individual who performs conversions involving alternative-fueleded vehicles. An AFV converter can convert (1) conventionally fueled vehicles to AFV's, (2)
AFV's to conventionally fueled vehicles, or (3) AFV's to another alternative fuel.

Barrel: A volumetric unit of measure for crude oil and petroleum products equivalent to 42 U.S. gallons.

Bi-Fuel Vehicle: A vehicle with two separate fuel systems designed to run on either an alternative fuel or conventional fuel using only one fuel at a time.

Biodiesel: Any liquid biofuel suitable as a diesel fuel substitute or diesel fuel additive or extender. A diesel substitute made from transesterification of oils of vegetables such as soybeans, rapeseed, or sunflowers (end product known as methyl ester) or from animal tallow (end product known as methyl tallowate). Biodiesel can also be made by transesterification of hydrocarbons produced by the Fisher-Tropsch process from agricultural byproducts such as rice hulls.

British Thermal Unit (Btu): A standard unit for measuring the quantity of heat energy equal to the quantity of heat required to raise the temperature of 1 pound of water by 1 degree Fahrenheit.

California Air Resources Board (CARB): A State regulatory agency charged with regulating the air quality in California. Air quality regulations established by the Board and often stricter than those set by the Federal Government.

Carbon Cycle: All reservoirs and fluxes of carbon; usually thought of as a series of the four main reservoirs of carbon interconnected by pathways of exchange. The four reservoirs, regions of the Earth in which carbon behaves in a systematic manner, are the atmosphere, terrestrial biosphere (usually includes freshwater systems), oceans, and sediments (includes fossil fuels). Each of these global reservoirs may be subdivided into smaller pools ranging in size from individual communities or ecosystems to the total of all living organisms (biota). Carbon exchanges from reservoir to reservoir by various chemical, physical, geological, and biological processes.

Carbon Dioxide $\left(\mathrm{CO}_{2}\right)$ : A colorless, odorless, nonpoisonous gas that is a normal part of the ambient air. Carbon dioxide is a product of fossil fuel combustion. 
Although $\mathrm{CO}_{2}$ does not directly impair human health, it is a greenhouse gas that traps the earth's heat and contributes to the potential for global warming.

Carbon Monoxide (CO): A colorless, odorless gas slightly lighter than air. It is poisonous if inhaled, in that it combines with blood hemoglobin to prevent oxygen transfer. It is produced by the incomplete combustion of fossil fuels with a limited oxygen supply (as in automobiles). It is a major component of urban air pollution, which can be reduced by the blending of an oxygenbearing compound such as alcohols and ethers into hydrocarbon fuels.

Chlorofluorocarbons (CFC's): A family of inert, nontoxic, and easily liquified chemicals used in refrigeration, air conditioning, packaging, and insulation, or as solvents or aerosol propellants. Because they are not destroyed in the lower atmosphere, they drift into the upper atmosphere where their chlorine components destroy ozone.

Clean Alternative Fuel: Any fuel (including methanol, ethanol, or other alcohols (including any mixture thereof containing 85 percent or more by volume of such alcohol with gasoline or other fuels), reformulated gasoline, diesel, natural gas, liquefied petroleum gases, and hydrogen) or power source (including electricity) used in a clean fuel vehicle that complies with the standards and requirements of the Clean Air Act Amendments of 1990.

Compressed Natural Gas (CNG): Natural gas compressed to a volume and density that is practical as a portable fuel supply (even when compressed, natural gas is not a liquid).

Carbon Monoxide Nonattainment Area: Areas with carbon monoxide design values of 9.5 parts per million or more (generally based on data for 1988 and 1989).

Converted Vehicle: A vehicle originally designed to operate on gasoline that has been modified or altered to operate on an alternative fuel.

Criteria Pollutant: A pollutant determined to be hazardous to human health and regulated under the Environmental Protection Agency's National Ambient Air Quality Standards. The 1970 amendments to the Clean Air Act require the Environmental Protection Agency to describe the health and welfare impacts of a pollutant as the criteria for inclusion in the regulatory regime.

Dedicated Vehicle: A vehicle designed to operate solely on one alternative fuel.

Diesel Fuel: A complex mixture of hydrocarbons with a boiling range between approximately 350 and 650 de Jrees Fahrenheit. Diesel fuel (simply referred to as "diesel") is composed primarily of paraffins and naphthenic compounds that auto-ignite from the heat of compression in a diesel engine. Diesel is used mainly by heavy-duty road vehicles, construction equipment, locomotives, and by marine and stationary engines.

Dual-Fuel Vehicle: A vehicle designed to operate on a combination of alternative fuel, such as CNG or LPG, and conventional fuel, such as gasoline or diesel. These vehicles have two separate fuel systems which inject both fuels simultaneously into the engine combustion chamber.

E85: A fuel containing a mixture of 85 percent ethanol and 15 percent gasoline.

E95:A fuel containing a mixture of 95 percent ethanol and 5 percent gasoline.

Energy Efficiency: The inverse of energy intensiveness: the ratio of energy outputs from a process to the energy inputs (for example, miles traveled per gallon of fuel).

Environmental Protection Agency (EPA): A government agency, established in 1970. Its responsibilities include the regulation of fuels and fuel additives.

Ethyl Tertiary Butyl Ether (ETBE), $\left(\mathrm{CH}_{3}\right)_{3} \mathrm{COC}_{2} \mathrm{H}_{3}$ A colorless, flammable, oxygenated hydrocarbon blend stock formed by the catalytic etherification of isobutylene with ethanol.

Ethanol $\left(\mathrm{C}_{2} \mathrm{H}_{5} \mathrm{OH}\right)$ : Otherwise known as ethyl alcohol, alcohol, or grain-spirit. A clear, colorless, flammable oxygenated hydrocarbon with a boiling point of 78.5 degrees Celsius in the anhydrous state. However, it forms a binary azeotrope with water, with a boiling point of 78.15 degrees Celsius at a composition of 95.57 percent by weight ethanol. It is used in the United States as a gasoline octane enhancer and oxygenate (10 percent concentration). Ethanol can also be used in high concentrations in vehicles optimized for its use.

Ether: The family name applied to a group of organic chemical compounds composed of carbon, hydrogen, and oxygen, and which are characterized by an oxygen atom attached to two carbon atoms (for example, methyl tertiary butyl ether).

Flexible-Fuel Vehicle: A vehicle with the ability to operate on alternative fuels (such as M85 or E85), 100 percent traditional fuels, or a mixture of alternative fuel and traditional fuels.

Global Warming: The theoretical escalation of global temperatures caused by the greenhouse effect. 
Greenhouse Effect: A popular term used to describe the roles of water vapor, carbon dioxide, and other trace gases in keeping the Earth's surface warmer than it would be otherwise. These radiatively active gases are relatively transparent to incoming shortwave radiation, but are relatively opaque to outgoing long wave radiation. The latter radiation, which would otherwise escape to space, is trapped by these gases within the lower levels of the atmosphere. The subsequent reradiation of some of the energy back to the Earth maintains the surface at temperatures higher than they would be if the gases were absent.

Greenhouse Gases: Those gases, such as water vapor, carbon dioxide, tropospheric ozone, nitrous oxide, and methane, that are transparent to solar radiation but opaque to long wave radiation. Their action is similar to that of increased humidity in a greenhouse.

Gross Vehicle Weight Rating: The weight of the empty vehicie plus the maximum anticipated load weight.

Heavy-Duty Vehicles: Pursuant to the EPACT, trucks and buses having a gross vehicle weight rating of 8,500 pounds or more.

Hydrogen $\left(\mathrm{H}_{2}\right)$ : The lightest of all gases, the element (hydrogen) occurs chiefly in combination with oxygen in water. It also exists in acids, bases, alcohols, petroleum, and other hydrocarbons.

Light- Duty Vehicles: Automobiles and trucks having a gross vehicle weight rating of less than 8,500 pounds.

Liquefied Natural Gas (LNG): Natural gas that has been refrigerated to temperatures at which it exists in a liquid state.

Liquefied Petroleum Gases (LPG): Propane, propylene, normal butane, butylene, isobutane, and isobutylene produced at refineries or natural gas processing plants (includes plants that fractionate raw natural gas plant liquids).

Lower Heating Value (LHV): The Btu content per unit of fuel excluding the heat from the condensation of water vapor in the fuel.

M85: A fuel containing a mixture of 85 percent methanol and 15 percent gasoline.

M100: 100 percent (neat) methanol.

Methane $\left(\mathrm{CH}_{4}\right)$ : The simplest of the hydrocarbons and the chief constituent of natural gas. Methane, a gas at normal temperatures and pressures, boils at -263 degrees Fahrenheit.

Methanol ( $\left.\mathrm{CH}_{3} \mathrm{OH}\right)$ : A colorless liquid with essentially no odor and very little taste. The simplest alcohol, it boils at 64.7 degrees Celsius. It is miscible with water and most organic liquids (including gasoline) and is extremely flammable, burning with a nearly invisible blue flame. Methanol is produced commercially by the catalyzed reaction of hydrogen and carbon monoxide. It was formerly derived from the destructive distillation of wood, which caused it to be known as wood alcohol.

Methyl Tertiary Butyl Ether (MTBE), $\left(\mathrm{CH}_{3}\right)_{3} \mathrm{COCH}_{3}$ : A colorless, flammable, liquid oxygenated hydrocarbon that contains 18.15 percent oxygen and has a boiling point of 55.2 degrees Celsius. It is a fuel oxygenate produced by reacting methanol with isobutylene.

Midwest Census Region: This U.S. Census Bureau region includes the following States: Illinois, Indiana, Iowa, Kansas, Michigan, Minnesota, Missouri, Nebraska, North Dakota, Ohio, South Dakota, and Wisconsin.

Mcf: Million cubic feet.

Motor Gasoline Blending of Oxygenates: Blending of gasoline and oxygenates under the Environmental Protection Agency's "Substantially Similar" Interpretive Rule (56 FR [February 11, 1991]).

Natural Gas: A mixture of hydrocarbon compounds and small quantities of various nonhydrocarbons existing in the gaseous phase or in solution with crude oil in natural underground reservoirs at reservoir conditions. The primary constituent compound is $\mathrm{CH}_{4}$. Gas coming from wells also can contain significant amounts of ethane, propane, butanes, and pentanes, and widely varying amounts of carbon dioxide and nitrogen. Pipeline-quality natural gas has had most, but not all natural gas liquids and other contaminants removed. On board a vehicle, it is stored under high pressure at 2,500 to 3,600 pounds per square inch (psi). A gallon of natural gas at 2,000 psi contains about $20,000 \mathrm{Btu}$; at $3,600 \mathrm{psi}$, a gallon contains about $30,000 \mathrm{Btu}$.

Neat Alcohol Fuels: Straight alcohol (not blended with gasoline) that may be either in the form of ethanol or methanol. Ethanol, as a neat alcohol fuel, does not need to be at 200 proof; therefore, it is often used at 180 to 190 proof ( 90 to 95 percent). Most methanol fuels are not strictly "neat," since 5 to 10 percent gasoline is usually blended in to improve its operational efficiency.

Nitrogen Oxides $\left(\mathrm{NO}_{x}\right)$ : Air-polluting gases contained in automobile emissions, which are regulated by the 
Environmental Protection Agency. They comprise colorless nitrous oxide $\left(\mathrm{N}_{2} \mathrm{O}\right)$ (otherwise known as dinitrogen monoxide, or as the anaesthetic "laughing gas"), colorless nitric oxide (NO), and the reddish-brown-colored nitrogen dioxide $\left(\mathrm{NO}_{2}\right)$. Nitric oxide is very unstable, and on exposure to air it is readily converted to nitrogen dioxide, which has an irritating odor and is very poisonous. Nitrogen dioxide contributes to the brownish layer in the atmospheric pollution over some metropolitan areas. Other nitrogen oxides of less significance are nitrogen tetroxide $\left(\mathrm{N}_{2} \mathrm{O}_{4}\right)$ and nitrogen pentoxide $\left(\mathrm{N}_{2} \mathrm{O}_{5}\right)$. Nitrogen oxides are sometimes collectively referred to as " $\mathrm{NO}_{x}$ " where " $x$ " represents any proportion of oxygen to nitrogen.

Nonattainment Area: A region that exceeds minimum acceptable National Ambient Air Quality Standards (NAAQS) for one or more criteria pollutants, in high population density areas, in accordance with the U.S. Census Bureau population statistics. Such regions (areas) are required to seek modifications to their State Implementation Plans, setting forth a reasonable timetable using means (approved by the Environmental Protection Agency) to achieve attainment of NAAQS by a certain date. Under the Clean Air Act, if a nonattainment area fails to attain NAAQS, the Environmental Protection Agency may superimpose a Federal Implementation Plan with stricter requirements or impose fines, construction bans, or cutoffs in Federal grant revenues until the area achieves applicable NAAQS.

Northeast Census Region: This U.S. Census Bureau region includes the following States: Connecticut, Maine, Massachusetts, New Hampshire, New Jersey, New York, Pennsylvania, Rhode Island, and Vermont.

Original Equipment Manufacturers (OEM's): Vehicle manufacturers that provide the original design and materials for assembly and manufacture of their product. They are directly responsible for manufacturing and modifying vehicles, making the vehicles commercially available, and providing a warranty for the finished product.

Oxygenated Fuel: Any fuel substance containing oxygen (includes oxygen-bearing compounds such as ethanol and methanol). Oxygenated fuel tends to give a more complete combustion of its carbon into carbon dioxide (rather than monoxide), thereby reducing air pollution from exhaust emissions.

Oxygenated Gasoline: Gasoline with an oxygen content of 1.8 percent or higher, by weight, that has been formulated for use in motor vehicles.
Ozone $\left(\mathrm{O}_{3}\right)$ : An oxygen molecule with 3 oxygen atoms that occurs as a blue, harmful, pungent-smelling gas at room temperature. The stratospheric ozone layer, which is a concentration of ozone molecules located at 6 to 30 miles above sea level, is in a state of dynamic equilibrium. Ultraviolet radiation forms the ozone from oxygen, but can also reduce the ozone back to oxygen. The process absorbs most of the ultraviolet radiation from the sun, shielding life from the harmful effects of radiation. Tropospheric ozone is normally present at the ground level in low concentrations. In cities where high levels of air pollutants are present, the action of the sun's ultraviolet light can, through a complex series of reactions, produce a harmful concentration of ozone in the air. The resulting air pollution is known as photochemical smog. Certain air pollutants (e.g., chlorofluorocarbons) can drift up into the atmosphere and damage the balance between ozone production and destruction, resulting in a reduced concentration of ozone in the layer.

Ozone Precursor: A chemical compound (such as nitrogen oxides, methane, nonmethane hydrocarbons and hydroxyl radicals) that, in the presence of solar radiation, reacts with other chemical compounds to form ozone.

Petroleum: A generic term applied to oil and oil products in all forms (such as crude oil, lease condensate, unfinished oil, refined petroleum products, natural gas plant liquids, and finished petroleum products).

Propane $\left(\mathrm{C}_{3} \mathrm{H}_{8}\right)$ : A normally gaseous straight-chain hydrocarbon, it is a colorless paraffinic gas that boils at a temperature of -43.67 degrees Fahrenheit. It is extracted from natural gas or refinery gas streams.

Reformulated Gasoline (RFG): Gasoline whose composition has been changed (from that of gasolines sold in 1990) to 1) include oxygenates, 2) reduce the content of olefins and aromatics and volatile components, and 3) reduce the content of heavy hydrocarbons to meet performance specifications for ozone-forming tendency and for release of toxic substances (benzene, formaldehyde, acetaldehyde, 1,3-butadiene, and polycyclic organic matter) into the air from both evaporation and tailpipe emissions.

Replacement Fuel: The portion of any motor fuel that is methanol, ethanol, or other alcohols, natural gas, liquefied petroleum gases, hydrogen, coal derived liquid fuels, electricity (including electricity from solar energy), ethers, or any other fuel the Secretary of Energy determines, by rule, is substantially not petroleum and would yield substantial energy security benefits and substantial environmental benefits. 
South Census Region: This U.S. Census Bureau region consists of the following States: Alabama, Arkansas, Delaware, District of Columbia, Florida, Georgia, Kentucky, Louisiana, Maryland, Mississippi, North Carolina, Oklahoma, South Carolina, Tennessee, Texas, Virginia, and West Virginia.

Tax Incentives: In general, a means of employing the tax code to stimulate investment in or development of a socially desirable economic objective without the direct expenditure from the budget of a given unit of government. Such incentives can take the form of tax exemptions or credits.
Tertiary Amyl Methyl Ether (TAME) $\left(\mathrm{CH}_{3}\right)_{2}\left(\mathrm{C}_{2} \mathrm{H}_{5}\right)$ $\mathrm{COCH}_{3}$ : An oxygenate blend stock formed by the catalytic etherification of isoamylene with methanol.

West Census Region: This U.S. Census Bureau region consists of the following States: Alaska, Arizona, California, Colorado, Hawaii, Idaho, Montana, Nevada, New Mexico, Oregon, Utah, Washington, and Wyoming. 